\title{
Changes in Barents Sea ice Edge Positions in the Last 440 years: A Review of Possible Driving Forces*
}

\author{
Nils-Axel Mörner ${ }^{1 \#, ~ J a n-E r i k ~ S o l h e i m ², ~ O l e ~ H u m l u m ³ ~}{ }^{3}$, Stig Falk-Petersen ${ }^{4}$ \\ ${ }^{1}$ Paleogeophysics \& Geodynamics, Stockholm, Sweden \\ ${ }^{2}$ Department of Physics and Technology, UiT The Arctic University of Norway, Troms $ø$, Norway \\ ${ }^{3}$ The University Centre on Svalbard (UNIS), Longyearbyen, Svalbard, Norway \\ ${ }^{4}$ The Fram Centre, Akvaplan-niva, Tromsø, Norway \\ Email: "morner@pog.nu
}

How to cite this paper: Mörner, N.-A., Solheim, J.-E., Humlum, O. and Falk-Petersen, S. (2020) Changes in Barents Sea ice Edge Positions in the Last 440 years: A Review of Possible Driving Forces. International Journal of Astronomy and Astrophysics, 10, 97-164. https://doi.org/10.4236/ijaa.2020.102008

Received: April 12, 2020

Accepted: June 6, 2020

Published: June 9, 2020

Copyright (c) 2020 by author(s) and Scientific Research Publishing Inc. This work is licensed under the Creative Commons Attribution International License (CC BY 4.0).

http://creativecommons.org/licenses/by/4.0/

\section{Open Access}

\begin{abstract}
This is the first report of the Barents Sea Ice Edge (BIE) project. The BIE position has varied between latitude $76^{\circ} \mathrm{N}$ and above $82^{\circ} \mathrm{N}$ during the last 440 years. During the period 10,000 to 6000 years ago, Arctic climate was significantly warmer than today. We review various oceanic and atmospheric factors that may have an effect on the BIE position. The Gulf Stream beat with respect to alternations in flow intensity and N-S distribution plays a central role for the changes in climate and BIE position during the last millennium. This occurred in combination with external forcing from total solar irradiation, Earth's shielding strength, Earth's geomagnetic field intensity, Earth's rotation, jet stream changes; all factors of which are ultimately driven by the planetary beat on the Sun, the Earth and the Earth-Moon system. During the last 20 years, we see signs of changes and shifts that may signal the end of the late $20^{\text {th }}$ century warm period. The BIE position is likely to start advancing southward in next decade.
\end{abstract}

\section{Keywords}

Barents Sea Ice Edge, Cyclic Changes, Gulf Stream Beat, Planetary-Solar Forcing

\section{Introduction}

Fluctuations of the southern sea ice edge and the Marginal Ice Zone in the Arctic Ocean in the North Atlantic occupy a key function for the understanding of ${ }^{*}$ Barents Sea Ice Edge (BIE).

${ }^{\#}$ Corresponding author. 
climate changes. The aim of this paper is to investigate a possible connection between the orbits of the planets and Earth's climate as documented in our revised 440 years long BIE position record. This is an old hypothesis, based on the complex synchronization structure of the solar system, which since Pythagoras of Samos (ca. 570 - 495 BC) is known as the music of the spheres [1]. As science evolved with Kepler's elliptical orbits and Newton's mechanics, and in particular with the discovery by Christian Huygens in the $17^{\text {th }}$ Century, that entrainment or synchronization between coupled oscillators requires very little energy exchange if enough time is allowed, the hypothesis of a connection is strengthened. Since the solar system is about 5 billion years old, there is plenty of time to synchronize.

Synchronization is observed in a large number of numerical relations in the solar system [2]. Since short periods may be washed out by stochastic noise in the climate system it is important to find long time series where the long periods may be preserved. In this paper we discuss what we can learn from a 440 years long series of estimated positions of Barents Sea Ice Edge (BIE).

In this series of papers, we present analysis of a revised data set, covering 440 years, of the estimated position of the late August ice edge position in the Barents Sea Ice Edge (BIE). The data set is unique in the sense that it covers the two last grand solar minima, the Maunder Minimum (1640-1720) and the Dalton Minimum (1790-1820) [3], the first one of which includes the coldest period of the last millennium in the Northern hemisphere (1690-1700) according to [4].

The Barents Sea Ice Edge (BIE) project was launched in 2015. The present paper, termed Paper 1, provides an introductory review of active variables and potential forcing functions. The second report, termed Paper 2, provides a more detailed analysis of correlations with other data sets and possible drivers of the BIE position variation.

The present paper begins with a general outline (Sections 2 and 3) of the geological and paleoclimatical background. The Gulf Stream plays a central role and is discussed in Section 4 with respect to its temporal and spatial variations during the last millennium. Section 5 discusses multiple integrated effects. Temperature and ice conditions during the Holocene are presented in Section 6. The life and resources in the Arctic including a graph of the BIE changes during the last 440 years are given in Section 7. Section 8 is devoted to a discussion of possible external driving forces. Section 9 covers internal coupling and feedback processes. The paper ends with a discussion in Section 10, and the conclusions drawn in Section 11.

\section{North Atlantic Ocean}

The opening of the North Atlantic Ocean began in the Early Eocene (e.g. [5] [6]). Mörner [7] gave a general account of the major Cenozoic events in the North Atlantic with respect to plate tectonics, crustal-lithospheric movements, paleoceanography and paleoclimatology. As stressed by Hopkins [8], the GIN Sea (i.e. the Greenland, Iceland and Norwegian Seas) "plays a unique and vital role in the 
circulation of the world's ocean, in coupling the Polar Sea (Arctic Ocean) to the Atlantic Ocean".

The rate of modern sea floor spreading is in the order of a couple of centimetres per year [9]. The Faroe-Iceland Ridge underwent a stepwise long-term subsidence ending in uplift in the Mid-Pleistocene [7]. The Fennoscandian Shield was suddenly uplifted at about the Oligocene/Miocene boundary around $23 \mathrm{Ma}$ $(\mathrm{Ma}=$ million years), initiating "The Baltic River" debouching in the Netherlands [7] [10] and slump deposits west of Svalbard [11] ending in a considerable subsidence of the Baltic region in the last million years. The Barents Shelf experienced uplift pulses at about $38 \mathrm{Ma}, 22.5 \mathrm{Ma}$ and 5 - $4 \mathrm{Ma}$, ending in a subsidence in the Mid-Pleistocene. Svalbard was uplifted at 22.5 Ma.

\section{Paleoclimate}

In the Paleocene to Eocene, Svalbard had a temperate climate [12] [13]. The temperate flora on Svalbard was originally assigned a Miocene age [14], which posed some paleoclimatological problems.

At about 3 - $4 \mathrm{Ma}$ (million year), the Panama Isthmus closed [7] [15] [16], which initiated the formation of the Gulf Stream bringing warm, high-salinity equatorial water to high latitudes in the North Atlantic (cf. below) and the Arctic cross-polar flow. By this, regional evaporation increased, especially from the ocean between Greenland, Svalbard and Norway, leading to increasing precipitation over the adjoining land areas, partly in the form of snow, resulting in significant glacier growth.

At about $3 \mathrm{Ma}$, there was a short period of quite temperate climatic conditions with a boreal forest in the Cape Copenhagen Formation of northeast Greenland. This period represents a global warm peak and global sea level high stand spanning the Kaena Reversed Geomagnetic Polarity zone within the Gauss Normal Polarity zone [17] [18].

At the Gauss/Matuyama boundary at about 2.6 Ma [17] [19] or rather at during Marine Isotope Stage (MIS) G10 at around 2.8 Ma [20] [21] [22] the alternation between continental glaciations and interglacials commenced. In Europe the sequence of continental glaciations started with the Pretiglian Glaciation at around the Gauss/Matuyama boundary and in the early Matuyama [7] [23] [24] [25]. Jakobsson et al. [26] presented a useful overview of the glacial history of the Arctic Ocean during the last 150,000 years. The probable impact from previous interglacials on our understanding of present-day climate conditions has been assessed by Kandiano et al. [27]. The deglaciation of the Barents Sea region is covered by [28] [29] [30].

\section{The Gulf Stream}

The Gulf Stream sets the character of the North Atlantic (e.g. [31] [32] [33]). From the Gulf of Mexico, the Gulf Stream follows the American east coast up to New Foundland where it turns east and splits into two main branches (Figure 1); 
the northern branch (known as the North Atlantic Drift) and the southern branch (known as the Canary Current). The northern branch (NB) reaches all the way up into the Barents Sea and the Arctic Ocean, making northwestern Europe mild and inhabitable. The southern branch (SB) affects the Gibraltar area, northwest Africa and the Canary Islands.

When the warm Gulf Stream water in the North Atlantic Drift meets the cold polar water in the Norwegian Sea and in the Labrador Sea, it sinks forming the North Atlantic Deep Water, which is a part of the huge global thermohaline circulation system (Figure 2). This is a global system of surface water circulation and deep-water circulation. According to [34] "heat and freshwater fluxes at the ocean's surface play a key role in the forming of ocean currents, which in turn

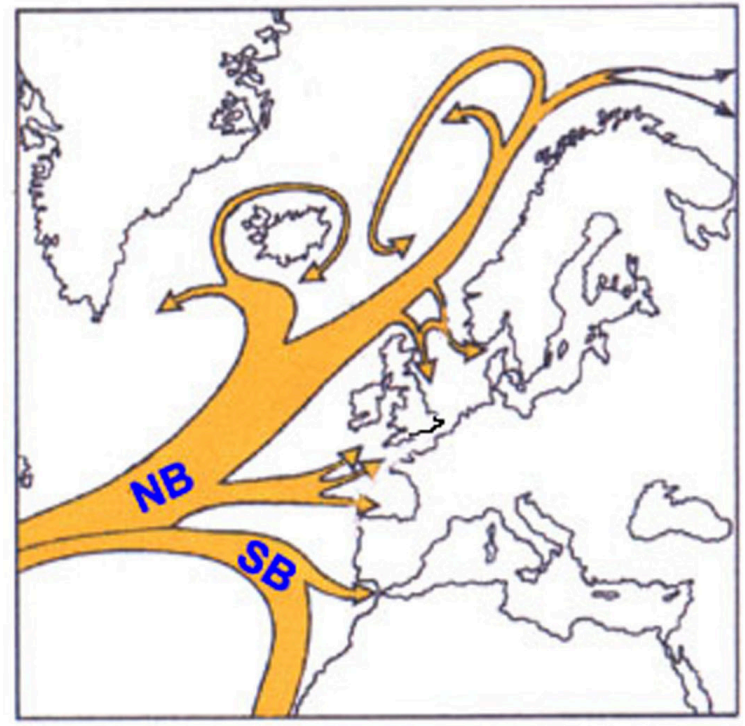

Figure 1. The Gulf Stream and its division into a northern (NB) and southern (SB) branch.

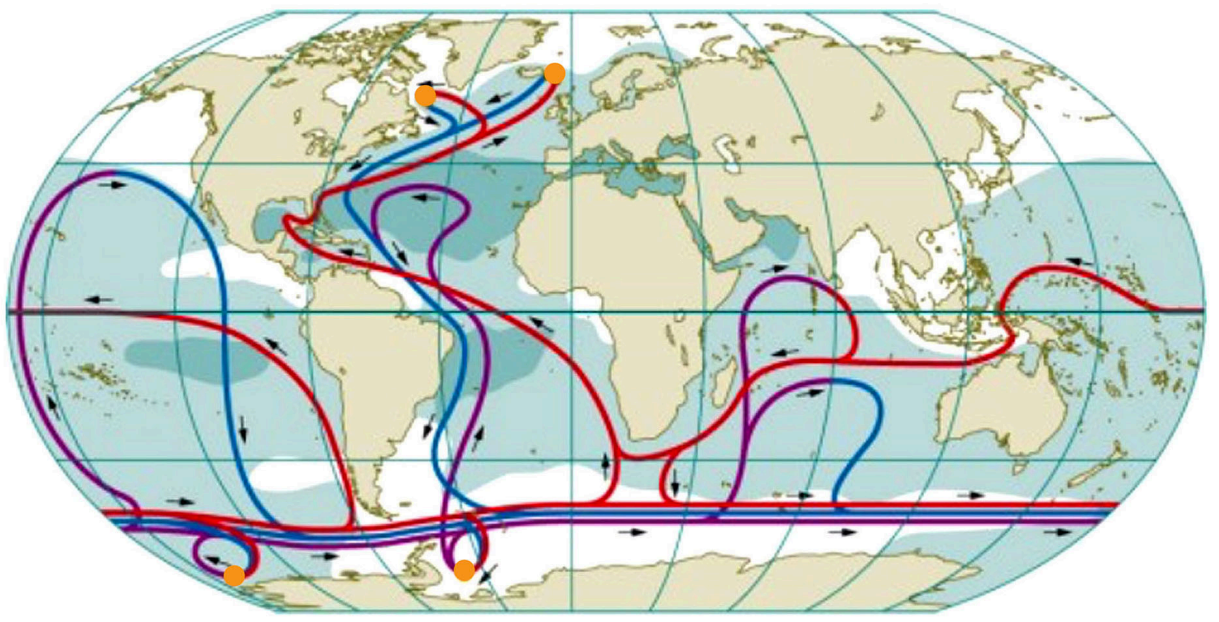

Figure 2. The global thermohaline circulation system with the approximate areas of down-welling of warm surface water into cold deep water in the Arctic and Antarctic marked by orange dots (modified from [35]). 
have major effect on climate" and he finishes by concluding: "understanding its past and future behaviour is crucial to our understanding of climate change". This is, of course, exactly the reason why we have undertaken the present study of the ice edge behaviour and its forcing functions.
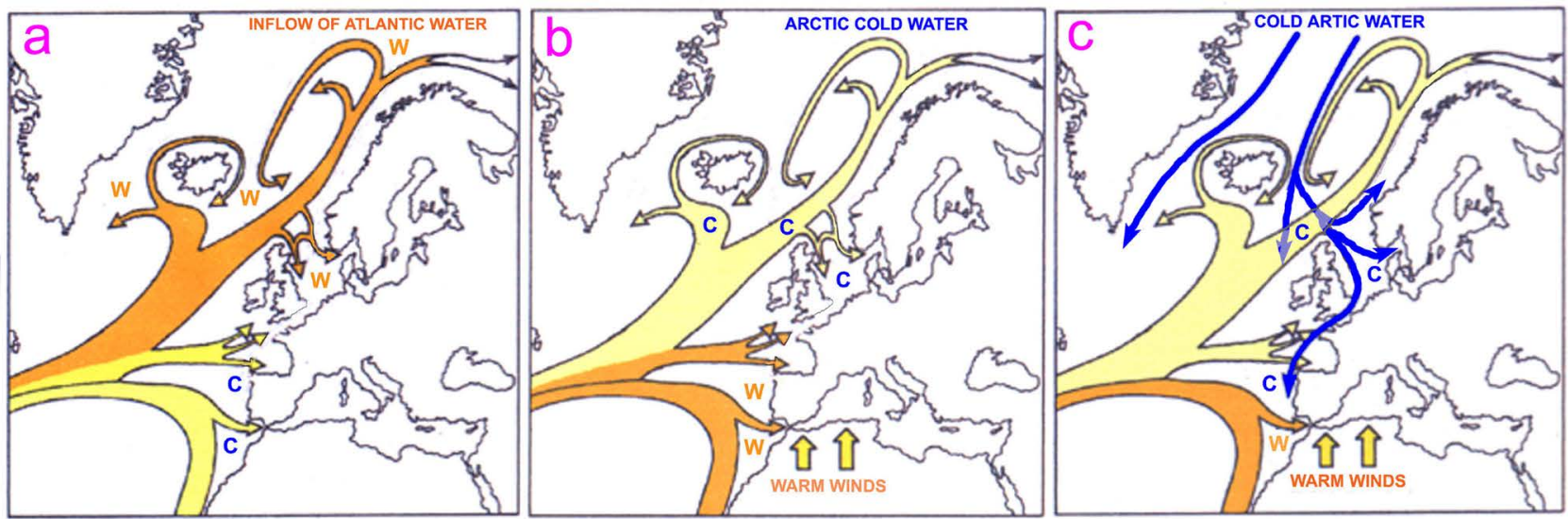

Figure 3. The beat (pulsation) of the Gulf Stream as a function of changes in the Earth's rate of rotation [36] [37] redistributing ocean water masses and ocean stored heat along the northern (a) and southern (c) branches of the Gulf Stream. The type-a circulation is typical for Grand Solar Maxima, and the type-c (and type-b) is typical for Grand Solar Minima.

\section{The Gulf Stream Beat}

The Gulf Stream splits at about $40^{\circ} \mathrm{N}$ Lat. and $30^{\circ} \mathrm{W}$ Long. into a northern branch (NB) and a southern branch (SB) as illustrated in Figure 1. The distribution of oceanic water along those two branches is not constant with time but subjected to a "beat" or pulsation in its intensity and especially in the alternation of water distribution along the two branches [36] [37] [38] as illustrated in Figure 3. When the northern branch increases in intensity and warms Scandinavia and the Arctic, the southern branch decreases and cools the Gibraltar-Canary area (Figure 3(a)). When southern branch increases and warms the Gibraltar-Canary region, the northern branch decreases and Scandinavia and the Arctic cools (Figure 3(b) \& Figure 3(c)). The forcing of the alternations in beat along the northern and southern branches comes from changes in Earth's rate of rotation [36] [37]; deceleration in the first case (Figure 3(a)) and acceleration in the second case (Figure $3(\mathrm{c})$ )).

The type-a circulation is typical for Grand Solar Maxima and is recorded at the known warm peaks at about $\mathrm{AD} \sim 970, \sim 1250, \sim 1320, \sim 1590-1600, \sim 1720$ 1790 , and after 1900. The type-b and type-c circulations are typical for Grand Solar Minima and is well recorded and documented at the "little ice ages" around $\mathrm{AD} \sim 1050, \sim 1300, \sim 1450, \sim 1690, \sim 1810$, and there are strong reasons to expect that it will re-occur at about AD 2040 [37] [38] [39].

The alternations between type-a and type-c circulation have wide environmental effects in the North Atlantic. Significantly, Yasuhara et al. [40] find a correlation between cooling events and periods of reduced Atlantic Meridional Overturning Circulation (AMOC) during the last 10,000 years, Thibodeau et al. [41] between the Little Ice Age and a slowdown of the North Atlantic circulation, and 
Seidov et al. [42] for the last 60 years.

Grand Solar Maxima and Minima affect the Earth's shielding capacity as a function of the Solar Wind interaction with the Earth's geomagnetic field (e.g. [43]). The shielding controls the penetration of particles responsible for the formation of ${ }^{14} \mathrm{C}$ in the atmosphere, the atmospheric ${ }^{10} \mathrm{Be}$ content and cosmic ray particles [44]. The variations in atmospheric ${ }^{14} \mathrm{C}$ content are well documented and provide a continual record of the variations in Solar Wind intensity and its effect on the Earth's geomagnetic field strength as recorded by the changes in Earth's shielding capacity [37] [38] [45].

Figure 4 gives the changes in ${ }^{14} \mathrm{C}$ production during the last millennium (redrawn from [46]). Weak shielding and high ${ }^{14} \mathrm{C}$ production are shown downwards with the names of the Grand Solar Minima given in blue. During these periods the North Atlantic experienced type-c (or b) circulation (Figure 3). Strong shielding and low ${ }^{14} \mathrm{C}$ production (upwards) occurred when the Sun experienced Grand Solar Maxima and the North Atlantic had a type-a circulation (Figure 3). Filtering of the ${ }^{14} \mathrm{C}$ production curve (red line in Figure 4) gives a main period of 210 years (grey line in Figure 4), which corresponds to the main solar cycle identified by Abreu et al. [47] for the last 9400 years.

Easterbrook [44] [48] has documented a close correlation between Grand Solar Minima (Wolf, Spörer, Maunder, Dalton, 1880-1915, 1945-1977) and climatic records of severe cooling events. Mörner [37] showed that the Spörer, Maunder and Dalton Minima are very clearly identified in ocean temperature records indicating type-c circulation (Figure 5). Even the 1930-1940 warming in the north and cooling in the south were followed by a cooling in the north and a warming in the south (Fig. 9 in [37]) indicates a change from type-a to type-b/c circulation.

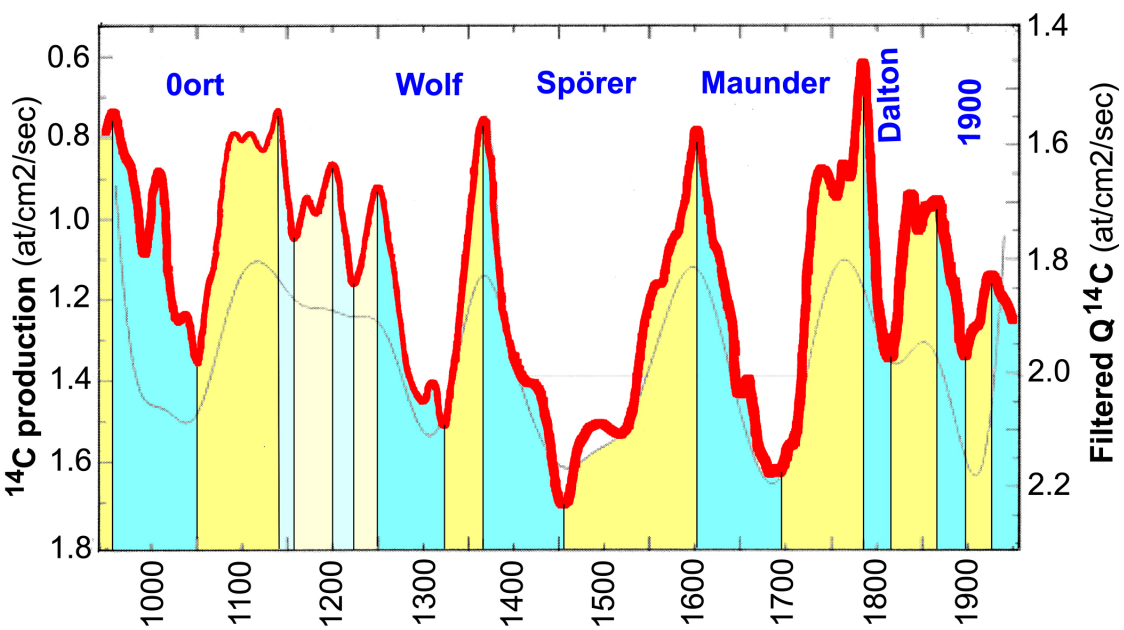

Figure 4. Changes in ${ }^{14} \mathrm{C}$ production in the atmosphere (red curve) $950-1950$ as a function of the Solar Wind induced changes in Earth's shielding capacity (strongly modified from [46]). Blue fields mark decreased shielding trends and proposed cooling periods of grand solar minima. Yellow fields mark increasing shielding trends and proposed warming periods of grand solar maxima. The 1970-2000 warming is missing because the records end in 1950. The thin grey line shows a filtering period of $\sim 210$ years with scale to the right. 

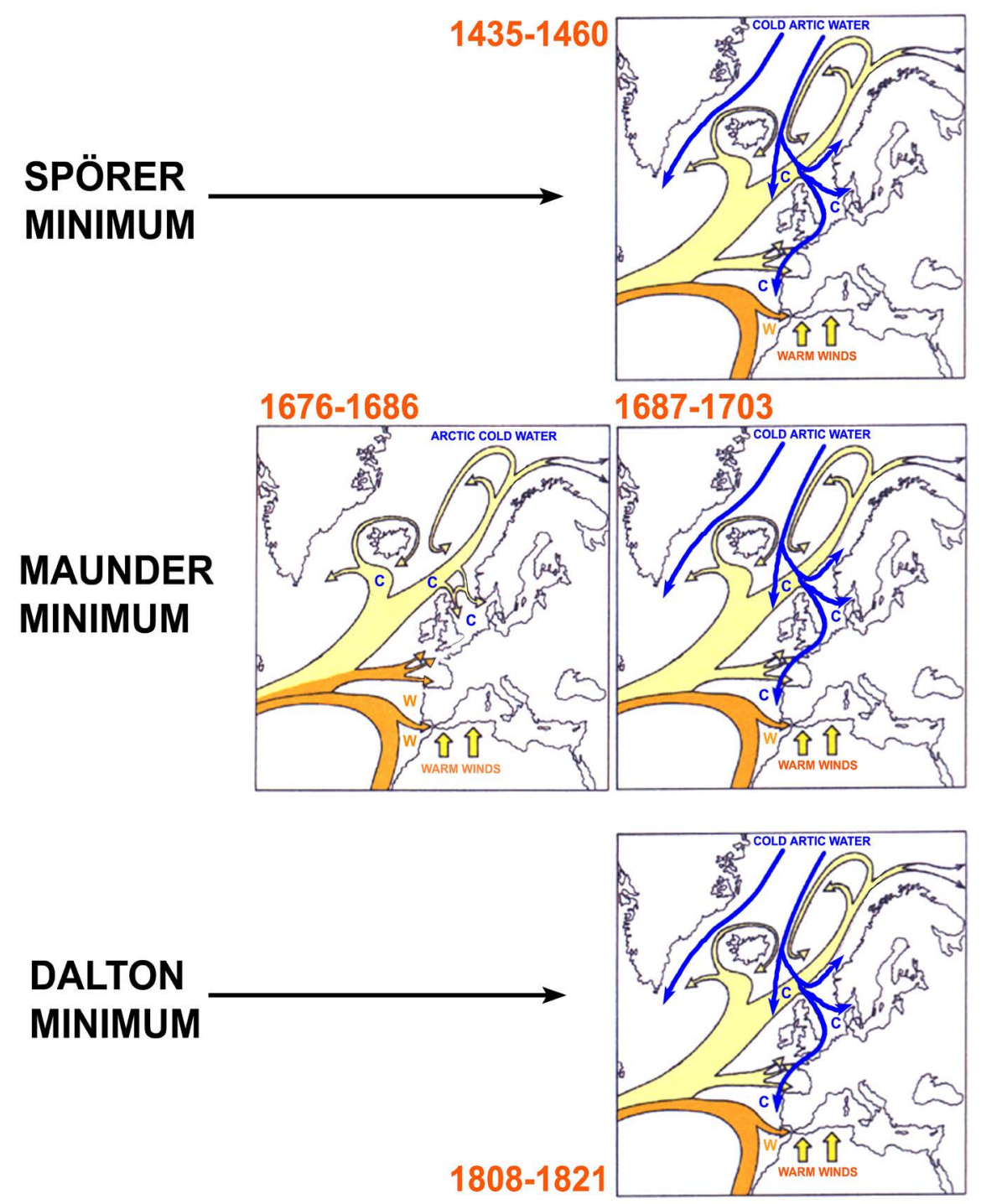

Figure 5. Ocean circulation and Gulf Stream beat during the Spörer (type-c), Maunder (type-b followed by type-c) and Dalton (type-c) Grand Solar Minima (from [37]). Data in orange refer to the time of temperature changes recorded in the database used by Mörner [37].

Figure 4 suggests that the Medieval Warm Optimum may have lasted from 1050 to 1250 , which is significantly longer than originally proposed by Lamb (e.g. [49]).

The period $\mathrm{AD} 950$ - 1050 is an interesting and important period. It is well covered in Figure 4 with a warm peak around 970 and a cold peak around 1050 (the Oort Grand Solar Minimum in Figure 4). In Sweden, the late $10^{\text {th }}$ century was warm and the early $11^{\text {th }}$ century cool and exceptionally dry with sand drift and dying peat bogs over in northern Europe. Figure 6 illustrates the situation in Greenland [50] [51]. In the period AD 900 - 1000, quite warm climatic conditions prevailed and there was a free sailing route from Iceland to Greenland. Already a century later icebergs and sea ice prevented a direct route to Greenland, 
and the sailing route was displaced to the south. This was just in the time of the Oort Grand Solar Minimum (Figure 4). By AD 1200 - 1400 the sailing route was even more displaced to the south, and the Viking settlements on Greenland were left to become extinct. Obviously, this was due to the cooling events during the Wolf and Spörer Grand Solar Minima.

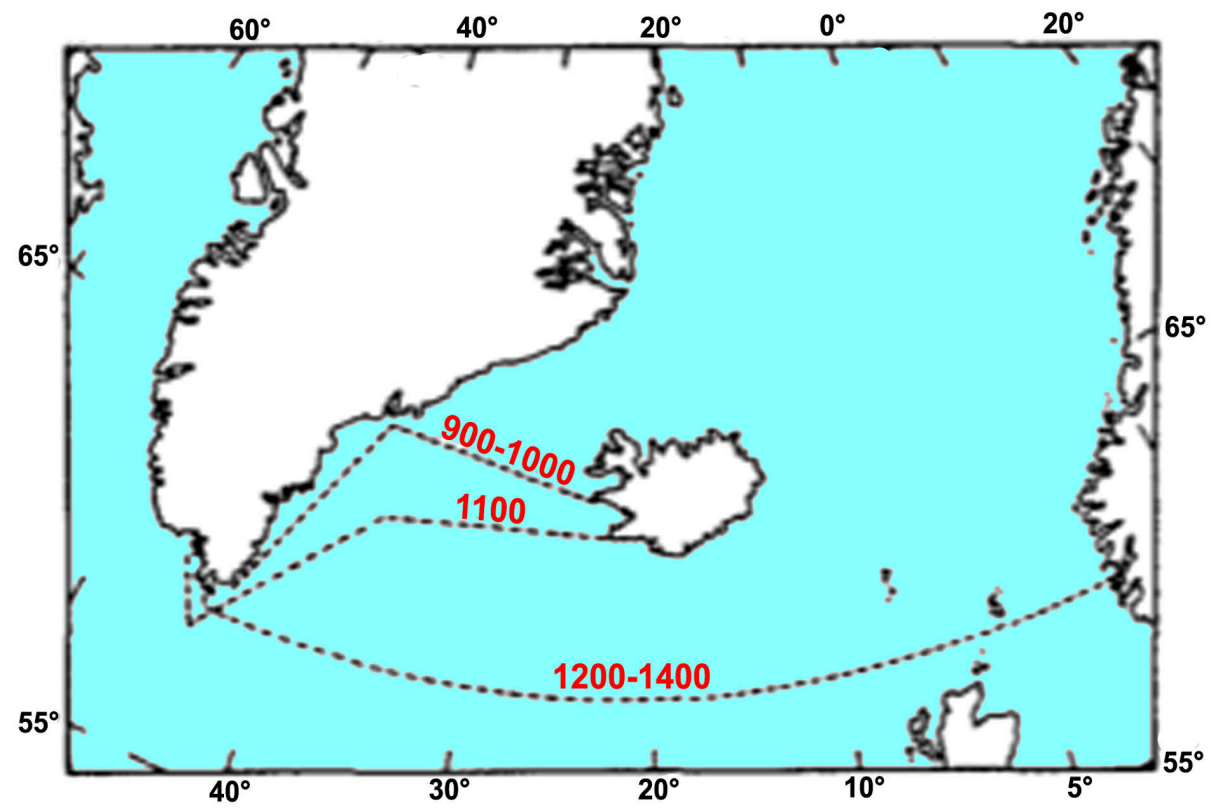

Figure 6. The changes in sailing route to Greenland as a function of changes in climate and ocean circulation (modified from [50] [51]).

Isotopic data from the GISP2 ice core suggest multi-year intervals of low temperature especially in the early and mid- $14^{\text {th }}$ century, presumably representing the coldest period in central Greenland for the last 700 years [52], among other things exposing the remaining Norse settlement in Greenland to disaster [53]. The growth of open system pingos in Disko Island (central W Greenland) also points towards multi-year cold intervals during the Little Ice Age [54] [55]. Analysis of the isotopic composition of ice samples from a Little Ice Age glacier-derived rock glacier in Disko Island [56] indicate a mean annual air temperature about $2^{\circ} \mathrm{C}-4^{\circ} \mathrm{C}$ below present values, presumably reflecting net ice accumulation during a cold interval of the Little Ice Age, tentatively dated to $\mathrm{AD}$ $1600-1775$.

The drift-ice records of Bond et al. [57] [58] and "deglacial oscillations in ocean circulation" [59] seem directly to add on to the Gulf Stream beat picture of Mörner [37]. Cores from both sides of the North Atlantic (off Newfoundland and off Ireland) record cyclic peaks in ice-rafted material from drift-ice (IRD), indicating cyclic alternations between two modes: 1) low IRD, warmer SST and a circulation as today (i.e. the type-a circulation of Figure 3), and 2) ice-rafting events with peaks in IRD, colder SST and a significant southward advection of colder and fresher water (i.e. the type-c circulation of Figure 3). As a conse- 
quence, the thermohaline circulation was reduced [57] [60]. This is consistent with the model of Mörner [51], where the surface water circulation affects the deep-water circulation, not vice versa as illustrated in Figure 7. Furthermore, this southward shift of colder, ice-bearing surface water far into the sub-polar North Atlantic had an ocean surface circulation origin, which was coupled with the atmospheric circulation over Greenland [57]. Consequently, we can safely assume that the observed cooling events recorded far south along the European coasts (Figure 3(c)) also extended over the central and western parts of the North Atlantic (as recorded by the drift-ice events). The correlation by Bond et al. [58] between periods of increased drift-ice and periods of reduced Solar activity (as recorded by cosmogenic nuclides which, in fact, refers to Solar Wind activity [38], not irradiance as claimed by Bard et al. [61] and Sejrup et al. [62]. This implies that the Gulf Stream pulses must represent Solar Wind effects on the Earth's total rate of rotation as proposed by Mörner [36] [37] [43] [63] [64]. The presence of an external rotational pulse was recently endorsed by [65].

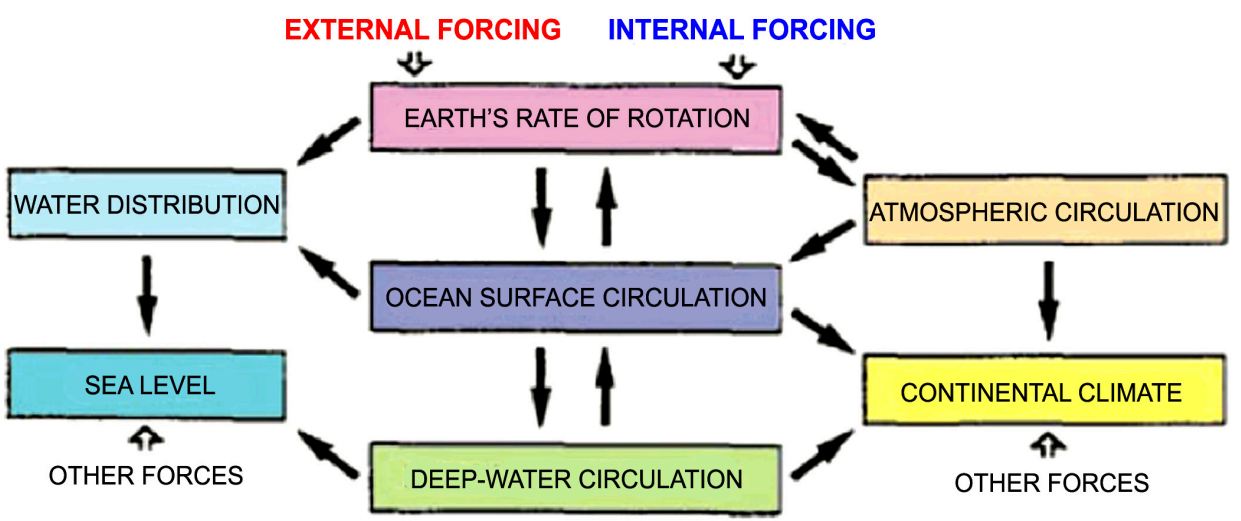

Figure 7. Effects and feedback interaction of changes in Earth's rate of rotation (from [51]). Ocean surface circulation plays the dominant role in redistribution ocean-stored energy (as recorded by paleoclimate) and water masses (as recorded by sea level). The external forcing refers to the planetary beat on the Sun, the Earth and the Earth-Moon system [36] [43] [63]. Internal forcing comes from the redistribution of mass and the changes in Earth's radius due to changes in sea level [66] [67] [68].

Kerr [69] wrote about "a slow, multidecadal climate pulse that beats the Atlantic Ocean" (his AMO) and noted that already Bjerknes [70] wrote about "a surge of warm water up the Gulf Stream" in order to explain the early 20-century's warm climate over Northwest Europe. Similarly, the North Atlantic changes recorded by Levitus [71] had to be related to changes in the strength of the Gulf Stream. Furthermore, the major shifts in climate and sea level recorded over the last 150 years in Northwest Europe correspond with the major shifts in LOD (length of the day) [67] [68], indicating an interaction between rotation and Gulf Stream beat. In the Florida Straits, the water masses transported by the Florida Current (28 - $32 \mathrm{~Sv}$ ) varied significantly through the last millennium with a general lowering of about $3 \mathrm{~Sv}$ during the "Little Ice Age" [72]. 

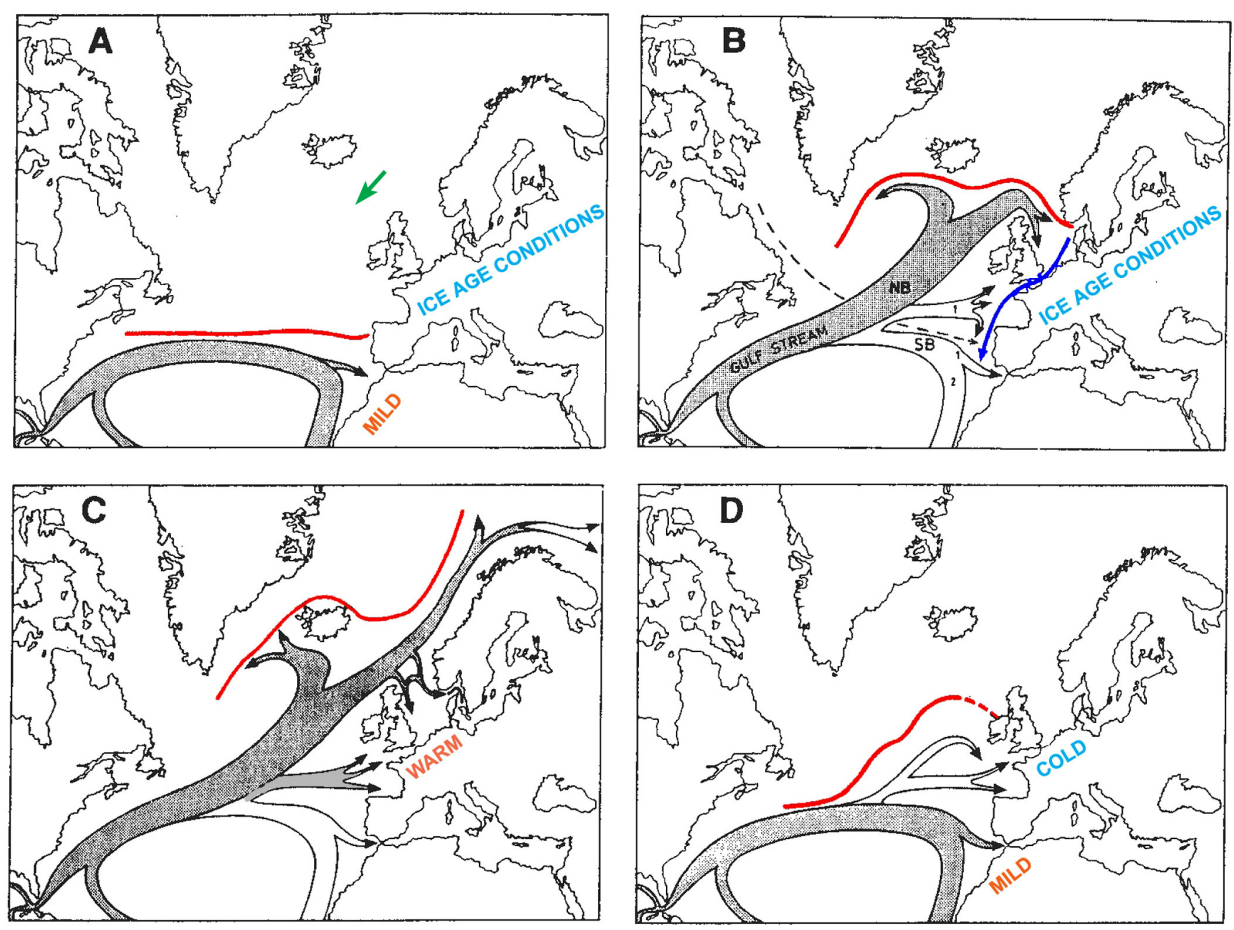

Figure 8. Changes in polar front position (red lines) and Gulf Stream distribution (hatched flow arrows) during the main stadials and interstadials of the last $25 \mathrm{Ka}$ (thousand years): (A) at LGM, (B) at $18 \mathrm{Ka},(\mathrm{C})$ at $14-16 \mathrm{Ka}$ and (D) at $12-13 \mathrm{Ka}$ (modified from [68]).

In Figure 8, we compare the polar front positions and Gulf Stream distribution at the major stadial/interstadial changes of the last $25 \mathrm{Ka}$ (from [68]); viz. at LGM (Last Glacial Maximum, 22 - $24 \mathrm{Ka}$ ), the $18 \mathrm{Ka}$ glacial maximum, the Bölling/Alleröd (BÖ/AL) interstadials at about $16-14 \mathrm{cal}$. Ka BP and the Younger Dryas (YD) stadial at around $13-12 \mathrm{cal}$. Ka BP (Ka BP = thousand years before present).

During LGM the land ice had its maximum expansion and the polar front was located far down in the North Atlantic forcing the Gulf Stream along its southern branch (Figure 8(A)). In the Pacific, the Kuroshio Current was forced to lower latitudes as a function of a considerable speeding-up of Earth's rate of rotation due to the sea level lowering and decrease in Earth's radius [36] [68]; i.e. internal forcing (Figure 7). On the Faroe shelf, grooves and furrows from grounded icebergs have been recorded at several $100 \mathrm{~m}$ depth indicating drift from the NE to the SW of polar water full of floating icebergs, some of which must have been of gigantic size to scratch the seafloor as deep down as $300-500 \mathrm{~m}$ [73] (green arrow in Figure 8(A)).

At the Pomeranian Stadial around $18 \mathrm{Ka}$, the polar front was just south of Iceland. The Gulf Stream seems to have penetrated up to the edge of this front (Figure 8(B)).

During the Bölling-Alleröd Interstadials, the Gulf Stream penetrated all the way up into the Barents Sea (Figure $8(C)$ ). A boreo-arctic mollusc fauna entered the North Sea and the Kattegatt. At the Younger Dryas Stadial the climatic con- 
ditions returned to arctic and glacial conditions. The polar front and the Gulf Stream were displaced to the south (Figure $8(D)$ ). This was also the case with the Kuroshio Current in the Pacific [36] [66] indicating increasing rate of Earth's rotation. The drastic changes in ocean water distribution, climate and rotation in association with the $\mathrm{BÖ} / \mathrm{AL}$ to YD periods pose complicated forcing [68] [74].

\section{Multiple and Integrated Effects}

The changes in ice edge positions within the Svalbard and Greenland regions during the last $400-500$ years-the topic of this project-must be the function of multiple variables (e.g. Bucha [75] [76]; Kellogg [77]; Dickson et al. [78]; Forman et al. [79]; Humlum [56] [80]; Jennings et al. [81]; Meeker and Mayewski [82]; Vinje and Goosse [83]; Soon [84]; Divine and Dick [85]; Yndestad [86]; Humlum et al. [87] [88]; Sejrup et al. [62] [89]; Davis and Brewer [90]; Solheim et al. [91]; Yndestad and Solheim [92]; Roy [93]; Årthun et al. [94]). Because the Gulf Stream beat records a close correlation with the Grand Solar Maxima/Minima alternations (above), there are reasons to consider the multiple effects of the planetary beat on the Sun, the Earth and the Earth-Moon system as illustrated in Figure 9 (from [43]). The observed changes in Gulf Stream beat, North Atlantic Oscillation (NAO), Pacific Multidecadal Oscillation (PDO), other oceanic "oscillations" system and the new concept of rotational eustasy seem to lead their origin in processes within Figure 9 system [64].

Ocean circulation changes as presented in Figure 9 imply that the observed data may record planetary cycles (e.g. [1]), solar cycles (e.g. [92]), lunar-solar tidal cycles (e.g. [90] [95]) and lunar cycles [86] [96].

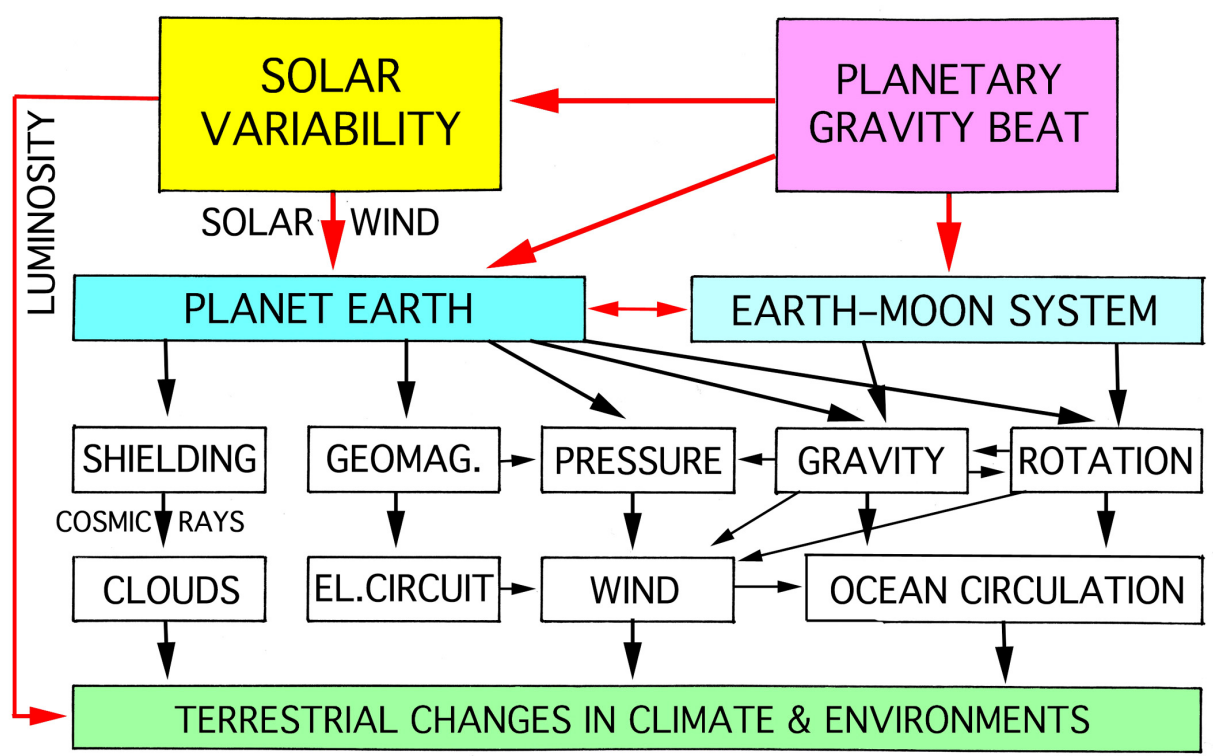

Figure 9. Integrated effects of planetary beat on solar variability in luminosity (e.g. electromagnetic radiation) and, via the Solar Wind, on a number of fundamental terrestrial processes, and, via direct effects on the Earth-Moon system, on gravity, rotation, wind, ocean circulation, and sea level changes and oceanic oscillation systems [43] [63] [64]. 


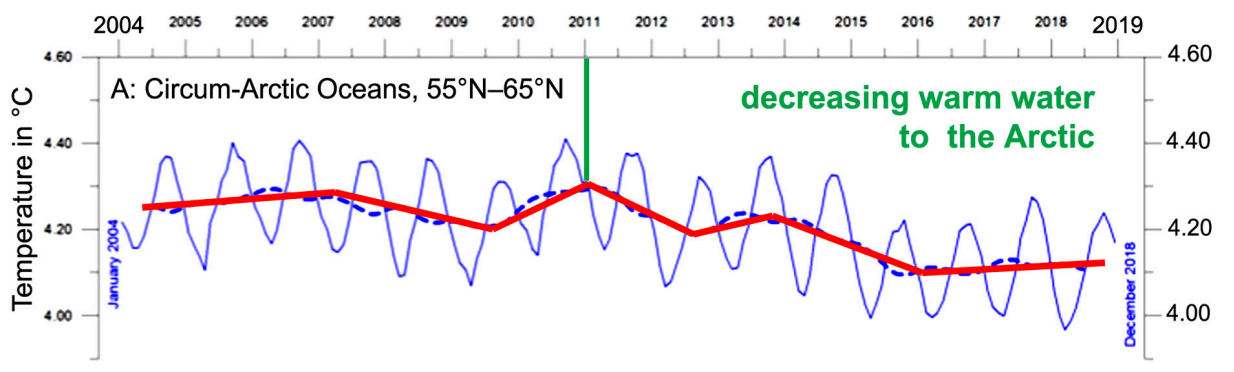

Latidude $30^{\circ} \mathrm{N}$

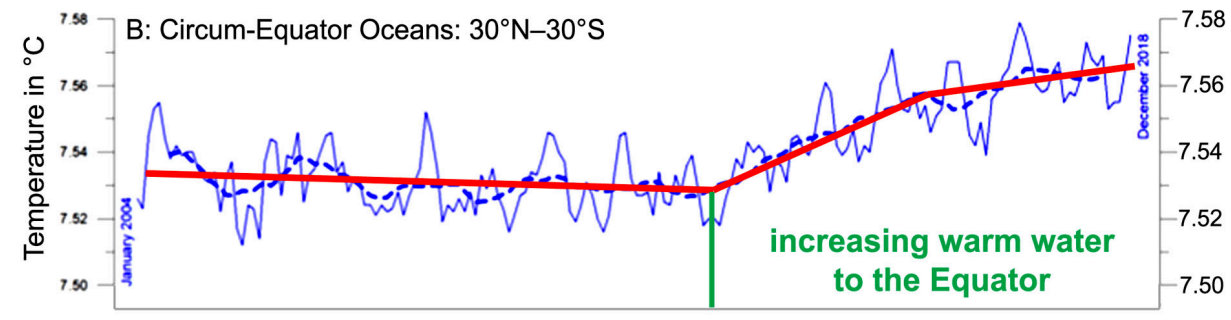

(A)

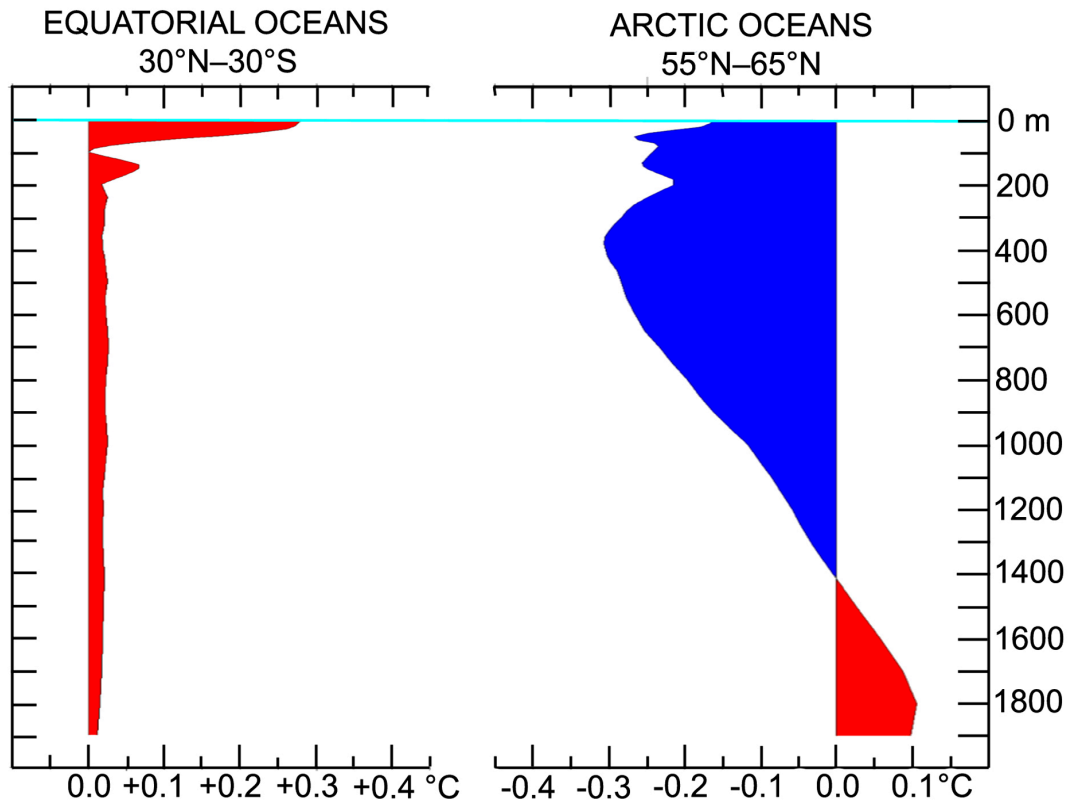

(B)

Figure 10. (A) Global ocean temperature 0 - $1900 \mathrm{~m}$ according the Argo measurements (reworked from [97]) indicating the redistribution of ocean surface water between the Arctic and the Equatorial regions as proposed by Mörner [37] [38]. The alternating trend may be a signal for the transition between type-a and type-b/c circulation. (B) Argo temperature changes $\left({ }^{\circ} \mathrm{C}\right)$ 2004-2019 [97] [98]. Whilst the Arctic Oceans were cooling (down to $1300 \mathrm{~m}$ ), the Equatorial Oceans were worming (in their uppermost $50-100 \mathrm{~m}$ ).

A recent manifestation of the Gulf Stream beat (i.e. the alternations between type-a and type-b/c circulation in Figure 3) and the concept of rotational eustasy [94] seems to be recorded in the ocean temperature variations between the Arctic from 2011 and the equatorial regions from 2012 as illustrated in Figure 10 (A). 
The Argo temperature changes with depth from 2004 to 2019 [97] demonstrate that the Arctic Oceans were cooling considerably in the upper $1300 \mathrm{~m}$ at the same time as the Equatorial Ocean were warming in the upper $50-100 \mathrm{~m}$ (Figure 10(B)). This is consistent with a decrease in the northern branch of the Gulf Stream (i.e. a change from type-a towards a type-b or type-c circulation; Figure 3), and a decrease in the Arctic down-welling and thermohaline circulation (Figure 2). The Arctic cooling recorded is likely-if continued (cf. Figure $10(\mathrm{~A}))$ - to initiate a southward advance of the BIE position in the near future.

The temperature changes shown in Figure 10(A) and Figure 10(B) are linked to a considerable freshening of the North Atlantic after 2012 as excellently shown by Holliday et al. [99]. Their analysis is based on the Argo measurements, too. According to them, the freshening was both rapid and extensive, and reached a low salinity level not recorded before in the last 120 years.

The concept of Gulf Stream beat [37] and the observations of latitudinal changes in temperature in the North Atlantic (Figure 10(A) and Figure 10(B) at about 2011 has recently got an important support in observed changes in northward ocean heat transport and cooling (about $2^{\circ} \mathrm{C}$ ) and freshening in the Eastern Subpolar Gyre [100], which may be taken to signify the onset of a general change from type-a to type-c circulation.

Another important implication of Figure 9 scheme is that the solar impact on planet Earth primarily goes via heliomagnetic Solar Wind emission and not via total solar irradiance (TSI). When changes in the Earth's geomagnetic shielding capacity are involved, we can be sure that the main forcing function comes from the Solar Wind interaction with the magnetosphere and the Earth's rate of rotation (Figure 9). Therefore, observed variations in ${ }^{14} \mathrm{C}$ and ${ }^{10} \mathrm{Be}$ are the manifestation of changes in the shielding capacity (Solar Wind) not in TSI (as proposed by, for example, Bard et al. [61], Scafetta [1], and Veretenenko and Ogurtsov [101]). The so-called 60-yr cycle [102] must primarily be a function of heliomagnetic Solar Wind emission [43] [63].

\section{Temperature and Ice Conditions during the Holocene}

The Last Glaciation ended at about 11,800 BP, which is the boundary between the Pleistocene and the Holocene and also the boundary between the Younger Dryas and the Preboreal. The warming following the last glaciation at the end of the Younger Dryas period $11.8 \mathrm{Ka}$ ago was abrupt. In central Greenland, temperatures increased by $7^{\circ} \mathrm{C}$ or more within 10 - 30 years [103] [104] [105]. Most of the changes in wind-blown materials, snow and some other climate indicators registered by ice cores, including a doubling of snow accumulation, played out within a few years [106].

In the Northern Hemisphere, summer insolation peaked 10 - $9 \mathrm{Ka}$ ago when the last remnants of the large ice sheets in the northern hemisphere retreated rapidly. At that time the incoming solar radiation was approximately $8 \%$ greater than at present [107]. This may have been especially significant at high latitudes 


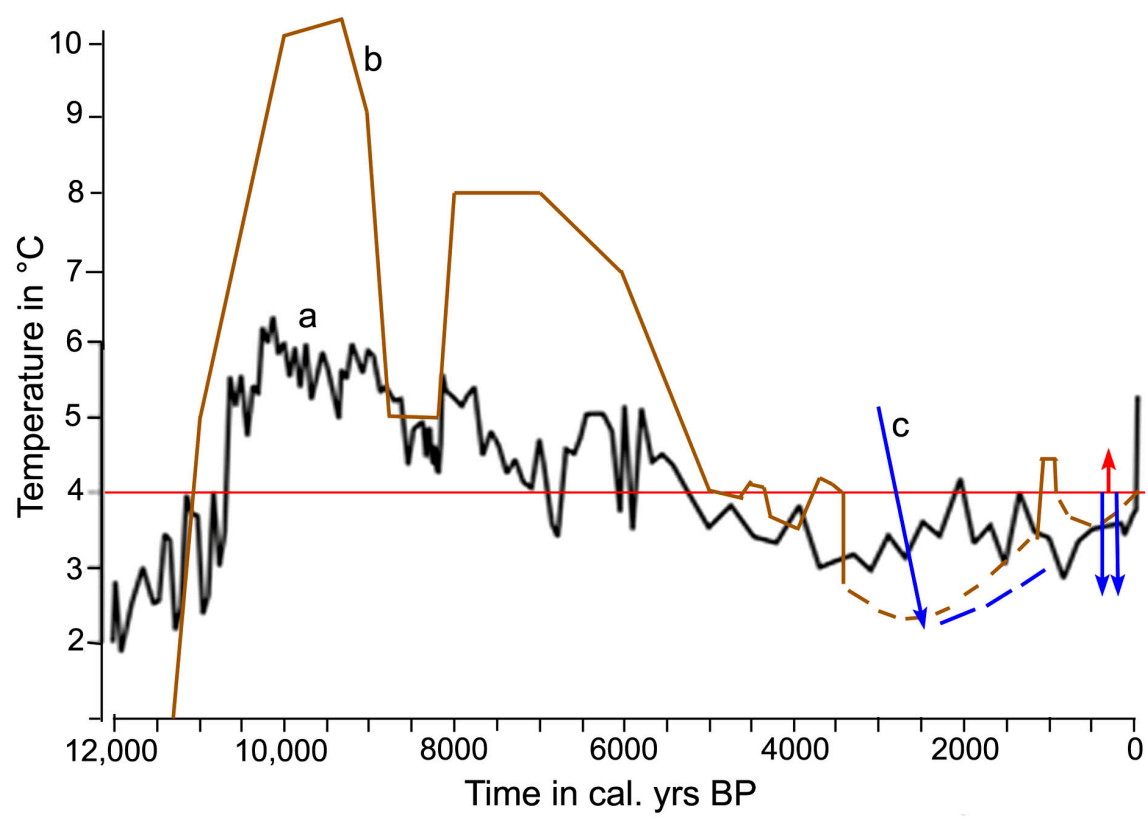

Figure 11. Temperature changes in the Svalbard region during the last 12,000 years; (a) according to Werner et al. [129], (b) according to Mangerud \& Svendsen [126], and (c) according to Humlum [130] and Humlum et al. [87].

in summer when daylight persists for 24 hours [108]. Since then, the Northern Hemisphere summers have gradually seen decreasing incoming solar radiation. The peak insolation is reflected in paleoecological data from the Arctic, where the Holocene thermal maximum, resulting in northward movement of the tree-line and shrub tundra replacing herbaceous tundra north of the tree line, occurred close to the Pleistocene-Holocene transition, broadly in the interval between 13 7.5 Ka BP depending on latitude [109].

The Holocene changes in glacier extension and temperature in the Svalbard region have been studied by several authors (e.g. [87] [110]-[128], all of which indicate an early Holocene with climatic conditions significantly warmer than today, and a late Holocene of cooling conditions as illustrated in Figure 11.

Figure 11 gives the general changes in temperature in the Svalbard region during the last 12,000 years. Curve (a) gives the changes in water temperature at a depth of $100 \mathrm{~m}$ in the Fram Strait according to Werner et al. [129]. Curve (b) gives air temperature change in Svalbard according to Mangerud and Svendsen [126]. Curve (c) gives the major changes in ice conditions with arrows indicating the increase to a maximum at about 2300 cal. yrs BP (cf. above; Humlum et al. [87]), the major sea ice expansions in the periods 1660 - 1720 and $1800-1818$ and retreat at around 1769 [130] (see Figure 12). The main trend is clear; a rapid rise in temperature in early Holocene followed by a temperature well above the present from 10,500 to 5500 cal. yrs BP (with a period of low temperature 8500 8200 cal. yrs. BP) and values below the present from about 3000 to $100 \mathrm{cal}$. yrs BP. Curves (a) and (b) agree well in general trend, but differ in details. The Late Holocene is best covered by the data of curve (c), too few data for a detailed analysis of the last 2500 years, however. 
In much of the Nordic Seas the mid Holocene period 6 - 4 Ka BP encompasses a transition to reduced Atlantic Water influence and lower sea surface temperatures. The late Holocene period from ca. $4 \mathrm{Ka}$ BP to the present is characterized by sea-surface cooling caused by decreased Atlantic Water influence in the surface waters of the Nordic Seas, including coastal Svalbard (e.g. [116]). Atlantic Water inflows to the Arctic Ocean may also have been affected by bathymetric changes elsewhere in the Arctic (i.e., Nares Strait, Bering Strait and other eastern Canadian Arctic Channels). Of these, the opening of Bering Strait about 10,000 cal. yrs BP might be the most important because it introduces relatively fresh Pacific waters into the Arctic Basin. This may have strengthened the meridional Atlantic Water circulation through the Fram Strait, at the expense of Barents Sea inflow [79]. Jennings et al. [81], working on the East Greenland Shelf, found evidence for late Holocene cooling from 4.7 Ka BP, associated with southward expansion of the Arctic sea ice and increased polar water influence. A general shift towards cooling and return to the present tundra environments at many Eurasian arctic and subarctic sites apparently started around 4.5 Ka BP [109] [131]. Additional evidence for Late Holocene glacier growth on Svalbard was presented by Snyder et al. [121].

In Svalbard permafrost near sea level was reforming shortly before $3 \mathrm{Ka} \mathrm{BP}$ [87]. Furrer [112] [113] found evidence in NW Spitsbergen for a late Holocene glacier advance, reaching maximum size around $2.3 \mathrm{Ka} \mathrm{BP}$ and again during the Little Ice Age. Röthe et al. [123] studied the Karlbreen glacier in northwestern Svalbard. They documented a small to absent glacier from 9500 to $4000 \mathrm{cal}$. yrs. $\mathrm{BP}$, a significant expansion at $3600 \mathrm{BP}$, a glaciation peak at $2400 \mathrm{BP}$, a significant peak 1300 - $1800 \mathrm{BP}$, a peak $700-100 \mathrm{BP}$ and LIA peaks in the period $100-500$ cal. yrs BP. Snyder et al. [121], working in western Spitsbergen, recovered laminated sediments in a core in the proglacial lake Linnévatnet (W Spitsbergen) to reconstruct the glacial history of a presently ice-free cirque. Terrestrial macrofossils from the core were radiocarbon dated to provide a limit on the onset of glaciation, and indicate that a nearby short glacial valley (a cirque) was not glaciated until in the Little Ice Age. The absence of glaciation during earlier Neoglacial periods suggests local climatic conditions "favouring glacier expansion were either of greater magnitude or of longer duration during the 'Little Ice Age' than at any other time during the Holocene". Humlum et al. [87] described in situ subglacial vegetation beneath the glacier Longyearbreen. Dating of the plants recovered demonstrated a glacier advance of about $2 \mathrm{~km}$ during the last 1100 years.

Professor Hubert Lamb stands out as one of the key persons in the understanding of climate change in historical times (e.g. [49] [132] [133] [134] [135]). Besides his excellent analyses on the changes in temperature, wind and ocean circulation, he also gave vivid examples on the cooling during the Little Ice Ages in the form of the sudden appearance of Eskimos in kayaks at the coast of Scotland and the drop of ocean surface temperature between Iceland and the Faroe Island of about $5^{\circ} \mathrm{C}$ [135]. 
In the late $16^{\text {th }}$ century, climate conditions were favourable and Dutch sailors attempted to find the northeast-passage to the Pacific. During one of the expeditions, Willem Barents in 1596 discovered Svalbard, which obviously then must have been accessible, indicating warmer climatic conditions (cf. peak at around 1600 in Figure 4). His discovery route is shown on a sea map from 1599. The discovery was challenged by the English, who claimed Svalbard was discovered by Hugh Willougby already in 1573. In our BIE series we have data back to 1579, almost 20 years before the discovery of Svalbard by Barents.

The whaling industry flourished in the $18^{\text {th }}$ century, and in the year 1769 there are firm evidence that the spring maximum ice edge was north of Svalbard, and even north of the 1966 position as indicated in Figure 12, and further discussed in Part 2 [136]. The $18^{\text {th }}$ century was, on the whole, a period of warmer climatic conditions in Northern Europe (cf. Figure 4).

Figure 12 by Humlum [130] provides an expressive paleoenvironmental map of the Northeast Atlantic region during the 1660 - 1720 period with ice positions compared with 1769, 1899 and 1966. The period of cool climatic conditions corresponds to the Maunder Minimum shown in Figure 4.

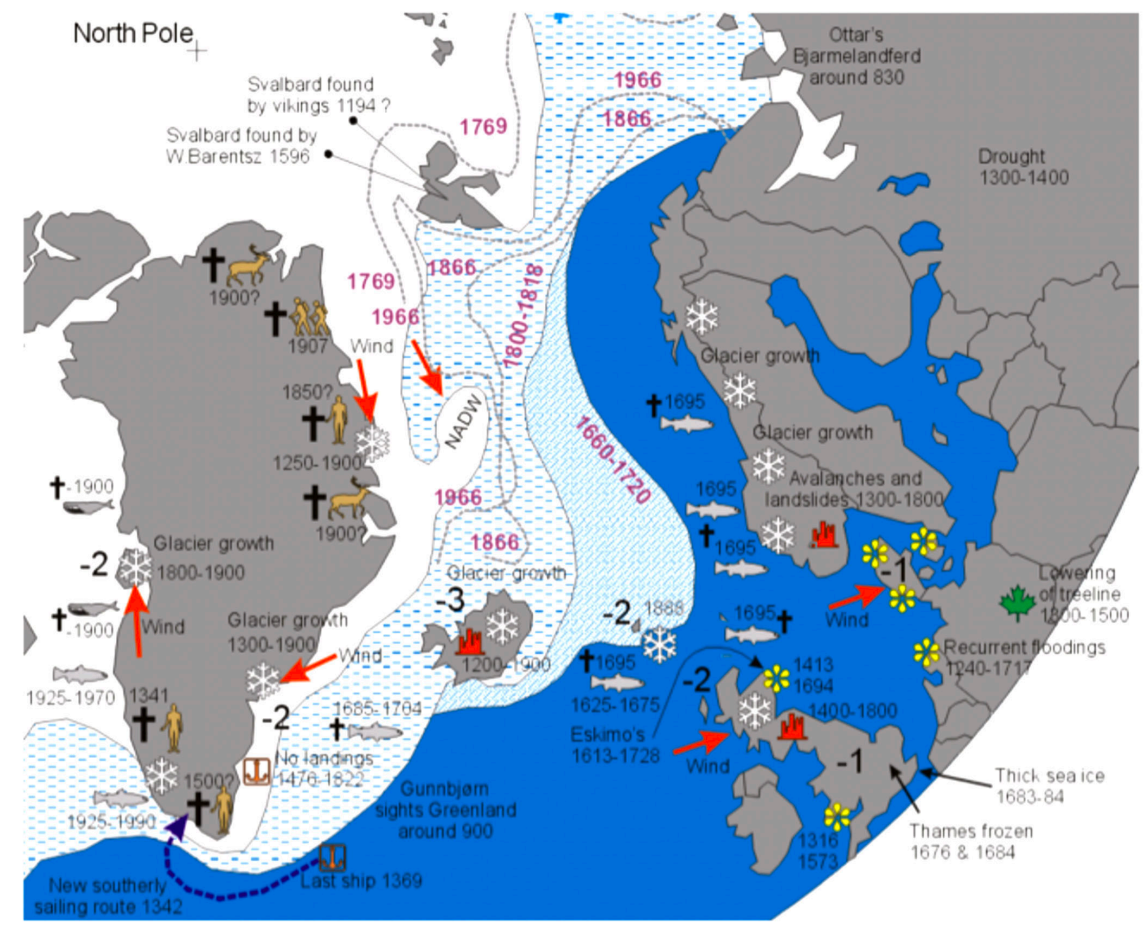

Figure 12. Palaeoenvironmental map of the Northeast Atlantic region (from [130]) during the Little Ice Age in the $17^{\text {th }}$ century with the spring maximum ice edge position in 1660-1720 and comparative positions in 1769, 1866 and 1966.

Figure 12 map is based on various written sources, including Lamb [49] [132] [133] [134] [135] [137]. Red arrows indicate prevailing wind directions. Symbols for animals and humans with black cross indicate reported periods of absence/extinctions. Symbols for ice crystals indicate periods with reported pe- 
riods of glacier growth. Yellow symbols (Europe) indicate periods with reported coastal flooding and/or strong coastal sand drifting.

The ice edge displacements documented in Figure 12 imply a manifestation of the beat between the cold East Greenland Current and the warm West Spitsbergen Current in pace with the Gulf Stream beat (Section 4); viz. an intensification of the East Greenland Current (and decrease of the West Svalbard Current) and a northward displacement of the ice edge during Grand Solar Maxima, and an intensification of the North Atlantic Current and the West Spitsbergen Current (and decrease of the East Greenland Current) and a southward displacement of the ice edge during Grand Solar Minima. Both the Maunder Minimum cold phase and the Dalton Minimum cold phase are well recorded in Figure 12 map. High-resolution sediment cores from the Fram Strait [129] provide too imprecise data to record this, however. This is also the case with a record of the last 2000 years [138].

\subsection{Observations Referring to the Last 150 Years}

Only a limited number of Arctic meteorological stations were in operation before 1910, and in few places have observations been carried out before the late $19^{\text {th }}$ century. In Fennoscandia, the oldest systematic climatic observations north of $65^{\circ} \mathrm{N}$ were in Tornio (Finland) during a period from 1737 to 1749 , while regular weather stations were initiated around 1850 . The first station in northern Russia was at Arkhangelsk in 1813. Early meteorological observations were initiated in Greenland in the period 1866-1895. Meteorological observations in the Arctic Ocean began at the voyage headed by F. Nansen on-board the "Fram" in 1894-1896 and were again taken up during the forced drift in the ice of other ships in the 1930s. The first real meteorological station in the High Arctic was Green Harbour (Svalbard) in 1911. A new phase of the Arctic data coverage started in the mid-1930s with North Pole Ice stations that continuously operated in the Arctic Ocean up to 1991. Economic reasons later caused a disappointing reduction in the number of existing Arctic meteorological stations during the 1990s, especially in northern Russia and Canada. The available meteorological records, however, clearly conveys the impression of high Arctic temperature variability; both on an annual basis and between individual regions in the Arctic.

Long Arctic surface air temperature records (Figure 13) illustrate conditions during the last cold interval of the Little Ice Age, which was terminated by a marked increase in mean annual air temperature around 1920. This rise was mainly derived from rising winter temperatures, while the temperature increased less in other seasons, especially summer. The termination of the Little Ice Age was followed by a warm period, recorded at many Arctic meteorological stations, continuing to around 1940-1950, where after a widespread cooling commenced. In some parts of the Arctic this cooling culminated around 1970-75 and was followed by a corresponding temperature recovery towards the end of the $20^{\text {th }}$ century. In some regions, such as Greenland and Iceland, cold conditions prevailed 
almost to the end of the $20^{\text {th }}$ century, while in other regions (e.g. Svalbard) temperatures have been rising without interruption since the cold period around 1970 [139].

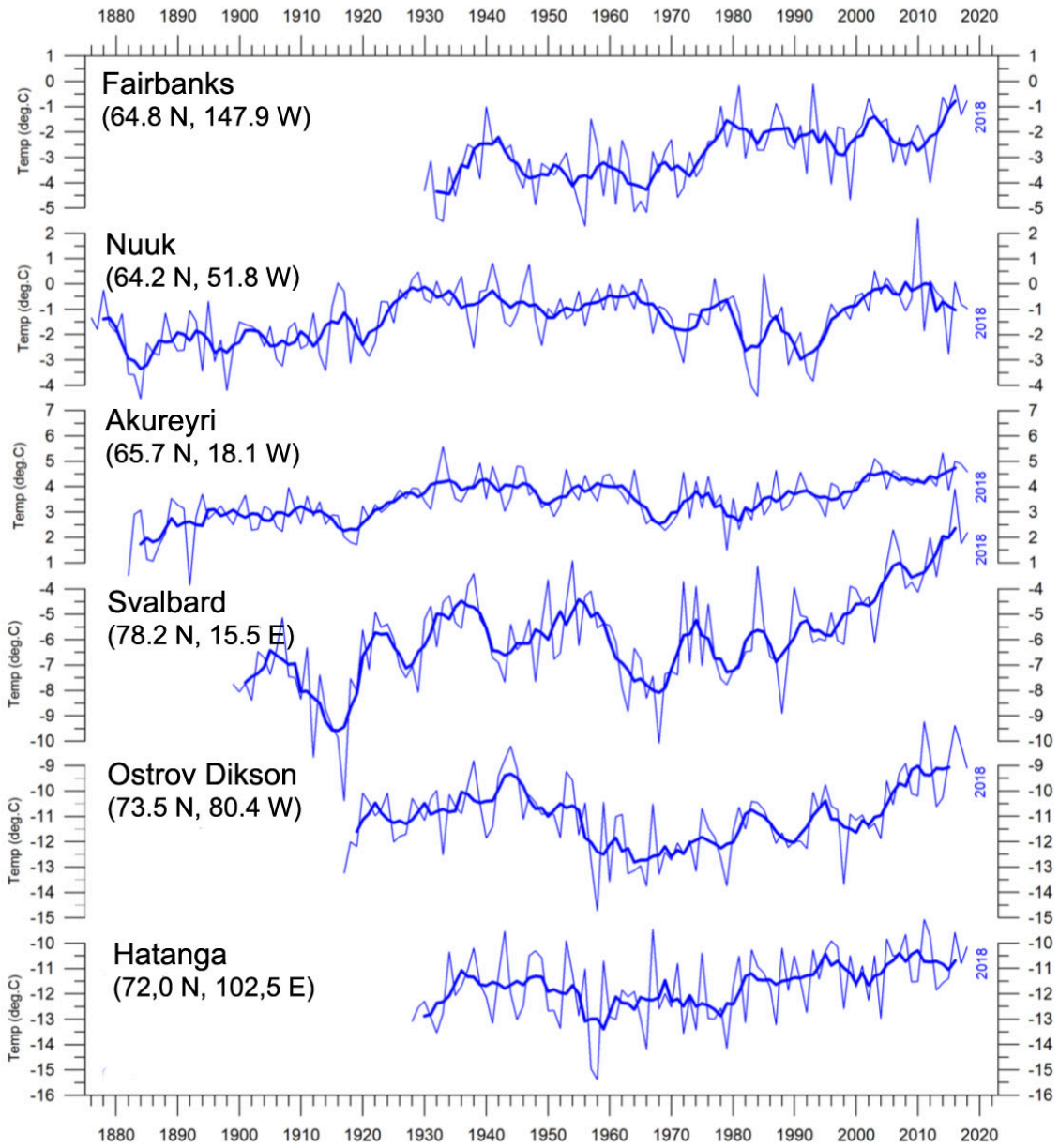

Figure 13. Long Arctic surface annual air temperature series (redrawn from [56]). The thin blue line represents the mean annual air temperature, and the thick blue line is the running 5-year average. Data source: NASA Goddard Institute for Space Studies (GISS) and http://www.rimfrost.no/.

The period 1915-1940 (Figure 13) represents a period of general warming in the Arctic especially influencing northern Alaska, northern Canada, Greenland and the northern parts of Russia and Siberia. The warming was by far most pronounced during the winter season (DJF) and least during the summer (JJA). The Svalbard-northern Russia region was exposed to relatively warm autumns (SON), suggesting increased cyclonic activity, leading to retreat of sea ice in the Kara Sea. This may be explained by the onset of a prolonged weakened state in the continentally based Siberian High in this period, as suggested by Meeker and Mayewski [82]. Hanssen-Bauer and Førland [140], however, suggested that the early $20^{\text {th }}$ century temperature increase in the Norwegian Arctic cannot be explained as a result of changes in advection alone. It may therefore be suggested 
that increasing cyclonic activity along the northern coasts of Russia and Siberia by wind stress may have contributed to opening of the sea ice cover, releasing heat from warm water below to the atmosphere, and thereby providing an additional source of heat. In order to illustrate the potential effect of this on air-temperatures, the average heat loss over the ice covered Arctic basin is about $6 \mathrm{~W} / \mathrm{m}^{2}$, while the heat loss to the atmosphere from the ice-free north eastern Greenland Sea averages is no less than $200 \mathrm{~W} / \mathrm{m}^{2}$ [141] [142].

Whatever the reasons for this warming may be, several very mild winters were recorded in W Greenland, most notably in 1929, where no land-fast sea ice formed at all and hunters were able to use kayaks throughout the whole winter [56]. At the same time new fish species appeared in the central W Greenland region, causing a significant change in Inuit hunting habits towards open sea fishing. The most important new species in the Disko Island region was the Greenland cod, locally known as the big-headed cod, which presumably is identical to the Icelandic cod [56]. Most likely, larvae of the Icelandic cod spread to SE Greenland waters in the early 1920s, driven by an enhanced Irminger Current, and for some decades were able to reproduce and survive in SW Greenland waters [143]. Whatever the precise background, this species represented a very important resource in Greenlandic economy for about 15 - 20 years, after which a decline set in, ending with a number of disastrous fishing seasons.

The changing ice conditions after 1920 also made the first navigation of the NE Passage without wintering possible in 1932 for the Russian trawler "Sibiryakow" [144]. Ten years later, in August 1942, the reduced sea ice extension prompted the German naval high command to order the heavy cruiser "Admiral Sheer" into the Kara Sea, to intercept suspected allied convoys from US and Canada with supplies to the Red Army, making use of the extraordinary open water conditions along the Russian and Siberian coasts at that time [145]. During this operation "Wunderland", famed "Sibiryakow" was regrettably sunk by "Admiral Sheer". The background for the German concern was the fact that a German raider, the "Komet", without great difficulties passed through the Northern Sea Route to the Pacific Ocean in summer 1940 [146] [147]. However, the Allies never attempted to make use of the NE Passage during the war.

Special interest has often been attached to the Svalbard region, as this part of the Arctic apparently displays a high climatic variability, as was recognized by both Ahlmann [148] and Lamb [132], and later by IPCC [149]. Significant climatic variations in the Svalbard region during the $20^{\text {th }}$ century are well documented by meteorological data since 1911 [139] [150] [151]. As an example, a marked warming around 1920 within 5 years changed the mean annual air temperature at sea level from about $-9.5^{\circ} \mathrm{C}$ to $-4^{\circ} \mathrm{C}$. This is one of the most pronounced increases in air temperature documented anywhere during the instrumental period. Later, from 1957 to 1968 the air temperature sharply dropped about $4^{\circ} \mathrm{C}$, with a subsequent more gradual increase towards the end of the $20^{\text {th }}$ century (Figure 13). The high climatic variability of the Svalbard region probably 
derives from three mechanisms. Firstly, the islands are located directly in the main transport pathway for air masses into the Arctic Basin [78] [152]. Secondly, Svalbard is located near the confluence of air masses and ocean currents with very different temperature characteristics. Finally, the variability is further enhanced by rapid variations in the sea-ice extent, coupled with both atmospheric and oceanic circulation [80] [153] [154] [155] [156].

Moving on to the period 1940-1965, in contrast to 1915-1940, this represents a period of cooling in many parts of the Arctic (Figure 13). Again, the temperature change was by far most pronounced during the winter and weaker during other seasons. Especially Alaska, NW Canada, Russia and parts of Siberia were affected by this development. The North Atlantic sector with Scandinavia at that time had relatively cold autumns, suggesting an increase of northerly winds. North Atlantic sea ice also increased in this period, and a greatly increased flow of the cold East Greenland Current brought polar water far south (cf. Figure 3(c)). In several years (1965 and especially 1968 and 1969) more Arctic sea ice came to the coasts of Iceland than seen for fifty years [137]. In April-May 1968 and 1969 Iceland was half surrounded by sea ice, which has not occurred since 1888. At the same time, the Greenland cod migrated to Iceland waters, and for a few years (1967-1971) offset the declining stocks there. The 1960s also saw the abandonment of attempts at grain growing in Iceland, which were resumed during the previous relatively warm period (1920-1950) after a lapse of some hundreds of years [137]. At the beginning of the $21^{\text {st }}$ century, grain (barley) was only grown at one farm near Skoga in southernmost Iceland, and only for making hay $(\mathrm{H}$. Björnsson, pers.com. 2003).

\subsection{The Last 50 Years}

The final ca. 30 years of the $20^{\text {th }}$ century has been a period of renewed warming in many parts of the Arctic, lending observational support to the common notion of 'Global Warming' [93] [149] [157] [158] [159] [160]. Again, this warming has been most pronounced in the winter season and less so in other seasons. The late $20^{\text {th }}$ century warming has affected especially western Canada, Russia and Siberia. This was accompanied by retreating sea ice in both the arctic North Atlantic sector, and in the Kara Sea, after reaching a maximum extension in the early 1970s (e.g. [161] [162]). A study by Winsor [163] concluded that the mean sea ice thickness in the Arctic Ocean remained constant from 1986 to 1997. Satellite mapping showed the late summer 2012 sea ice extension in the Arctic to be the smallest since initiation of satellite mapping in 1978. However, the sea ice expanded again in 2013 and 2014, and despite the season 2018-2019 showed the next smallest ice-covered area, there is no trend in September ice-cover 2007-2019.

An apparent paradox is that warming registered in the Atlantic water layer below the sea ice in the Arctic Ocean became noticeable in the early 1990s, whereas the major ice thinning occurred prior to 1990 [163], suggesting the dynamics of sea ice extension in the Arctic Ocean to be more complex than usually thought. 
Polyakov et al. [164] proposed that the Arctic Ocean has experienced an "atlantification" (i.e. increased role of Atlantic inflow) during the last decades. This seems contradicted by Klyashtorin et al. [165] who documented an increased Atlantic inflow through the Faroe-Shetland Strait from 1910 to 1970, a fall to low levels in 1980 and continued low levels at least up to 2000. Humlum [56] recorded a drop in the North Atlantic Current temperature from 2004 to 2019 with a peak-low in 2016. This can hardly be combined with an "atlantification" in the last two decades (nor is the general decreasing trend in warm water to the Arctic since 2011; Figure 10(A)).

According to Polyakov et al. [164] "the role of Atlantic water heat in sea-ice reduction is not negligible". Observations from the 1990s and 2000s documented two warm, pulse-like Atlantic water (AW) temperature anomalies on the order of $1^{\circ} \mathrm{C}$ (relative to the 1970s), entering the Arctic through Fram Strait and occupying large areas of the Arctic Ocean. The strength of the 2000s warming peaked in 2007-2008, with no analogy since the 1950s (cf. [166]). This AW warming has slowed slightly since 2008 . Ocean ventilation may have had pronounced effects on the ice edge position (a question to be returned to in Part-2 [136]).

Whilst the Arctic region, in general, records a warming during the last 25 years, the Eurasian region records a cooling [159]. According to Roy [93], this is the function of the weaker sunspot cycles in the last 40 years. The influence of the Sun on the Arctic winter climate goes via changes in Arctic Oscillation (AO). During winter solar minima, there is a warming over most of the Arctic (in December-February), especially over the Kara and Barents Seas, but a cooling over Siberia and Scandinavia [93].

\section{Life and Resources in the Arctic}

The ice cover in the European Arctic Seas affects the biologic productivity and the marine life in many ways and on all trophic levels. This includes the marine lightscape [167], the total primary production [168] [169] [170], the timing and quality of the primary and secondary production [171] [172] [173] [174], and the total production of commercial and non-commercial fish, seals and whale stocks [175] [176]. In this paper, we present data on the sea ice cover in the European Arctic from 1579 to 2018 (below). After a warm period that characterized the Viking time (see Figure 6) the winter temperature decreased rapidly from about 1030 and stayed relatively low in the Svalbard area until 1890 [177]. Despite that the period 1550 to 1890 in general was a period with very low winter temperature in Svalbard area, there has been periods with higher temperatures and a large variation in the summer (August) ice cover over the period 1580 to 2016 [177] [178]. The periods with little sea ice cover are associated with high biological production, fishing activity and hunting for whales and seals.

From Iceland, we have fish landings statistics covering the period 1600-1862 [179]. It shows "fluctuations of 50-60 years" with deep lows in the 1690s, 1750s and 1810s. 


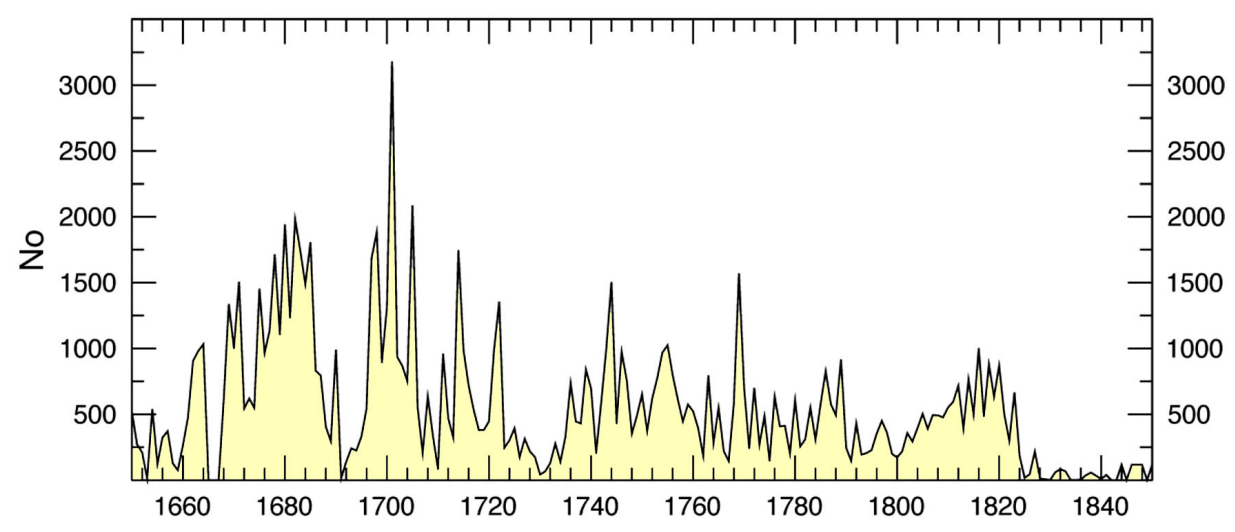

Figure 14. Reconstructed aggregate harvest of bowhead whales from the Greenland-Spitzbergen stock (from [183]).

\subsection{BIE in the Whaling Period}

Due to the pioneering work of Torgny Vinje [180] on assessing the location of the summer ice edge between Svalbard and Frans Josef Land $\left(20^{\circ} \mathrm{E}-45^{\circ} \mathrm{E}\right)$, based on log books of whalers, warships, early explorers, and scientist (e.g. [181]), and later airplanes and satellites, we have a record of the sea ice cover in this region, dating back to the 1580s. Falk-Petersen et al. [178] updated this time series to the present and related it to the primary and secondary production in the Whalers Bay north of Svalbard. They hypothesized that in periods with little ice the total bio-production in the European Arctic increased due to two main factors: a) the increase of the total area of open water available for primary production during spring and summer in the Barents Sea and Nordic Seas, and b) the winter upwelling of nutrient rich Atlantic water along the shelf break in the area north of Svalbard and Frans Josef Land fuels production hotspots in Whalers Bay as soon as the Sun returns. The high primary production attracts the lipid-rich Arctic grazing zooplanktons such as Calanus glacialis, Calanus finmarchicus and Calanus hyperboreus, the key species in the high latitude lipid-based ecosystems [169] [182].

The area north of Svalbard was called the Whalers Bay by the Dutch whalers, who carried out intense whaling here for more than 100 years. The peak of the whaling period, between 1660 and 1730, coincided with a period where the summer ice edge was north of $80^{\circ} \mathrm{N}$ for extended periods. Interesting, the short period with the expansion of the ice edge between 1730 to 1750 also showed a reduced catch of the bowhead whale as demonstrated in Figure 14 showing the reconstructed aggregate catch [183]. Comparing Figure 5, Figure 12 and Figure 14, we find that the maximum catch of more than 3000 bowheads happened in 1701 (i.e. at the end of the Maunder Minimum) when there was a type-c ocean circulation with cold water all the way south to Portugal (Figure 5). In historical time, it was the period with most spring ice in the North Atlantic and the sea temperature along the Norwegian coast was so low that the cod did not reproduce. 
The Whalers Bay in the Fram Strait is a high productive hotspot today, and we suggest that this also was the case in the period with the historical whaling from 1670 to 1790 , and that the high primary and secondary production sustaining the large stocks of whales and seals in this area [178] [183] [184] [185]. Bowheads are slow swimmers that feed by filtering zooplankton out of engulfed water masses with their 4.5 - $5 \mathrm{~m}$ long baleen plates. The main prey is the energy rich Calanus copepods such as Calanus glacialis and Calanus hyperboreus, but also other lipid-rich zooplankters [186] [187]. Weslawski et al. [184] estimated that bowhead whales consumed as much as 4 million tons of plankton per season from June to September in the Svalbard area at the peak of their abundance.

The documentation on the "French Naval Operations in the Spitsbergen during Louis XIVs Reign" further illustrates the productivity of this area in the Dutch whaling period. The commercial value of whaling activity was high and the commercial output of interest for several European nations [188]. In 1693, the French king sent a fleet of warships north of Svalbard to take the Dutch whaling fleet as prizes. On the 6th August 1693, the two French frigates Agil and Favori encountered and took a fleet of more than 40 ships, all flying the Dutch standard, under fire at the mouth of the Hinlopen strait (La Baye aux Ours-today Sorgbukta). The French frigates sized 13 ships and sunk a large part of the Dutch ships. The remaining Dutch whaling fleet escaped by sailing northeast in the ice-free area in the Hinlopen Strait. Despite the losses, the Dutch ship owners still were able to make a profit. The Dutch whaling stopped in some periods due to naval conflicts in Europe, for instance 1665-1667, 1691 and 1710 [183].

\subsection{BIE in the Post Whaling Period}

After the intense Dutch bowhead whaling period 1680 to 1790 , the sea ice expanded rapidly, and large parts of the Nordic Sea and the Barents Sea were covered by ice during spring and summer until 1910. Then the ice retreated rapidly until the 1940s, before the ice expanded again in the 1960s and 70s. In the long period with extensive ice cover after 1790, there was a short period with less ice around the 1850s and in the decade that followed. In 1873 the cod appeared on the banks of Spitzbergen, and a fishery was established the year after. The cod appeared in dense aggregations where the cod were feasting up on sea butterflies (Limacina helicina) [189] [190]. The fishery in this period was done by hand-line from small rowboats. The intense cod fishery off Svalbard (Spitsbergen) lasted from 1874 to 1882 [189]. Then there was a rapid retreat towards north by the ice edge between 1910 and 1940 (Figure 15) and already in 1931 H. U. Sverdrup [181] with the submarine Nautilus did marine research as far north as $82^{\circ} \mathrm{N}$ in the Fram Strait. In the 1930s there was an intense cod fishery off Svalbard with yearly landings of several million tons [191]. The Northeast Arctic cod stock in the Nordic Seas and the Barents Sea was strong during the mid-1950s, with a stock of about 4 - 5 million tons. However, during the cold 1960s and 1970s, with an expansion of the sea ice in the Barents Sea (see Figure 15), the stock was 
dramatically reduced to 1 million tons by 1964 [190] [192]. The cold period lasted to approximately 1985 in the Nordic Seas [169] [193], with persistent large ice cover in the European Arctic. This period falls together with a collapse both in the herring and in cod stocks in the Norwegian Sea and Barents Sea [190] [192]).

The expansion or contraction of distributional range of cod will often coincide with long-term temperature changes [194]. Northward expansion of the cod stock with increasing temperature and reduced ice cover has previously been documented during the warm periods of the late 1800 and during the 1920s and 1930s. During the warming event in the 1920s and 1930s and associated decreasing ice cover, the cod changed its distribution from southern Greenland up to Disko Island [195-197]. The cod was present as far north as the Disko Bay until the 1970s when they disappeared following a rapid decline in seawater temperature, with a slight recovery after the 1990s [197].

After 1990 there has been a rapid increase in temperature and decrease in ice cover in the European Arctic, followed by a large increase in the commercial fish stock in the Nordic Sea and the Barents Sea. In the Whalers Bay a mesopelagic layer of fish and zooplankton was recorded with an increased presence of mammals north of Svalbard [176] [185] [198] [199].

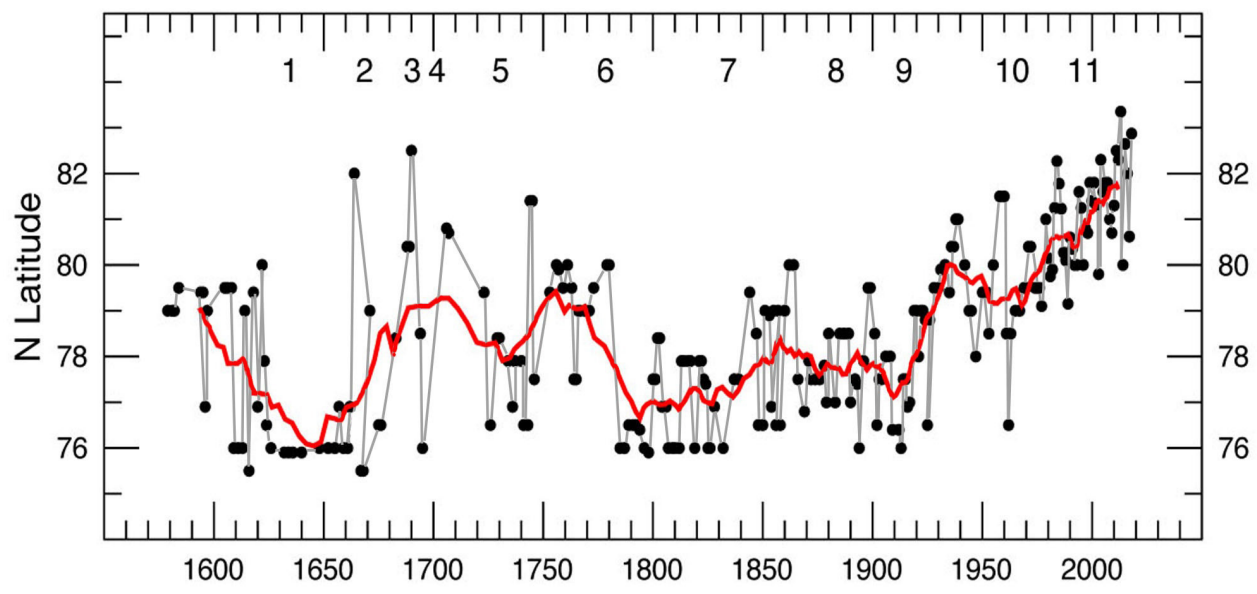

Figure 15. The estimated position of the BIE 1579-2018 (black dots) and an 11-point running mean (red curve). Some important events (marked 1-11): 1) 1611-51 approx. 250 whales/yr, 2) $1662-71$ increase to $2000 / y r, 3) 1689-1696$ reduced whaling, 4) 1701 max catch 3180 whales, 5) 1723-1735 reduced whaling, 6) 1750-1800 declining catch, 7) 1831 commercial whaling ends, 8) 1879-1882 rich cod fisheries in Svalbard waters, 9) Eastern Arctic bowhead assumed extinct, 10) 1955-1960 strong Barents Sea cod stock, 11) 1990-cod recovery, the bowhead is back.

Figure 15 shows the revised BIE position estimates for the period 1579-2018 (black dots) and an 11-point running mean. Some important biological events are marked with numbers (Figure 15, points 1 - 11). The red curve documents the presence of all the major solar maxima/minima known for the last 440 years (Figure 4); viz. little ice in the late $16^{\text {th }}$ century solar maximum, ice expanding from 1600 to 1650 corresponding to the first half of the Maunder Minimum. The 
retreat of BIE in the second half will be discussed in Part 2 [136]. Then we observe less ice during the $18^{\text {th }}$ century solar maximum, expanding ice from 1780 to 1800 referring to the onset of the Dalton Minimum, less ice in a short period around 1850, and rapid retreat of the ice edge 1910-1940. Finally, we observe more ice 1940-1970, and a retreat 1970-2010. Since 2010, except for the record low ice in 2012, the summer ice cover has not shown any significant decrease (http://nsidc.org/arcticseaicenews/). We may also notice the rapid expansion of the ice in the years 1614-1616, 1664-67, 1690-95, 1780-85, 1864-69, and 1960-62, which may be due to special weather events. Apart from the cycles, the dominating part of the curve is the gradual movement of the BIE northwards for more than 200 years (1800-2018).

Another interesting point is that the ice minima in 1760 and 1940 are 180 years apart. This may be related to the José cycle of 179 years [200], which is the fundamental orbital repetition period of the Jovian planets and is also synchronized with the sidereal orbital periods of Venus, Earth, Mars and Jupiter as well as the Schwabe (11.1 yrs), Hale (22.2 yrs) and Gleissberg (90 yrs) periods [201]. The mechanism and phase lock of these events will be discussed in more detail in Part 2 [136]. Since the 179 yrs period is a stable period, the José cycle may confirm an ice minimum in 1580 and predict a future ice minimum in 2120 .

\subsection{The Atlantic Ocean Oscillations}

There are a number of ocean oscillations systems like PDO (Pacific Decadal Oscillation), AMO (Atlantic Multidecadal Oscillation) and NAO (North Atlantic Oscillation), which sets the character of regional changes in oceanic environment. They are all included in the "stadium wave wheel" of Wyatt and Curry [202], indicating coupling and feedback interaction (Section 9.5 and Appendix 1). Easterbrook [44] [203] noted that glaciers on Mt. Baker in Washington State showed a regular pattern of advances and retreats, which matched the PDO variations. This has a bearing on the effects of changes in the North Atlantic (Gulf Stream, NAO, AMO) with respect to the changes in ice-edge position on the Barents Sea region.

The NAO index is defined as the normalized pressure difference between subtropical high and Icelandic low pressure. Its connection to the Arctic Ocean oscillation (AO) is well described by D'Aleo and Easterbrook ([204], Fig. 11.16) indicating alternations between stages of zonal jet stream and warm positive NAO conditions, and meridional jet streams and cold NAO conditions in the North Atlantic. The NAO-index was increasing from 1895 and had maxima between 1908-1926 and 1985-1997 and negative values 1955-75. It is about 70 years between its two maxima. The Earth's rotation (LOD) is negatively correlated with the integral function of NAO (INAO), and also with global sea surface temperature (SST) [65]. They [65] modelled SST based on LOD and INAO back to 1650 and found that the cold sea was dominating in the beginning of $18^{\text {th }}$ century, as shown in Figure 12, even if there were warm land temperature periods in Europe. 
Another anomaly was the period 1900-1930 with an increasing positive NAO and a cold SST [205]. Lansner and Pedersen [206] showed that in the warm period 1920-1950, it was only stations with little ocean influence, which showed warming, while the warming at the end of the century took place both at ocean affected and shielded stations. The result is a slight cooling for inland stations 1900-2010 measuring $-0.03^{\circ} \mathrm{C} /$ century, while ocean affected stations showed a warming $0.78^{\circ} \mathrm{C} /$ century. This is interpreted as a sign of a slow ocean warming since the cold LIA.

The AMO index (Figure 16) is defined as the pattern of sea surface temperature variability when the linear trend is removed [207]. It has a $65-70$ years' quasi-periodic variation [208]. The updated AMO series in Figure 16 has a period of 67 years. The BIE position variation is roughly in phase with the AMO index. During the period 1900-1925 the SST was cold, AMO negative, and NAO posive, which shows that AMO is dominating over NAO [205]. Both Alheit et al. [209] and Drinkwater et al. [194] discussed the AMO variations and recorded its effects on fish faunas and North Atlantic temperature and ice-edge variations. Mette et al. [156]] record a close correlation between AMO and changes in ocean temperature in northern Norway.

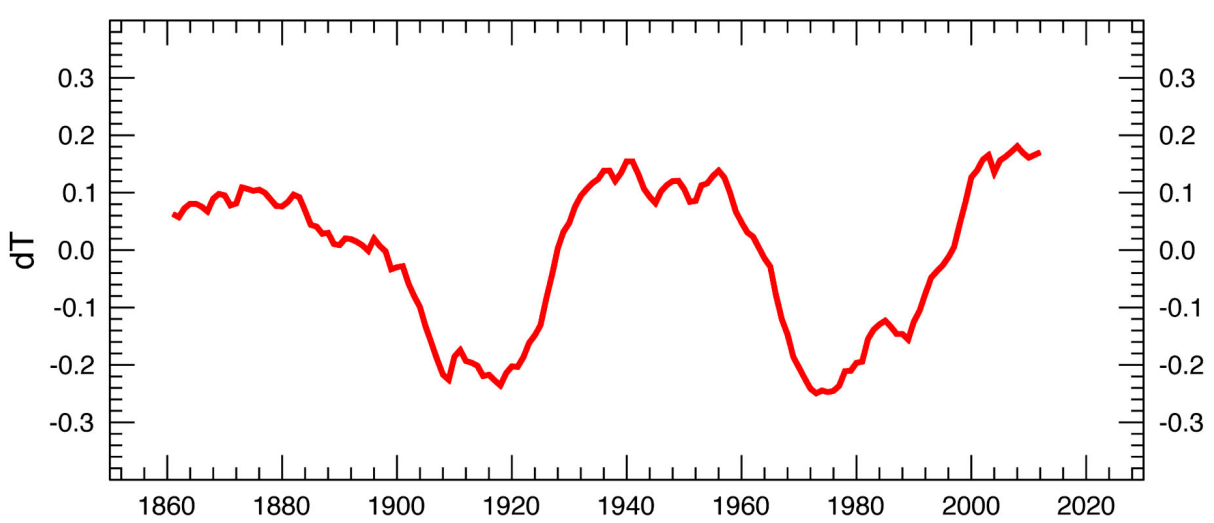

Figure 16. The AMO oscillation in temperature variation from 1856 to 2018 (11 yr running mean) ([207]; from http://www.esrl.noaa.gov/psd/data/timeseries/AMO/).

According to Klyashtorin and Lyubushin [210] and Klyashtorin et al. [165], the stocks of herring and cod in the Barents Sea fluctuate with a 60-year periodicity (the cods lagging by 8 - 10 years), which correlates with the changes in Arctic temperature, the ocean water temperature and the ice cover conditions in the Barents Sea, all exhibiting a 60 -year periodicity. Mörner [43] noted that the changes in ice cover reflect the "delivery of warm Atlantic water to the region" and that "the main source of heat delivered to the Arctic basin is warm water inflow from the North Atlantic Stream" as recorded by Nikolaev and Alexeev [211]. It agrees with the observed changes in Earth's rotation [36] and Gulf Stream beat [37]. This is illustrated in Figure 17.

This implies that the BIE position variations may be synchronized with the movements of planets in the solar system and follow the grand solar maxima/mi- 
nima alternations and the 60 -yrs cycle during the last 440 years. This suggests a primary planetary-solar forcing (further discussed below, and in Part 2 [136]).

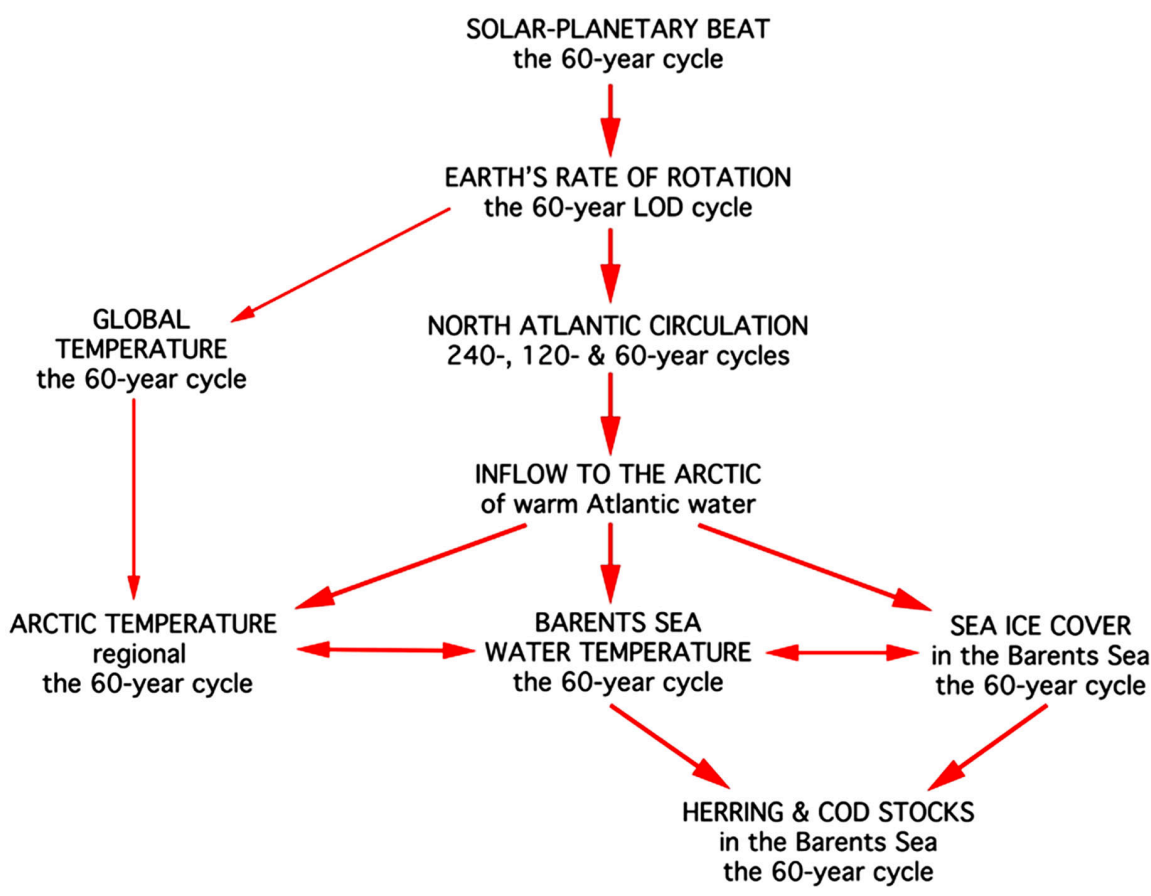

Figure 17. From planetary beat via a number of North Atlantic variables to the changes in fish faunas as observed by Klyashtorin et al. [165] (from Mörner [43]).

\section{Alternative External Driving Forces}

The Arctic sea ice grows in the winter, when it is cold and dark, reaching a maximum area in March/April. It then retreats to a summer minimum in late August or September. A recent re-calibration of Arctic sea ice extent datasets 1901-2015 (Fig. 10 in [212]) shows that the Arctic summer sea ice cover was growing until about 1920, then retreating slightly until 1960, when there suddenly became more ice, which retreated slowly until 1990, then faster. At the same time the annual average surface air temperatures in the Arctic changed in opposite directions, indicating that air temperature variations may be the first cause for ice cover variations.

For the Whalers Bay area, the winter sea ice loss has since 1979 been larger than for the Arctic in general. The winter ice loss trend has been close to $10 \%$ per decade. The reason may be $0.3^{\circ} \mathrm{C}$ warmer water in the Atlantic water pathway. Wind pattern may control the year-to-year changes, but influx of warmer water controls the decadal variations according to Onarheim et al. [213].

A new estimate of Northern Hemisphere and Arctic weather stations based air temperature variation, well supported by sea surface temperature trends, glacier length variations, and three rings proxy temperatures [214], suggest that surface temperatures in the Arctic increased during the period 1915-1940, decreased 1940-1970, and then increased from 1975, in good agreement with the proposed 
"Total Solar Irradiance" (TSI) according to Hoyt and Schatten [215] and updated by Scafetta and Willson [216], using the post 1980 ACCRIM satellite measurements for calibration (Figure 18).
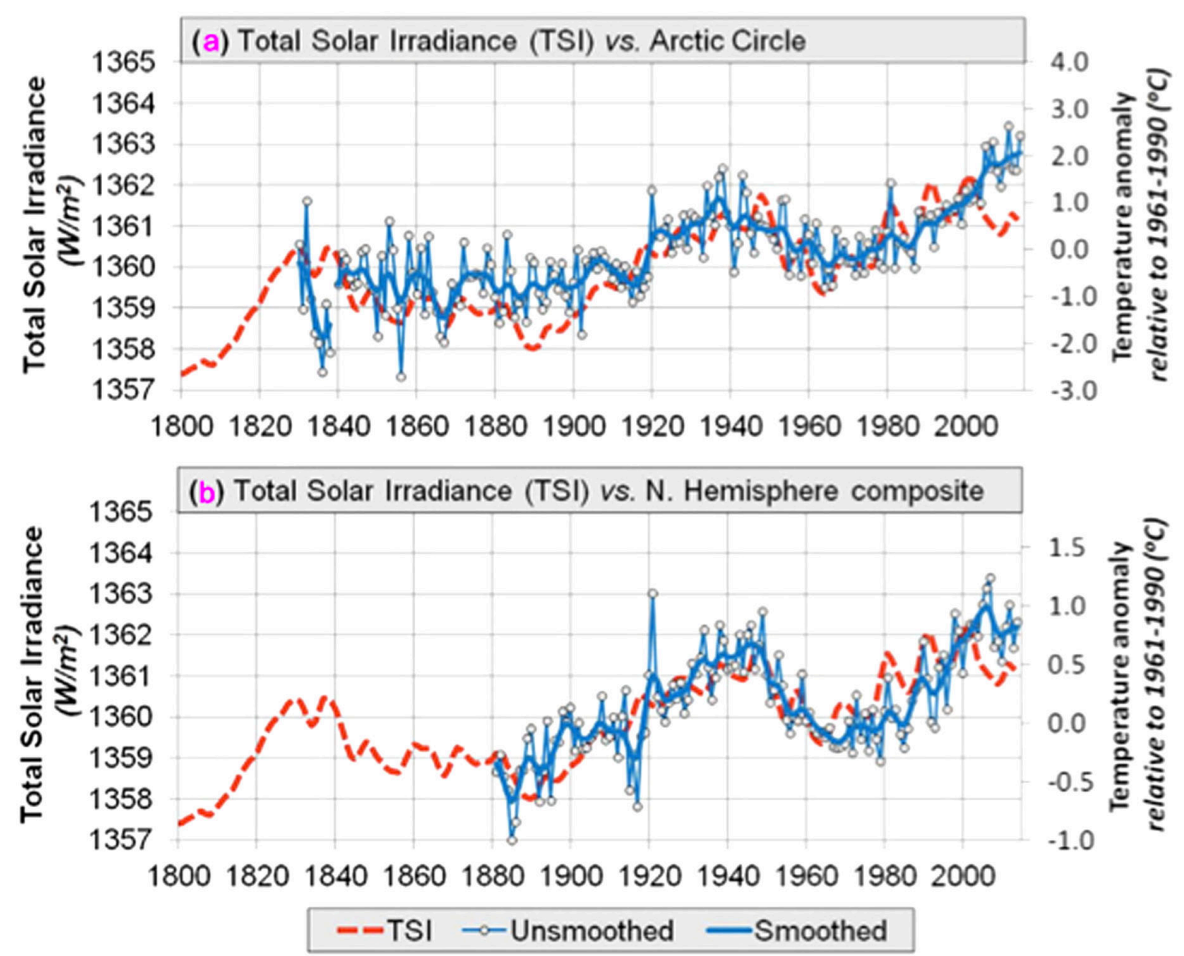

Figure 18. Comparison between Total Solar Irradiation (TSI) according to the Scafetta and Willson [216] calibration (red curve) and the composite temperature curve for Arctic stations (a) and a rural composite for the Northern Hemisphere (b) [214]. The Arctic temperature curve is based on data from 77 Global Historical Climatology Network stations above the Arctic Circle. The NH-composite is based on rural stations in the US, China, Ireland and Arctic. (Reproduced with permission from the authors W. Soon, R. Connolly \& M. Connolly).

In order to investigate the proposed solar-Arctic climate connection on multidecadal to centennial timescales, longer time series have to be analysed. It is important to keep track of systematic patterns as: seasonal and annual cycles, local and regional air pressure systems: topography, landscape, and storage and exchange of heat/energy through atmospheric and oceanic circulation and glaciation; and delayed actions [217]. An example of a coupled interaction is the 13 years' delay of the North Pacific Multidecadal Oscillation (NPMO) to the Atlantic Multidecadal Oscillation (AMO) [218].

In addition to direct solar irradiation, the Arctic warming is related to the atmospheric heat transport from the tropics to the Arctic, which is modulated by TSI variations with little or no delay [219]. This results in a warming of the mid and high latitudes while the tropics do not warm much. One example is the recent temperature "pause" (or "hiatus"), which is dominated by a slight cooling in the equatorial regions while the high latitudes are warming [220]. 
In the following we will discuss various driving mechanisms covering millennial, centennial, multi-decadal and shorter time scales.

\subsection{Millennial, Centennial and Multi-Decadal Solar and Planetary Cycles}

The interaction between Earth, the Sun and other planets in the solar system results in variations in the Earth's orbit on many time scales. Secular changes in eccentricity, axial tilt and precession result in long climate cycles, also called Milankovitch cycles [221] [222], which in generally are held to be the main reason for the Quaternary Ice Ages. The rapid changes of cooling and warming periods observed are in phase with ${ }^{10} \mathrm{Be}$ variations, however, which makes it more likely that solar activity is the main reason for the alternations between Ice Ages and Interglacial, between stadials and interstadials, and short-term changes in climate [48].

Analysis of solar activity in a 9400 -year long record of solar modulation potential $\varphi$ determined from cosmogenic radionuclides such as ${ }^{10} \mathrm{Be}$ and ${ }^{14} \mathrm{C}$ shows distinct periodicities of 88, 104, 150, 208 and 506 yrs [47]. They find excellent agreement between the long-term cycles and periods in planetary torque, suggesting a physical connection (see Figure 4). It should be noted, however, that they did not detect a 60 -yrs cycle in their analysis.

An analysis of the Zürich mean annual sunspot number $R z$ (1749-2009 AD), the group sunspot number $R h$, (1610-1995 AD), the Extended time series of Solar activity Indices (ESAI) (1090-2003 AD), and the simulated extended geomagnetic index aa (1619-2003) by Komitov et al. [223] show that in all series exists a strong cycle with duration $55-60$ years in the $18^{\text {th }}$ and $19^{\text {th }}$ centuries. It is less pronounced during the end of the $19^{\text {th }}$ and the beginning of the $20^{\text {th }}$ centuries. In all series except $R z$ there is also strong and stable quasi $100-120$ years and $\sim 200$ years cycles. In the $R z$ series a strong $\sim 95$ years period was present. Also quasi 40 - 45 and 30 years cycles are detected, but they are unstable during long time scales and have low amplitudes. An interesting difference is that the simulated aa-index shows a period 180 years while the $R h$ shows 202 years. Cliver et al. [224] found a strong correlation between decadal aa and global temperature values $(r=0.90)$ and conclude that $50 \%-100 \%$ of the temperature increase since Maunder Minimum is due to solar variability.

The solar dynamo theory [225] explains that in the beginning of a sunspot cycle, the dynamo process transforms the Sun's polar field into an internal toroidal field that increases during the maximum phase of the solar cycle, then affecting $R z$, when completing the sunspot cycle the toroidal field transforms into a poloidal affecting the aa-index. However, analysing wavelet power spectra Duhau and Chen [226] find that $R z$ and aa undergo cyclical oscillations whose amplitudes vanished in 1923. After that the ratio between $R z$ and aa increases from 5.3 to 12.4 and the phase difference decreases from 0.12 to 0.05 radians. They find that the secular $R z$ modulation steadily rise until the next Gleissberg 
cycle maximum in 1971. The temporal change in the coupling function between $R z$ and $a a$ is synchronous with a loss in the relationship between temperature and sunspot number in the period 1920-1955 [227]. For the secular changes in $R z 1844$ - 2000 Duhau and Chen [226] determined the following periods: 85.5, 121.1, and 171.2 years.

Finally, it may be significant to note that Blanter et al. [228] gave 4 possible explanations to the low values of the Solar Cycle 23: it may mark: 1) the beginning of a New Grand Solar Minimum, 2) the beginning of a new Gleissberg cycle, 3 ) the end of a great maximum episode, or 4) a random variation.

In order to forecast future variations, it is necessary to identify stationary oscillations. This was done for the first time for TSI variations and group sunspot series by Yndestad and Solheim [92], who searched for stationary components using the wavelet autocorrelation method. They found stationary components of the solar variability controlled by the 12 years Jupiter period and the 84 years Uranus period and its $3 / 2,5 / 3$ and $9 / 2$ harmonic components giving periods 125 , 210, and 373 years. The TSI record of Hoyt and Schatten [229] showed only the stable periods of Jupiter, Uranus and Neptune.

According to Kuznetsova [230], the changes of the terrestrial climate during the last millennium are driven by the interaction of Jupiter, Saturn, Venus, the Sun and the Moon.

Le Mouël et al. [231], analysed the $R i$ series by singular spectrum analysis (SSA) and found 4 components: a multi-secular trend with a slight acceleration around 1900, two Hale periods of 11.0 and 10.0 years, the fist increasing in amplitude, the second with secular amplitude variation with maximum around 1740 and 2010, and a clean Gleissberg period component which varied from 85 to 94 years with a decreasing amplitude-signalling a longer period beat. The multi-secular trend confirms the modern grand solar maximum from 1920 [3] [232].

Analysis of the last 4000 years of the reconstructed central Greenland surface temperature, derived from the bi-decadal $d^{18} \mathrm{O}$ record from the Greenland Ice Sheet Project II (GISP2) [233] [234] revealed periods $\approx 3500, \approx 1130, \approx 790, \approx 580$ and $\approx 370$ years [235]. A 3-period model based on non-linear optimization of the longest periods resulted in a good fit that clearly shows the timing of historical warm periods ([236], their Fig. 8).

A global temperature harmonic analysis [236] based on paleotemperature reconstructions and instrumental records for the period AD 1 to 2015 gave three significant periods: $\approx 1000, \approx 460$ and $\approx 190$ years in addition to a less significant period $\approx 60$ years. A 190 -year period was also found modulating the length of the sunspot cycles ([237] [238]).

Harmonic analysis of the HadCRUT4 global temperature (1850-2012) [239] showed that a linear trend of $0.5^{\circ} \mathrm{C}$ per century and periods 9.1, 21.6 and 66 years. A 9.3 years period is a harmonic of the 18.6 years lunar tide period. This period is also identified as a standing wave in the Atlantic Ocean by Mazimov 
and Smirnov [240] [241]. The 21.6 years period is close to the Sun's magnetic period, the Hale period of 22 years.

During solar cycles with negative polarity of the Sun's northern polar field, the Galactic Cosmic Ray (GCR) variation has a peaked form. In the other phase it has a plateau. This is an effect of the differences in cosmic ray drift in the positive and negative phases of the magnetic cycle. Integrated GCR counts are higher in plateau cycles compared with peaked cycles [242]. This may be the reason for the amplification of the 22 years component in the global temperature curve. The difference between 11 and 22 years climate response, is also seen in the latitudinal difference in the rhythm of growth in pine trees, (as shown in [239]; Fig. 6 ), where the 20 years period dominates north of 65 degrees latitude, while the 10 years period dominates at lower latitudes. This may be a result of differences in atmospheric circulation or effects of cosmic rays of lower energies reaching deeper at higher latitudes. For Svalbard at $78^{\circ} \mathrm{N}$, an analysis of temperature series by Humlum et al. [88] shows that periods 17 and 26 years are much stronger than those at $10-12$ years.

Kasatkina et al. [243] showed that dendrochronological data from the Kola Peninsula and Finnish Lapland recorded the effect of low-latitude volcanic activity with "significant decrease in polar tree-ring growth over 7 years after eruption", and "the main cycles of solar activity (11, $20-25$ and $~ 100$ years)".

The $66 \mathrm{yr}$ period can be explained as a harmonic solar $(3 * 22=66 \mathrm{yr})$ or lunar $(3.5 \times 18.6=65.1 \mathrm{yr})$ period. A maximum entropy power spectra analysis by Scafetta [244] showed that 9 different global and regional temperature series contained the same 10 spectral cycles from the Sun and the Planets, in addition to a 9.1 years period from the Moon.

Scafetta [245] demonstrated multi-frequency spectral coherence between planetary and global surface temperature oscillations by advanced techniques and statistical significance tests, with large coherence peaks of 20 and 60 years quasi-periods. The latter has maxima around 1880, 1940 and 2000.

Periods mentioned above may well be present in global time series, but the sensitivity of the local (high latitude) climate is different from low latitude sensitivity, and the combination of thermal-salinity-cryospheric interactions, also involves lunar and orbital forcing, acting different at seasons. A framework for the solar-lunar-orbital interaction for high latitudes is presented by Cionco et al. [246] and demonstrated in Figure 19. The latitudinal temperature gradient (LTG) drives the (wind driven) ocean circulation between the tropics and the polar regions. Analyses of recent changes in LTG suggest that the Earth's climate system is unusually sensitive to changes in LTG [247]. LTG varies according to seasons. In the $\mathrm{NH}$ summer the variation in obliquity is dominating with $41 \mathrm{Ka}$ orbital and 18.6-yr lunar cycle. In NH winter the TSI is dominating with 11yr cycle [90] [246]. The LTG is clearly modulated by the TSI variations [219] and represent a channel both for solar and lunar forcing of Arctic climate. 


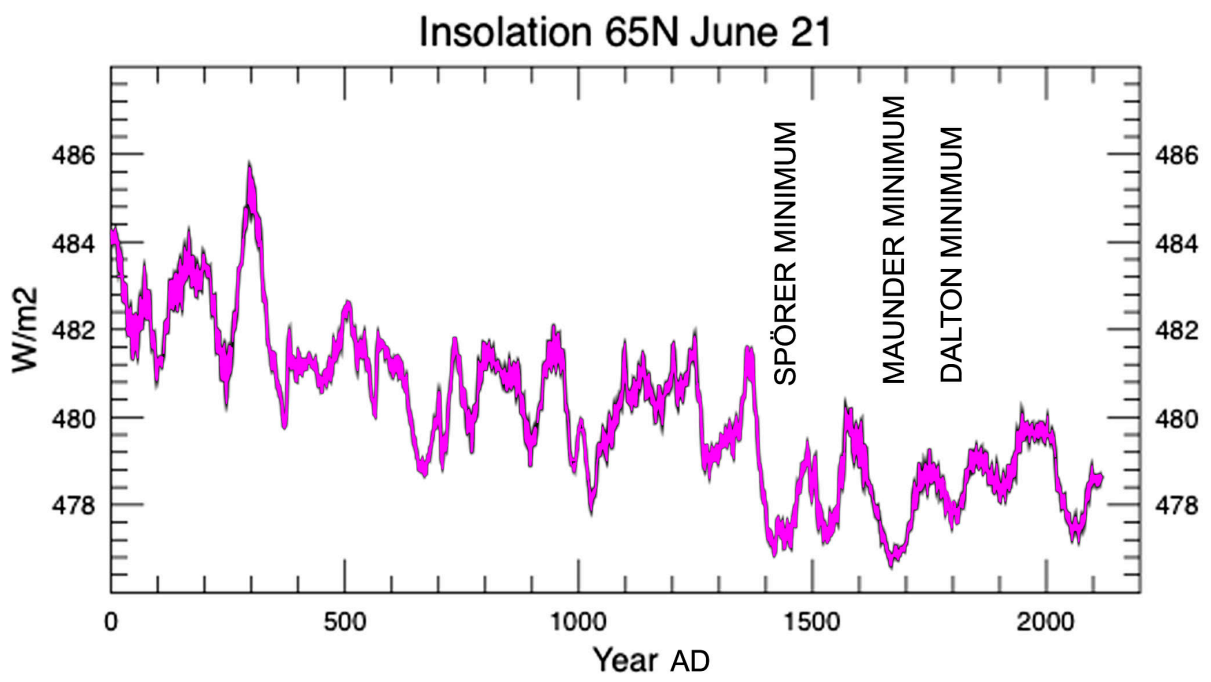

Figure 19. Mean daily irradiance at $65^{\circ} \mathrm{N}$ for the summer solstice based on a variable TSI and variation in the Earth's orbit due to interaction from the Moon and other planets (modified from [246]). The Spörer, Maunder and Dalton Minima are easily observed, like the 1920-2000 high and a coming minimum 2020-2085.

\subsection{Lunar Cycles}

Treloar [95] identified that lunar-solar forces produce multiple tidal ocean effects with periods of $86.795,46.22,13.53,18.02$ and 20.295 years. Lunar Nodal oscillation components of $\sim 56$ and $\sim 74$ years are observed in the North Sea, Kattegatt and Baltic tide gauge data [248] [249].

An analysis of time-series for the North polar position, extent of Arctic ice, sea level, sea temperature, air temperature, and the NAO winter index shows that a harmonic spectrum from the 18.6-year lunar nodal cycle is present in all time-series [86] [96]. The cycles in the harmonic spectrum have stationary periods but not stationary amplitudes and phases. A sub-harmonic cycle of 74 years may introduce a phase reversal of the 18.6-year cycle.

Correlations are also found between the lunar nodal tide effect and temperature and salinity in hydrographic time series for the Faroe-Shetland channel and the Kola Section, suggesting that the temperature and salinity variations are forced by harmonics of the nodal tide [96] [250]. Dominating periods were the 18.6 yr lunar nodal period and its 9.3 year harmonics.

\subsection{Solar and Lunar Cycles and Earth's Orbit}

Davis and Brewer [90] stated: "empirical evidence suggests that extraterrestrial forcing influences the Earth's climate" (a notion that we certainly agree with), and they presented data in the effort of "unifying orbital, solar and lunar forcing".

Figure 19 shows the summer insolation at $65^{\circ} \mathrm{N}$ during the last 2000 years [246]. It gives the combined effect of variable TSI and orbital variations due to lunar and planetary cycles, including solar variability. The rapid decline 1350-1400 
coincides with the start of the Little Ice Age (LIA), which had its maximum cold period 1687-1703, according to the longest instrumental temperature record from Central England [251]. Recovery from this cold period was first visible in the Arctic from about 1920 as demonstrated in Figure 12 and Figure 15. The summer insolation at $65^{\circ} \mathrm{N}$ increased in three steps after 1700 with the recent $1920-2000$ maximum being the highest. After 2005 the June 21 TSI at $65^{\circ} \mathrm{N}$ is decreasing with a minimum in 2045 and a recovery at a lower level about 2085.

It is interesting to notice that a major reorganisation in atmospheric circulation took place about 1420. During the preceding Medieval Warm Period, winter storminess across the North Atlantic was at a minimum. This is confirmed in $\mathrm{Na}^{+}$deposits in the GISP2 borehole in Greenland [252]. After 1420 until about 1925 cells of winter Icelandic low pressure have been strongly anchored within northern hemisphere circulation, which has resulted in increased frequency and severity of North Atlantic winter storms. This corresponds to a period of reduced June 21 solar Insolation at $65^{\circ} \mathrm{N}$ (Figure 19). A reduction in winter storminess is documented for Grimsey and Stykkisholmur weather stations in Iceland after 1920 [253].

\subsection{Changes in the Earth's Shielding Capacity}

The Earth's magnetic field is modulated by the solar wind, which varies in phase with the solar activity or sunspot cycles, with an average period of 11.06 years. At maximum solar activity the shielding capacity of the Earth's magnetic field against cosmic rays from exploding stars is maximum, and this reduces the number of cosmic rays that hit the Earth. Since cosmic rays may be related to formation of clouds [254], this has a climate effect. We can therefore expect less clouds and higher temperatures at solar maxima. The variations in the solar wind amplify the TSI-effect on the Earth's climate, and longer periods with reduced solar wind intensity are in general cold periods on Earth (cf. Figure 4).

A linear relation between sunspot numbers and the rotation of the Earth, or the length of the day (LOD), shows that increased solar activity or strong solar wind decelerates the Earth's rotation (Fig. 2 in [37]). This affects the oceanic and atmospheric circulation systems (cf. Figure 9), both of which have a significant effect of terrestrial weather and climate. The relations among solar activity, irradiance, solar wind, variations in the Earth's atmospheric shielding and variation in LOD are visualized in Figure 20.

The changes in Earth's shielding capacity are recorded in the changes in atmospheric ${ }^{14} \mathrm{C}$ production. Figure 4 gives the changes from AD 950 to 1950. The production is modulated by a $210-y r$ periodic fluctuation, which corresponds to the 208-yr period observed by Abreu et al. [47] during the last 9400 years. The cycle had its maximum in 1910 and a minimum in 2005. This signals the end of the warming period.

The shielding capacity is a function of the solar wind, which brings magnetic plasma, which strengthens the Earth's magnetic field. Weaker solar wind means 
less shielding. 30 years of output from a data-constrained magneto-hydrodynamic model of the solar corona has made it possible to model solar wind variations over the last four centuries [45] as shown in Figure 21 for the equatorial component that hits the Earth. The global solar wind variations show main evolution in four zones: 1) the Maunder Minimum of lower solar wind speed values, 2) the $18^{\text {th }}$ century of generally higher values, 3) the Dalton Minimum of lower values, and 4) the last 180 years of surprisingly similar values.

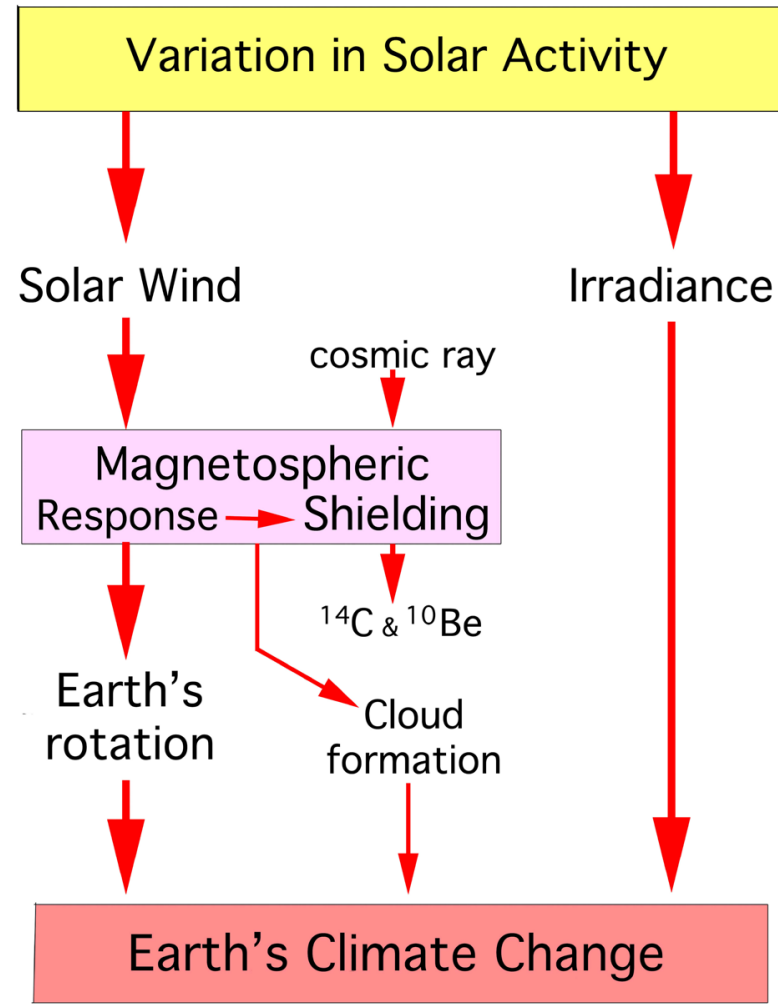

Figure 20. Variations in solar activity affect the Earth's rotation, cloud formation and solar irradiance). The isotopes ${ }^{14} \mathrm{C}$ and ${ }^{10} \mathrm{Be}$ may be used as indicators for past solar activity [37].

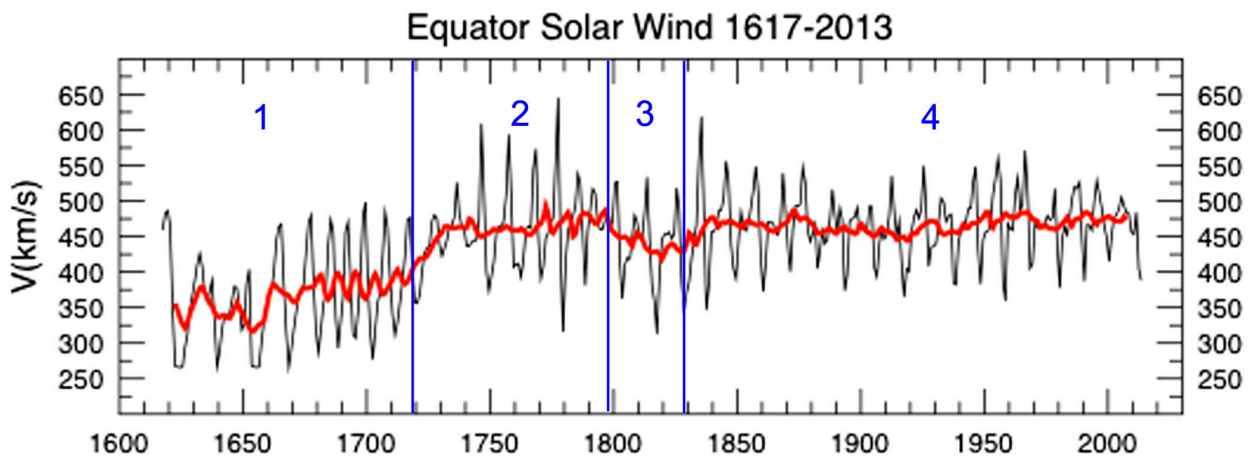

Figure 21. Estimated helio-equatorial mean solar wind speed 1617-2013 at the distance of one astronomical unit (AU) from the Sun, the red curve is an 11-yr running mean. Four zones are identified: 1) the Maunder Minimum, 2) the $18^{\text {th }}$ century high, 3) the Dalton Minimum, and 4) the last 180 years with a fairly constant level (modified from [45]). 
Figure 22 shows solar wind measured by spacecraft in geocentric orbits, made available through the omniweb.gsfc.nasa.gov website, and observations at the Oulu neutron count detector. Neutron counts are a good measure of cosmic galactic rays (GCR) particles and are clearly anti-correlated with the solar wind. The figure shows that the solar wind has decreased more than $30 \%$ from the peak in 2004. Since 1990 the neutron counts (GCR) has increased and the solar wind speed decreased indicating that Earth's shielding capacity has decreased considerably since 1990 (Figure 22).

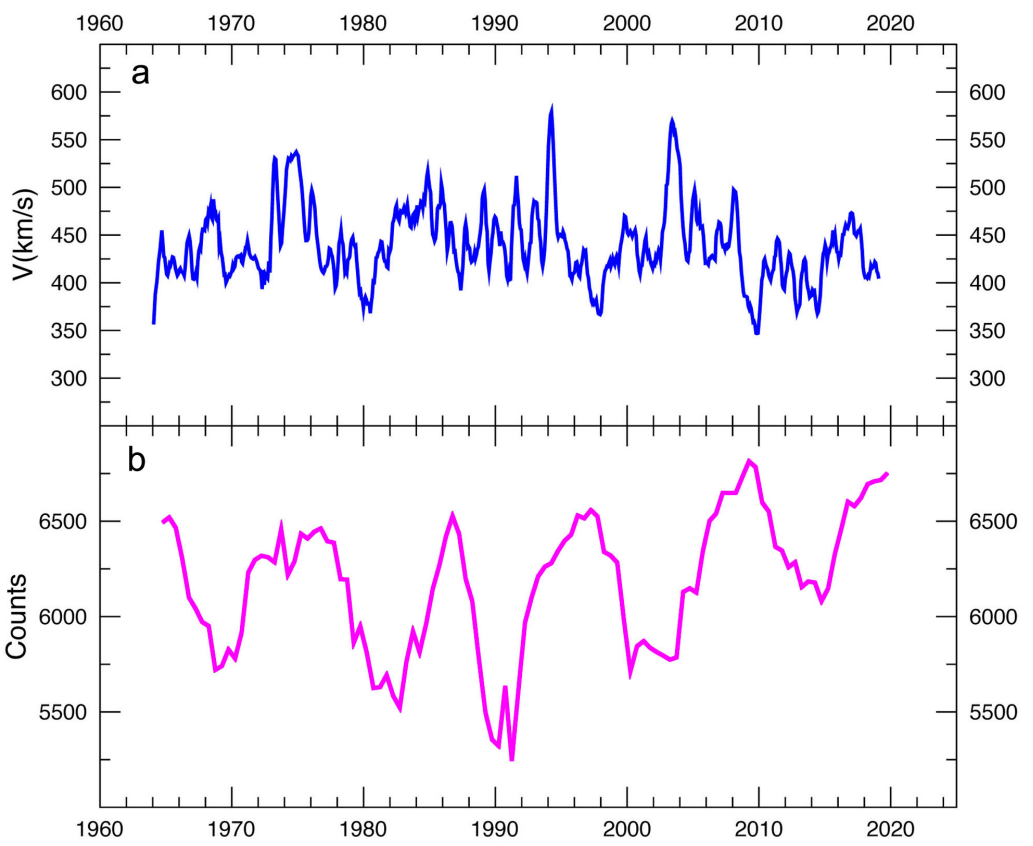

Figure 22. (a): Solar wind measured at the Earth's orbit (6 solar rotations running mean; https://spdf.gsfc.nasa.gov/pub/data/omni/low_res_omni/extended/omni_27_av.dat), (b): Oulu neutron counts (6 months average; http://cosmicrays.oulu.fi). Both graphs show a change in mean trend at about 1992 indicating the onset of decreased shielding capacity.

Bucha [75] demonstrated that increased corpuscular radiation (as recorded by the neutron counts) implied enhanced penetration of electrons into the middle atmosphere and stratosphere, resulting in increased temperature and atmospheric pressure in the stratosphere and troposphere in the auroral oval. This leads to a change from a meridional to a zonal type of atmospheric circulation over the Arctic. Visa versa, low corpuscular magnetic activity leads to low temperatures in the stratosphere. Further effects on the Solar Wind interaction with the terrestrial system are given in Figure 9 (cf. [43] [63] [64]. Kuznetsova [230] identified a 198 yrs magnetic field cycle and a 54 yrs solar wind cycle in terrestrial temperature data.

A closer study of the geomagnetic activity over the past century of the solar wind flow speed $V s w$, the interplanetary magnetic field strength $B$, and the open solar flux $F$ s, indicate that the grand maximum started in 1920, peaked around 1955 and 1986 and then declined. Extrapolating the linear decline trends indi- 
cate that the grand maximum of the three parameters will end in 2013, 2014 and 2027, respectively [232].

\section{Internal Coupling and Feedback Processes}

We have previously discussed possible external driving forces for the main Gulf Stream beat as well as for the BIE variations. In this section, we discuss internal coupling and feedback processes because they provide insights into the dynamics on the regional dimension.

\subsection{The ENSO Events}

The equatorial current lags behind the rotation of the solid Earth, which lead to an accumulation of warm water-masses outside East Asia rising local sea level by about $30 \mathrm{~cm}$. At El Niño events, $0.4 \mathrm{~ms}$ of the rate of rotation (LOD) is transferred from the solid Earth to the hydrosphere, which is manifested in an eastward migration of the water-masses from East Asia towards the west coasts of the two American continents. When the water hits the west American coasts, sea level rises by about $30 \mathrm{~cm}$, and $0.4 \mathrm{~ms}$ in rotation (LOD) is transferred back to the solid Earth. This provides a significant documentation of the interaction and feedback coupling between the redistribution of mass (water) and changes in rotation with the interchange of angular momentum between the solid Earth and the hydrosphere [36] [43].

\subsection{The Gulf Stream Pulsation and Earth's Rate of Rotation}

Mörner [255] noted that the Gulf Stream exhibited a pulsation of 16 cycles within the Holocene, recorded in high-resolution deep-sea cores, sea level changes in the Kattegatt-North Sea region, and temperature changes in Northwest Europe. He interpreted this in terms of a feedback coupling between water masses redistributed from low latitudes to middle-to-high latitudes, and changes in Earth's rotation in order to compensate for this. We now know, that the primary driving force is to be found in external planetary interaction with the Sun and the Earth (Figure 9; [37] [43] [63]).

The Gulf Stream beat system proposed by Mörner [37] has a close relation to the alternations between NAO+ and NAO- stages recorded by Wanner et al. [256]. Their main illustration (Fig. 9 in [256]) has been endorsed and reprinted by Pinto and Raible [257] and Boström [258]. Whilst the Gulf Stream beat theory has a driving energy input from external forces (Figure 7 and Figure 9), the NAO theory of Wanner et al. [256] is based on internal interaction and feedback process. It seems significant that Wilson (2011) concluded that he had presented facts, indicating, "that the phases of two of the Earth's major climate systems, the North Atlantic Oscillation (NAO) and the Pacific Decadal Oscillation (PDO), are related to changes in the Earth's rotation rate". As shown by Mörner [36] [37] the changes in rotation originate from planetary-solar beat as illustrated in Figure 9, i.e. from external sources (Figure 7). 


\subsection{The Ocean Oscillation Interaction}

In his account on "the Lunar nodal cycle influence on the Barents Sea", Yndestad [259] [260] presented both an internal and an external view of the climate feedback loops of the Arctic; i.e. the coupling and interaction between temperature, water, ice extent and light reflection in the Arctic region of the Atlantic sector.

He noted that his first lunar view model was good to illustrate the fundamental dynamics operating with respect to feedback loops in an autonomous dynamic system. This model represents the internal interaction and feedback processes. He noted that this model was not enough, but called for external oscillating forces.

In his external forced oscillators model, he included solar/orbital influx (from the Milankovitch variables), Moon orbital forces (tides and rotation) and $\mathrm{CO} 2$ effects.

Today, we know that the Sun varies in quite another way, and that the planetary beat effects the Sun, the Earth and the Earth-Moon system (Figure 9).

Yndestad's thesis [259] [260] is deeply relevant, because it at the same time as it shows the fundamental interaction and coupling between different internal parameters, it also calls for external forcing functions (today in improved understanding, however).

\subsection{The Rotating Wine Glass Mechanism}

The polar position oscillates with periods 6,18 , and 74 yrs cycles, all related to the 18.6 lunar nodal cycle.

Yndestad [259] explains that in the cold Arctic Ocean, water accumulates in circulating layers, the Arctic Surface Water, the Atlantic Water, the Deep Water, and the Bottom Water, all of which have different densities and circulation patterns. The Atlantic Water residence time is about 25 years, while the Deep Water residence time is about 75 years, which is the same period as the polar motion. His model is that the gravity force from the 18.6 years lunar nodal cycle, influences the polar position and most likely the circulating water in the Arctic Ocean, the Arctic ice extent, and Arctic atmospheric condition. A continuous source of energy from the stationary polar position cycle is transformed into a spectrum of oscillating water circulation periods, where some harmonic cycles are preserved by resonance. This is the base for "The wine glass theory", that the rotating Arctic Ocean behaves like liquid in a rotating wine glass, where the Deep Water oscillation has a resonance of about 74.5 years. The denser Bottom Water has a resonance of $4 \times 74.5=290$ years, while the less dense Atlantic water has a resonance $74.5 / 3=25$ years.

Yndestad [259] presents the detection of lunar nodal oscillation or harmonics in all Arctic climate time series analysed (Barents Sea ice extent, Kola section ocean temperatures, Hammerfest tidal variations, Greenland Sea ice extent, Røst winter temperature, and $\mathrm{NAO}$ winter index). $\mathrm{He}$ concludes that these stationary cycles may enable us to predict the future Arctic climate. 


\subsection{The "Stadium-Wave" Mechanism}

Wyatt [261] and Wyatt and Curry [202] have presented a quite remarkable "Stadium-wave" mechanism of a special and temporal wave of 4 segments propagating across the Northern Hemisphere activating a network of synchronized climate variables. They identified four temporal groups (I - IV) changing between negative and positive phases. It offers a synchronization and feedback coupling between ocean, ice and wind factors. In Appendix 1, it is shown that the "stadium wave" mechanism of Wyatt and Curry [202] can be combined with the planetary-solar modulation, Gulf Stream beat and the external rotation forces here discussed.

In this paper, we acknowledge that the mechanism seems to imply a logical manifestation of "terrestrial changes in climate \& environment" in Figure 9, but calls for external driving forces (as indicated in Figure 7 and Figure 9).

\section{Discussion}

The yearly cycle of freezing and melting of the Arctic Ocean ice cover depends on the variation of heat influx during the seasons. This is modulated by many different internal and/or external factors, as the direct solar radiation, the cloud cover modulated by cosmic ray particles and other particles (pollution or volcanic), transport of warm water by ocean currents and advection of air by the wind directed by pressure system, again modulated by the solar wind. Our working hypothesis is that the planetary gravity beat is somehow preserved as a weak signal through a chain of processes schematically shown in Figure 9 and in some cases amplified in local or regional synchronized systems: especially Earth rotation [36] [262] and the polar wobble [86].

The climate of the North Western coast of Europe and the position of the ice edge in the North Atlantic Ocean are controlled by the Northern branch of the Atlantic current (Gulf Stream) and by advection modulated by the Northern Jet Stream, which both are controlled by the solar wind. The solar wind also acts on the Earth's speed of rotation, which again forces the ocean currents (cf. Figure 7).

The summer Artic sea ice was nearly gone during the Holocene temperature maximum 10,500 to 5500 cal. yrs BP (Figure 11), but reappeared during the Late Holocene cooling period, which culminated with maximum ice in the period 1660-1720 as demonstrated in Figure 12. Thereafter a rapid warming took place in the $18^{\text {th }}$ century (in 1769 the ice edge was even north of Svalbard) before another cold period occurred around 1800-1818 (in agreement with stages 1 - 3 in Figure 21 solar wind reconstruction). From then on, we observe a successive northward shift of the ice edge (Figure 12).

The explorations of the Arctic that started late in the $16^{\text {th }}$ century led to the discovery of Svalbard and rich stocks of seals and bowhead whales (Balaeana mysticetus). By inspection of logbooks from expeditions and hunters and later from airplanes and satellites, it has been possible to estimate the BIE August position since 1579. This series is not complete, but it makes it possible to investi- 
gate secular trends, which are important to understand the evolution of the Arctic ice cover and Earth's climate.

When the BIE expanded during the cold $19^{\text {th }}$ century, and the stock had been hunted down, commercial whale hunting stopped. The bowhead disappeared (Figure 14). It came back in the 1990s when the BIE position retreated north of Svalbard (Figure 15).

The position of the Sea Ice Edge in the Barents Sea (BIE) is a result of many dynamic factors acting on different time scales. Signatures of periodic and quasi-periodic variations can give indications on relations preserved during a chain of processes as indicated in Figure 9 and Figure 18. Periods with much ice correspond to deep minima in the solar activity, suggesting a causal connection between solar activity and the BIE positions.

\subsection{The Maunder and Dalton Minima}

The Gulf Stream circulation system is strongly driven by the main alternations between Grand Solar Maxima and Minima (Figures 1-6, Figure 8, Figure 12, Figure 19). During the Maunder and Dalton Minima, the inflow of warm Atlantic water to the Arctic was strongly reduced, and cold Arctic water reached all the way south to central Portugal (Figure 5). In the GIN Sea region, severe climate conditions and periods of extensive ice expansion occurred (Figure 12). Both periods are well recorded in the Solar wind intensity record of Figure 21 (zones 1 and 3 ). The solar maximum of the $18^{\text {th }}$ century, is recorded in strongly intensified inflow of warm Atlantic water to the Arctic, high solar irradiance at $65^{\circ} \mathrm{N}$ (Figure 19), high values of solar wind (Figure 21, zone 3), and generally warm climate conditions and strongly reduced ice extension in the GIN Sea region with the April maximum ice edge of year 1769 located even north of Svalbard (Figure 12).

A particular problem with this interpretation is that the maximum catch of bowhead whales took place in the period 1685-1703 (Figure 14) when the coldest climate in the millennium was recorded in Europe, and the global sea surface temperature was $1.0^{\circ} \mathrm{C}-1.5^{\circ} \mathrm{C}$ cooler than in the $1950-1980$ period [65]. From Figure 15 and Figure 21 it is clear that the BIE moved north at least 50 years before the recent high solar wind level was reached. Gulf Stream circulation type-a dominated the $18^{\text {th }}$ century ([63], Fig. 7a in [64]). The water north of Svalbard and in the Fram Strait was apparently warm enough for rich marine life. This seems to call for a local source of heat or special wind pattern, maybe recorded in the weak positive NAO-index in 1705-1740 [263].

Another problem is that the high level of solar wind through the $19^{\text {th }}$ century did not move the BIE north. This did not happen until the start of the solar Grand Maximum in the 1920s, and was accompanied by a rapid temperature increase at many Arctic stations (Figure 13). One possible explanation will be explored in Paper 2 [136]: The Sun was stressed after the producing short sunspot-cycles resulting in the $18^{\text {th }}$ century maximum, and it relaxed by producing 
long cycles in the $19^{\text {th }}$ century. Only at the start of cycle 16 (1900) it was "refreshed" and able to produce short cycles [238]. This pushed the BIE north in the $20^{\text {th }}$ century, still modulated by the planetary cycles.

In the BIE position estimates (Figure 14) we find minimum ice 180 years apart, corresponding to the José period of alignment of the planets in the solar system. It may also seem significant that Yndestad and Solheim [92] were able to document the planetary beat of Jupiter, Saturn, Uranus and Neptune in TSI and sunspot datasets in addition to the recorded 210-yr (de Vries/Suess) cycle, which is the predominant cycle in the ${ }^{14} \mathrm{C}$ production record of the last 9400 years [47].

\subsection{The 60-Yr Cycle}

The most prominent feature in the BIE record (Figure 15) are the two deep minima 1630-1660 and 1800-1900 and gradual move north after 1900. A series of maxima 180 years apart suggest a modulation following the José cycle of orbital synchronization. Since this is a sum of three 60 -year cycles we may also find the 60-year cycle in the data (to be searched for in Paper 2 [136]).

A 60-year quasi-periodic cycle is detected in global temperature (Figure 19; [208] [239] [262] [264] [265]), in TSI [219], in LOD [36] [43] [266], in geomagnetism [267] [268], in Jet Stream changes between zonal and meriodional circulation [101] [269] [270], in sea level changes [271] [272] [273] [274] and ocean oscillations systems like PDO, AMO and NAO (Figure 18; [204]).

Scafetta (e.g. [244] [266]) and Solheim [239] showed that the 60-yr cycle had an origin in the combined 60-yr beat of Jupiter and Saturn. Consequently, we must place planetary beat-in this case the combined beat by Jupiter and Saturn-at the top of the forcing (Figure 9). This beat simultaneously affects the Sun, the Earth and the Earth-Moon system. The solar variability generates changes in luminosity (irradiance) and Solar Wind, the last one of which controls a number of fundamental Earth's processes as illustrated in Figure 9.

The planetary beat effects on Earth's rotation and the Earth-Moon system imply that there must also be a generation of tidal effects. It therefore seems significant that Yndestad was able to identify the 18.6 and 74.4 tidal cycles in different Norwegian Sea parameters [84] [250] [259] [260], and Hansen [248] was able to document the $55.8 \mathrm{yrs}$ and $74.4 \mathrm{yrs}$ tidal cycles in the North Sea and Kattegatt records.

\subsection{The Near Future}

Cyclic forcing functions imply that we would have means of predict changes in the near future. The deterministic model analyses of sunspots and TSI recorded by Yndestad and Solheim [92] suggest that we will have a new Dalton-type minimum by about 2025-2050 and 2040-2065, respectively. This fits well with other estimates of a New Grand Solar Minimum; e.g. at about 2030-2050 [37] [39], starting in 2014 and reaching its minimum in 2055-2060 [275]), in 2030-2040 [244] [276], and around 2040 [165]. 
The 60-yr cycle (Figure 19) and the lunar cycles must interact with the Gleissberg ( $~ 84$ years) and the de Vries/Suess (208 years) cycles as assumed in the concept of a New Grand Solar Minimum peaking some 20 - 30 years in the future (above). The effect of the positive trend of a millennium long cycle [235] should also be considered. It seems significant, however, that the combined Gleisssberg-de Vries cycles provides a cyclic trend which agrees well with the observed changes in ${ }^{14} \mathrm{C}$ prediction and the Gulf Stream beat between type-a and type-c circulation patterns ([38] [39]; Appendix 2).

\section{Conclusions}

We have presented a new 440 long record of the changes in BIE position (Figure 15). It includes an observed ice maximum in the mid $17^{\text {th }}$ century, extreme northern positions in the $18^{\text {th }}$ century and expansion to low latitudes in the early $19^{\text {th }}$ century. Since the end of the Dalton minimum about 1820, BIE is moving north with cycles imposed on a linear trend; slow in the beginning, faster after 1920. We correlated this with the changes in Gulf Stream beat with its major changes in inflow of Atlantic water to the Arctic; low inflow, cold climatic condition and ice expansion during the Maunder Minimum, strong inflow, warm climatic conditions and ice reduction during the Solar Maximum of the $18^{\text {th }}$ century, and cold climatic condition and ice expansion during the Dalton Minimum. This is consistent with a solar forcing where the changes in Earth's shielding strength play a central role. Much ice persisted during the $19^{\text {th }}$ century. Significant warming and ice melting are recorded during the $20^{\text {th }}$ and early $21^{\text {st }}$ centuries (except for a minor step back in 1940-1960).

This implies changes in solar wind, and an ultimate driving force in planetary beat (Figure 9). The planetary beat includes the interacting effects of Jupiter, Saturn, Uranus and Neptune on the 60-yrs, 84-yrs and 208-yrs cycles in addition to an integrated effect of almost two centuries of persistent high solar wind (Figure 21) or a long cycle perhaps of millennium length, driven by the combined outer planets, not to forget lunar cycles imposed by the polar wobble. Peaks (or ice minima) 180 years apart may be a result of planetary synchronization (the José cycle).

During the last 200 years, the BIE record seems predominantly forced by a long-period maybe of millennium scale steady northward move, and shorter cycles, and the 60 -yrs cycle, ultimately driven by the combined Jupiter and Saturn beat on the Sun, the Earth and the Earth-Moon system (Figure 9). This planetary beat seems also to be the external force needed to drive the "stadium wave" mechanism of Wyatt and Curry (202) as further discussed in Appendix 1.

We note signs suggesting the ending of the present warm period; e.g. 1) the long-term solar cycles, which have set the character of the terrestrial changes in climate during the last millennium (Figure 4), are in the stage of changing back to a new Grand Solar minimum [39], 2) the solar cycles record a progressive decrease in sunspot number of cycles 23 and 24,3 ) the atmospheric neutron count 
and solar wind speed have changed in the last decade (Figure 22) towards weaker shielding conditions, and 4) the Arctic Oceans are cooling in the last decade (Figure 10(A) and Figure 10(B)) and the North Atlantic is recording a freshening [99].

As for the future changes in climate and environment of the Arctic, there are two scenarios: 1) a linear, maybe even accelerating, warming leading to ice-free conditions in 2061-2088 according to Onarheim and Årthun [160], or 2) cyclic changes, in response to planetary beat leading to a New Grand Solar Minimum at about 2030-2050 with colder climatic conditions. Our data are in favour of the second scenario. The climatic evolution during the next couple of decades will provide the final test.

Finally, we note with pleasure that the bowhead whale (Balaeana mysticetus), once feared to have become extinct (Figure 14), has now reappeared.

\section{Acknowledgements}

This is our first report of the Barents Sea Ice Edge (BIE) project. It is a typical collaboration product. JES has acted as editor and contributed large parts of the text and figures, NAM has contributed large parts of the text and figures, $\mathrm{OH}$ is behind most of Section 6, and SFP is responsible for most of Section 7. None of the authors have any special funding for this project to declare. We declare no conflict of interest. Our second report will follow soon. It is entitled: Changes in Barents Sea Ice Edge Positions during the last 440 years. Sun, Moon or Planets [136]. Two supplementary notes (by NAM) are added to the paper as Appendix 1 and Appendix 2.

\section{Conflicts of Interest}

The authors declare no conflicts of interest regarding the publication of this paper.

\section{References}

[1] Scafetta, N. (2014) The Complex Planetary Synchronization Structure of the Solar System. Pattern Recognition in Physics, 2, 1-19. https://doi.org/10.5194/prp-2-1-2014

[2] Mörner, N.-A., Tattersall, R., Solheim, J.-E., et al. (2013) General Conclusions Regarding the Planetary-Solar-Terrestrial Interaction. Pattern Recognition in Physics, 1, 205-206. https://doi.org/10.5194/prp-1-205-2013

[3] Usoskin, I.G., Solanki, S.K. and Kovaltsov, G.A. (2007) Grand Minima and Maxima of Solar Activity: New Observational Constraints. Astronomy \& Astrophysics, 471, 301-309. https://doi.org/10.1051/0004-6361:20077704

[4] Ljungqvist, F.C. (2010) A New Reconstruction of Temperature Variability in the Extra-Tropical Northern Hemisphere during the Last Two Millenia. Geografiske Annaler, 92A, 339-351. https://doi.org/10.1111/j.1468-0459.2010.00399.x

[5] Pitman III, W.C. and Talwani, M. (1972) Sea Floor Spreading in the North Atlantic. Geological Society of America Bulletin, 83, 619-646. https://doi.org/10.1130/0016-7606(1972)83[619:SSITNA]2.0.CO;2 
[6] Talwani, M. and Eldholm, O. (1977) Evolution of the Norwegian-Greenland Sea. Geological Society of America Bulletin, 88, 969-999. https://doi.org/10.1130/0016-7606(1977)88<969:EOTNS>2.0.CO;2

[7] Mörner, N.-A. (1980) Earth Movements, Paleoceanography, Paleoclimatology and Eustasy: Major Cenozoic Events in the North Atlantic. Geologiska Föreningen $i$ Stockholm Förhandlingar, 102, 261-268. https://doi.org/10.1080/11035898009455168

[8] Hopkins, T.S. (1991) The GIN Sea-A Synthesis of Its Physical Oceanography and Literature Review 1972-1985. Earth-Science Reviews, 30, 175-318. https://doi.org/10.1016/0012-8252(91)90001-V

[9] Mosar, J., Lewis, G. and Torsvik, T.H. (2002) North Atlantic Sea-Floor Spreading Rates: Implications for the Tertiary Development of Inversion Structures of the Norwegian-Greenland Sea. Journal of the Geological Society, 159, 503-515. https://doi.org/10.1144/0016-764901-135

[10] Bijlsma, S. (1978) Sedimentation by Rivers from the Scandinavian Area in the Northwestern Part of the North Sea Basin. Abstracts, Meeting of the European Geological Societies II, Amsterdam, 27.

[11] Schlüter, H.U. and Hinz, K. (1979) The Continental Margin of West Spitsbergen. Zeitschrift der Deutschen Gesellschafrfiir Polarforschlung, 48, 151-169.

[12] Manum, S. (1962) Studies in the Tertiary Flora of Spitsbergen with Notes on Tertiary Floras of Ellesmere Island, Greenland and Iceland. Norsk Polarinsitutt, 125, 127.

[13] Clifton, A.J. (2012) The Eocene Flora of Svalbard and Its Climatic Significance. PhD Thesis, Leeds University, Leeds, $401 \mathrm{p}$.

[14] Denk, T., Wanntorp, L., Manum, S.B. and Haglund, O. (1999) Catalogue of Tertiary Plants from Spitsbergen Housed in the Swedish Museum of Natural History, Stockholm.

http://www.nrm.se/en/forskningochsamlingar/paleobiologi/publikationer/publikati oneraldre/bocker/catalogueofthetertiaryplantfossils.855.html

[15] Schmidt, D.N. (2007) The Closure History of the Panama Isthmus: Evidence from Isotopes and Fossils to Models and Molecules. In: Williams, M., Haywood, A.M., Gregory, J.F. and Schmidt, D.N., Eds., Deep Time Perspectives on Climate Change Marrying the Signal from Computer Models and Biological Proxies, Geological Society of London, Micropalaeontological Society Special Publication, London, 429-444.

[16] Marek, C. (2015) The Emergence of the Isthmus of Panama: A Biological Perspective. PhD Thesis, Justus-Liebig-Universität Giessen, Gießen, 216 p.

http://geb.uni-giessen.de/geb/volltexte/2016/11868/pdf/MarekCarina_2015_12_08.pdf

[17] Mörner, N.-A. (1993) Neotectonics. The Global Tectonic Regiment during the Last 3 ma and the Initiation of Ice Ages. Annals of the Brazilian Academy of Sciences, 65, 295-301.

http://tallbloke.wordpress.com/2012/12/08/nils-axel-morner-neotectonics-and-therecent-ice-ages/\#comment-37682

[18] Mörner, N.-A. (2019) Development of Ideas and New Trends in Modern Sea Level Research: The Pre-Quaternary, Quaternary, Present and Future. In: Ramkumar, M., et al., Eds., Coastal Zone Management. Global Perspectives, Regional Processes, Local Issues, Elsevier, Amsterdam, 13-62. https://doi.org/10.1016/B978-0-12-814350-6.00002-1

[19] Ruddiman, W.F. and Raymo, M.E. (1988) Northern Hemisphetre Climate Regimes during the Past 3 Ma: Possible Tectonic Connections. Philosophical Transactions of the Royal Society of London B, 318, 411-430. https://doi.org/10.1098/rstb.1988.0017 
[20] Maslin, M.A., Haug, G.H., Sarthein, M. and Tiedeman, R. (1996) The Progressive Intensification of Northern Hemisphere Glaciation as Seen from the North Pacific. Geologische Rundschau, 85, 452-465. https://doi.org/10.1007/BF02369002

[21] Lisiecki, L.E. and Raymo, M.E. (2005) A Pliocene-Pleistocene Stack of 57 Globally Distributed Bentic $\delta^{18} \mathrm{O}$ Records. Paleoceanography, 20, PA1003. https://doi.org/10.1029/2004PA001071

[22] Mearns, E. (2017) The Vostok Ice Core and the 14,000 Year $\mathrm{CO}_{2}$ Time Lag. Energy Matters, June 14. http://euanmearns.com/the-vostok-ice-core-and-the-14000-year-co2-time-lag

[23] Cravette, J. and Suc, J.P. (1981) Climate Evolution of North-Western Mediterranean Area during Pliocene and Early Pleistocene by Pollen-Analysis and Forams of Drill Autan 1. Chronostratigraphic Correlations. Pollen and Spores, 23, 247-258.

[24] Van Couvering, J.A. (1997) The Pleistocene Boundary and the Beginning of the Quaternary. World and Regional Geology Series No. 9, Cambridge Univ. Press, Cambridge, $589 \mathrm{p}$.

[25] Van Couvering, J.A. (2014) Quaternary Geology and Paleoenvironments. In: Henke, W. and Tattersall, I., Eds., Handbook of Paleoanthropology, Springer, Berlin, 537-555. https://doi.org/10.1007/978-3-642-39979-4_80

[26] Jakobsson, M., et al. (2014) Arctic Ocean Glacial History. Quaternary Science Reviews, 92, 40-67. https://doi.org/10.1016/j.quascirev.2013.07.033

[27] Kandiano, E., Werner, K., Müller, J. and Cronin, T.M. (2019) Editorial: Palaeocenographic Conditions in High Northern Latitudes during Quaternary Interglaciations. Frontiers in Earth Science, 7, 1-3. https://doi.org/10.3389/feart.2019.00207

[28] Pope, E.L., Talling, P.J., Hult, J.E., et al. (2016) Long-Term Record of Barents Sea Ice Sheet Advance to the Shelf Edge from a 140,000 Year Record. Quaternary Science Review, 150, 55-66. https://doi.org/10.1016/j.quascirev.2016.08.014

[29] Newton, A.M.W. and Huuse, M. (2017) Glacial Geomorphology of the Central Barents Sea: Implications for the Dynamic Deglaciation of the Barents Sea Ice Sheet. Marine Geology, 387, 114-131. https://doi.org/10.1016/j.margeo.2017.04.001

[30] Kurjanski, B., Rea, B.R., Spagnolo, M., et al. (2019) Morphological Evidence for Marine Ice Stream Shutdown, Central Barents Sea. Marine Geology, 415, 64-76. https://doi.org/10.1016/j.margeo.2019.05.001

[31] Stommel, H. (1958) The Gulf Stream: A Physical and Dynamical Description. University of California Press, Berkeley. https://doi.org/10.5962/bhl.title.34897

[32] Wunsch, C. (2002) What Is the Thermohaline Circulation? Science, 298, 1179-1181. https://doi.org/10.1126/science.1079329

[33] Wilkinson, J. (2010) History of the Gulf Stream. Keys Historeum, Historical Preservation Society of the Upper Keys, Key Largo.

[34] Rahmstorf, S. (2003) The Concept of Thermohaline Circulation. Nature, 421, 699. https://doi.org/10.1038/421699a

[35] Broecker, W.S. (1991) The Great Ocean Conveyor. Oceanography, 4, 79-89. https://doi.org/10.5670/oceanog.1991.07

[36] Mörner, N.-A. (1996) Global Change and Interaction of Earth Rotation, Ocean Circulation and Paleoclimate. The Anais da Academia Brasileira de Ciências, 68, 77-94.

[37] Mörner, N.-A. (2010) Solar Minima, Earth's Rotation and Little Ice Ages in the Past and in the Future: The North Atlantic-European Case. Global and Planetary Change, 72, 282-293. https://doi.org/10.1016/j.gloplacha.2010.01.004 
[38] Mörner, N.-A. (2011) Arctic Environment by the Middle of This Century. Earth \& Environment, 22, 207-218. https://doi.org/10.1260/0958-305X.22.3.207

[39] Mörner, N.-A. (2015) The Approaching New Grand Solar Minimum and Little Ice Age Climate Conditions. Natural Science, 7, 510-518.

https://doi.org/10.4236/ns.2015.711052

[40] Yasuhara, M., deMenocal, P.B., Dwyer, G.S., et al. (2019) North Atlantic Intermediate Variability over the Past 20,000 Years. Geology, 47, 659-663. https://doi.org/10.1130/G46161.1

[41] Thibodeau, B., Not, C., Zhu, J., et al. (2018) Last Century Warming over the Canadian Atlantic Shelves Linked to Weak Atlantic Meridional Overturning Circulation. Geophysical Research Letters, 45, 12,376-12,385.

https://doi.org/10.1029/2018GL080083

[42] Seidov, D., Mishonov, A., Reagan, J. and Parsons, R. (2017) Multidecadal Variability and Climate Shift in the North Atlantic Ocean. Geophysical Research Letters, 44, 4985-4993. https://doi.org/10.1002/2017GL073644

[43] Mörner, N.-A. (2013) Solar Wind, Earth's Rotation and Changes in Terrestrial Climate. Physical Review \& Research International, 3, 117-136.

[44] Easterbrook, D.J. (2016) Cause of Global Climate Changes: Correlation of Global Temperature, Sunspots, Solar Irradiance, Cosmic Rays, and Radiocarbon and Beryllium Production Rates. In: Easterbrook, D.J., Ed., Evidence-Based Climate Science, Second Edition, Elsevier, Amsterdam, 245-262.

https://doi.org/10.1016/B978-0-12-804588-6.00014-8

[45] Owens, M.J., Lockwood, M. and Riley, P. (2017) Global Solar Wind Variations over the Last Four Centuries. Scientific Reports, 7, Article No. 41548. https://doi.org/10.1038/srep41548

[46] Dergachev, V.A. and Vasiliev, S.S. (2019) Long-Term Changes in the Concentration of Radiocarbon and the Nature of the Hallstatt Cycle. Journal of Atmospheric and Solar-Terrestrial Physics, 182, 10-24. https://doi.org/10.1016/j.jastp.2018.10.005

[47] Abreu, J.A., Beer, J., Ferriz-Mas, A., McCracken, K.G. and Steinhilber, F. (2012) Is There a Planetary Influence on Solar Activity? Astronomy \& Astrophysics, 548, A88. https://doi.org/10.1051/0004-6361/201219997

[48] Easterbrook, D.J. (2019) The Solar Magnetic Cause of Climate Change and the Origin of the Ice Ages. Abstracts with Programs, 51, Article No. 210-11. https://doi.org/10.1130/abs/2019AM-336117

[49] Lamb, H.H. (1984) Climate History in Northern Europe and Elsewhere. In: Mörner, N.-A. and Karlén, W., Eds., Climate Change on a Yearly to Millennial Basis, Reidel Publ. Co., Dordrecht, 225-240. https://doi.org/10.1007/978-94-015-7692-5_24

[50] Pettersson, O. (1913) Klimatförändringar i historisk och förhistorisk tid. Kungliga Svenska Vetenskapsakademiens Handlingar, 51, 1-81.

[51] Mörner, N.-A. (1995) Earth Rotation, Ocean Circulation and Paleoclimate. GeoJournal, 37, 419-430. https://doi.org/10.1007/BF00806932

[52] Fisher, D.A., Koerner, R.M., Kuivinen, K., et al. (1966) Inter-Comparison of Ice Core $\delta^{18} \mathrm{O}$ and Precipitation Records from Sites in Canada and Greenland over the Last 3500 Years and over the Last Few Centuries in Detail Using EOF Techniques. NATO ASI Series, 141, 297-378. https://doi.org/10.1007/978-3-642-61113-1_15

[53] Barlow, L.K., Sadler, J.P., Ogilvie, A.E.J., et al. (1997) Interdisciplinary Investigations of the End of the Norse Western Settlement in Greenland. The Holocene, 7, 489-499. https://doi.org/10.1177/095968369700700411 
[54] Christiansen, H.H. (1995) Observations of Open System Pingos in a Marsh Environment, Mellemfjord, Disko, Central West Greenland. Danish Journal of Geography, 95, 42-48. https://doi.org/10.1080/00167223.1995.10649362

[55] Christiansen, H.H. (1997) Open System Pingos in Mellemfjord, Disko, Central West Greenland: A Reply to Gurney and Worsley. Danish Journal of Geography, 97, 157-159.

[56] Humlum, O. (1999) Late Holocene Climate in Central West Greenland: Meteorological Data and Rock Glacier Isotope Evidence. The Holocene, 9, 581-594. https://doi.org/10.1191/095968399671916949

[57] Bond, G., Showers, W., Cheseby, M., et al. (1997) A Pervasive Millennial-Scale Cycle in North Atlantic Holocene and Glacial Climates. Science, 278, 1257-1266. https://doi.org/10.1126/science.278.5341.1257

[58] Bond, G., Kromer, B., Beer, J., et al. (2001) Persistent Solar Influence on North Atlantic Climate during the Holocene. Science, 294, 2130-2136. https://doi.org/10.1126/science.1065680

[59] Barker, S., Knorr, G., Conn, S., et al. (2019 Early Interglacial Legacy of Deglacial Climate Instability. Paleoceanography and Paleoclimate, 34, 1455-1475. https://doi.org/10.1029/2019PA003661

[60] Bianchi, G.G. and McCave, I.N. (1999) Holocene Periodicity in North Atlantic Climate and Deep-Ocean Flow South of Iceland. Nature, 397, 515-517. https://doi.org/10.1038/17362

[61] Bard, E., Raisbeck, G., Yiou, F. and Jouzel, J. (2000) Solar Irradiance during the Last 1200 Years Based on Cosmogenic Nuclides. Tellus, 52B, 985-992. https://doi.org/10.3402/tellusb.v52i3.17080

[62] Sejrup, H.P., Lehman, S.L., Haflidason, H., et al. (2010) Response in Norwegian Sea Temperature to Solar Forcing since 1000 AD. Journal of Geophysical Research, 115, C12034. https://doi.org/10.1029/2010JC006264

[63] Mörner, N.-A. (2015) Multiple Planetary Influences on the Earth. In: Mörner, N.-A., Ed., Planetary Influence on the Sun and the Earth, and a Modern Book-Burning, Nova Science Publishers, New York, 39-50.

[64] Mörner, N.-A. (2019) Rotational Eustasy as Understood in Physics. International Journal of Geosciences, 10, 709-723. https://doi.org/10.4236/ijg.2019.106040

[65] Mazzarella, A. and Scafetta, N. (2018) The Little Ice Age Was 1-0-1.5 ${ }^{\circ} \mathrm{C}$ Cooler That Current Warm Period According to LOD and NAO. Climate Dynamics. https://doi.org/10.1007/s00382-018-4122-6

[66] Marsden, G.B. and Cameron, A.G.A. (1966) The Earth-Moon System. Plenum Press, New York

[67] Mörner, N.-A. (1992) Sea Level Changes and Earth's Rate of Rotation. Journal of Coastal Research, 8, 966-971.

[68] Mörner, N.-A. (1996) Earth Rotation, Ocean Circulation and Palaeoclimate: The North Atlantic-European Example. In: Andrews, J.T., Austin, W.E.N., Bergsten, H. and Jennings, A.E., Eds., Late Quaternary Palaeoceanography of the North Atlantic Margins, Geological Society Special Publication, London, Vol. 111, 359-370. https://doi.org/10.1144/GSL.SP.1996.111.01.24

[69] Kerr, R.A. (2000) A North Atlantic Climate Pacemaker for the Centuries. Science, 288, 1984-1985. https://doi.org/10.1126/science.288.5473.1984

[70] Bjerknes, J. (1964) Atlantic Air-Sea Interaction. Advances in Geophysics, 10, 1-82. https://doi.org/10.1016/S0065-2687(08)60005-9 
[71] Levitus, S. (1990) Interpendental Variability of Steric Sea Level and Geopotential Thickness on the North Atlantic Ocean, 1970-1974 versus 1955-1959. Journal of Geophysical Research (Oceans), 95, 5233-5238. https://doi.org/10.1029/JC095iC04p05233

[72] Lund, D.C., Lynch-Stieglitz, J. and Curry, W.B. (2006) Gulf Stream Density Structure and Transport during the Past Millennium. Nature, 444, 601-604. https://doi.org/10.1038/nature05277

[73] Humlum, O., Christiansen, H.H., Ballantyne, C.K., Mortensen, L.E., Stuart, F.M. and Stone, J.O. (2020) Weichselian Glaciation of the Faroe Islands.

[74] Mörner, N.-A. (2015) The Bölling/Alleröd-Younger Dryas Oscillations Modern Book-Burning. In: Mörner, N.-A., Ed., Planetary Influence on the Sun and the Earth, and a Modern Book-Burning, Nova Sci. Publ., New York, 79-90.

[75] Bucha, V. (1984) Mechanism for Linking Solar Activity to Weather-Scale Effects, Climate Changes and Glaciations in the Northern Hemisphere. In: Mörner, N.-A. and Karlén, W., Eds., Climate Changes on a Yearly to Millennial Basis, Reidel Publ. Co., Dordrecht, 415-448. https://doi.org/10.1007/978-94-015-7692-5_45

[76] Bucha, V. (1988) Influence of Solar Activity on Atmospheric Circulation Types. Analles Geophysucae, 6, 513-524.

[77] Kellogg, T.B. (1984) Late Glacial-Holocene High-Frequency Climate Changes in Deep-Sea Cores from the Denmark Straight. In: Mörner, N.-A. and Karlén, W., Eds., Climate Changes on a Yearly to Millennial Basis, Reidel Publ. Co., Dordrecht, 123-133. https://doi.org/10.1007/978-94-015-7692-5_12

[78] Dickson, R.R., Osborn, T.J., Hurrell, J.W., et al. (2000) The Arctic Ocean Response to the North Atlantic Oscillation. Journal of Climate, 15, 2671-2696. https://doi.org/10.1175/1520-0442(2000)013<2671:TAORTT>2.0.CO;2

[79] Forman, S.L., Maslowski, W., Andrews, J.T., et al. (2000) Researchers Explore Arctic Freshwater's Role in Ocean Circulation. EOS, Transactions, American Geophysical Union, 81, 169-174. https://doi.org/10.1029/00EO00114

[80] Humlum, O. (2002) Modelling Late 20th Century Precipitation in Nordenskiöld Land, Central Spitsbergen, Svalbard, by Geomorphic Means. Norwegian Geographical Journal, 56, 96-103. https://doi.org/10.1080/002919502760056413

[81] Jennings, A.E., Knudsen, K.L., Hald, M., Hansen, C.V. and Andrews, J.T. (2002) A Mid-Holocene Shift in Arctic Sea-Ice Variability on the East Greenland Shelf. The Holocene, 12, 49-58. https://doi.org/10.1191/0959683602hl519rp

[82] Meeker, L.D. and Mayewski, P.A. (2002) A 1400-Year High-Resolution Record of Atmospheric Circulation over the North Atlantic and Asia. The Holocene, 12, 257-266. https://doi.org/10.1191/0959683602hl542ft

[83] Vinje, T. and Goosse, H. (2004) Ice Extent Variations during Last Centuries. Proceedings of the ACYS Final Science Conference, St. Petersburg, 11-14 November 2003, TD No. 1232.

[84] Soon, W.H.-H. (2005) Variable Irradiance as a Plausible Agent for Multidecadal Variations in the Arctic-Wide Surface Air Temperature Record of the Past 130 Years. Geophysical Research Letters, 32, L16712. https://doi.org/10.1029/2005GL023429

[85] Divine, D.V. and Dick, C. (2006) Historical Variability of Sea Ice Edge Position in the Nordic Seas. Journal of Geophysical Research, 111, C01001.

https://doi.org/10.1029/2004JC002851 
[86] Yndestad, H. (2006) The Influence of the Lunar Nodal Cycle on Arctic Climate. ICES Journal of Marine Science, 63, 401-420. https://doi.org/10.1016/j.icesjms.2005.07.015

[87] Humlum, O., Elberling, B., Hormes, A., et al. (2005) Late Holocene Glacier Growth in Svalbard, Documented by Subglacial Relict Vegetation and Living Soil Microbes. The Holocene, 15, 396-407. https://doi.org/10.1191/0959683605hl817rp

[88] Humlum, O., Solheim, J.-E. and Stordahl, K. (2011) Spectral Analysis of the Svalbard Temperature Record 1912-2010. Advances in Meteorology, 2011, Article ID: 175296. https://doi.org/10.1155/2011/175296

[89] Sejrup, H.P., Haflidason, H. and Andrews, J.T. (2011) A Holocene North Atlantic SST Record and Regional Climate Variability. Quaternary Science Review, 30, 3181-3195. https://doi.org/10.1016/j.quascirev.2011.07.025

[90] Davis, A.S. and Brewer, S. (2011) A Unified Approach to Orbital, Solar, and Lunar Forcing Based on the Earth's Latitudinal Insolation/Temperature Gradient. Quaternary Science Reviews, 30, 1861-1874. https://doi.org/10.1016/j.quascirev.2011.04.016

[91] Solheim, J.-E., Stordahl, K. and Humlum, O. (2012) Solar Activity and Svalbard Temperatures. Advances in Meteorology, 2012, Article ID: 543146. https://doi.org/10.1155/2011/543146

[92] Yndestad, H. and Solheim, J.-E. (2017) The Influence of Solar System Oscillation on the Variability of the Total Solar Irradiance. New Astronomy, 51, 135-152. https://doi.org/10.1016/j.newast.2016.08.020

[93] Roy, I. (2018) Solar Cyclic Variability Can Modulate Winter Arctic Climate. Scientific Reports, 8, Article No. 4864. https://doi.org/10.1038/s41598-018-22854-0

[94] Årthun, M., Eldervik, T. and Smedsrud, L.H. (2019) The Role of Atlantic Heat Transport in Future Arctic Winter Sea Ice Loss. Journal of Climate, 32, 3327-3341. https://doi.org/10.1175/JCLI-D-18-0750.1

[95] Treloar, N.C. (2002) Luni-Solar Tidal Influences on Climate Variables. International Journal of Climatology, 22, 1527-1542. https://doi.org/10.1002/joc.783

[96] Yndestad, H., Turrell, W.R. and Ozhigin, V. (2008) Lunar Nodal Tide Effects on Variability of Sea Level, Temperature, Salinity in the Faroe-Shetland Channel and the Barents Sea. Deep-Sea Research I, 55, 1201-1217. https://doi.org/10.1016/j.dsr.2008.06.003

[97] Humlum, O. (2019) Climate4you Update September 2019. http://www.climate4you.com

[98] Mörner, N.-A. (2020) Ocean Temperature Changes and Sea Level Changes. EXamines in Marine Biology \& Oceanography, 3, EIMBO.000568.2020.

[99] Holliday, N.P., et al. (2020) Ocean Circulation Causes the Largest Freshening Event for 120 Years in Eastern Subpolar North Atlantic. Nature Communications, 11, 585. https://doi.org/10.1038/s41467-020-14474-y

[100] Bryden, H.L., Johns, W.E., King, B.A., McCarthy, G., McDonagh, E.L., Moat, B.I. and Smeed, D.A. (2020) Reduction in Ocean Heat Transport at $26{ }^{\circ} \mathrm{N}$ since 2008 Cools the Eastern Subpolar Gyre of the North Atlantic. Journal of Climate, 33, 1677-1689. https://doi.org/10.1175/JCLI-D-19-0323.1

[101] Veretenenko and Ogurtsov, M. (2012) Regional and Temporal Variability of Solar Activity and Galactic Cosmic Ray Effects on the Lower Atmospheric Circulation. Advances in Space Research, 49, 770-783. https://doi.org/10.1016/j.asr.2011.11.020 
[102] McCracken, K.G., Beer, J. and Steinhilber, F. (2014) Evidence for Planetary Forcing of the Cosmic Ray Intensity and Solar Activity throughout the Past 9400 Years. Solar Physics, 289, 3207-3229. https://doi.org/10.1007/s11207-014-0510-1

[103] Johnsen, S.J., Clausen, H.B., Dansgaard, W., et al. (1992) Irregular Glacial Interstadials Recorded in the New Greenland Ice Core. Nature, 359, 311-313. https://doi.org/10.1038/359311a0

[104] Grootes, P.M., Stuiver, M., White, J.W.C., Johnsen, S.J. and Jouzel, J. (1993) Comparison of the Oxygen Isotope Records from the GISP2 and GRIP Greenland Ice Cores. Nature, 366, 552-554. https://doi.org/10.1038/366552a0

[105] Severinghaus, J.P., Sowers, T., Brook, E., Alley, R.B. and Bender, M.L. (1998) Timing of Abrupt Climate Change at the End of the Younger Dryas Interval from Thermally Fractionated Gases in Polar Ice. Nature, 391, 141-146. https://doi.org/10.1038/34346

[106] Hammer, C.U., Clausen, H.B. and Langway, C.C. (1997) 50,000 Years of Recorded Global Volcanisms. Climatic Change, 35, 1-15. https://doi.org/10.1023/A:1005344225434

[107] Berger, A. and Loutré, M.F. (1991) Insolation Values for the Climate of the Last 10 Million Years. Quaternary Science Reviews, 10, 297-317. https://doi.org/10.1016/0277-3791(91)90033-Q

[108] Bradley, R.S. (1990) Holocene Paleoclimatology of the Queen Elizabeth Islands, Canadian High Arctic. Quaternary Science Reviews, 9, 365-384. https://doi.org/10.1016/0277-3791(90)90028-9

[109] Andreev, A.A., Manley, W.F., Ingólfsson, Ó. and Forman, S.L. (2001) Environmental Changes on Yugorski Peninsula, Kara Sea, Russia, during the Last 12.800 Radiocarbon Years. Global and Planetary Change, 31, 255-264. https://doi.org/10.1016/S0921-8181(01)00123-0

[110] Birks, H.H. (1991) Holocene Vegetational History and Climatic Change in West Spitsbergen-Plant Macrofossils from Skardtjørna. The Holocene, 1, 209-218. https://doi.org/10.1177/095968369100100303

[111] Furrer, G., Stapfer, A. and Glaser, U. (1991) Zurnacheiszeitlichen Gletschergeschichte des Liefdefjords (Spitzbergen) (Ergebnisse der Geowissenschaftlichen Spizbergenexpedition 1990). Geographica Helvetica, 1991, 147-155. https://doi.org/10.5194/gh-46-147-1991

[112] Furrer, G. (1992) Zur Gletschergeschichte des Liefdefjords. Stuttgarter Geographische Studien, 117, 267-278.

[113] Furrer, G. (1994) Zur Gletschergeschichte des Liefdefjords/NW-Spizbergen. Zeitschrift für Geomorphologie, 97, 43-47.

[114] Salvigsen, O., Forman, S.L. and Miller, G.H. (1992) Thermophilous Molluscs on Svalbard during the Holocene and Their Paleoclimatic Implications. Polar Research, 11, 1-10. https://doi.org/10.1111/j.1751-8369.1992.tb00407.x

[115] Salvigsen, O. (2002) Radiocarbon-Dated Mytilus edulis and Modiolus modiolus from Northern Svalbard: Climatic Implications. Norwegian Journal of Geography, 56, 56-61. https://doi.org/10.1080/002919502760056350

[116] Koç, N., Jansen, E. and Haflidason, H. (1993) Paleoceanographic Reconstructions of Surface Ocean Conditions in the Greenland, Iceland and Norwegian Seas through the Last 14 Ka Based on Diatoms. Quaternary Science Reviews, 12, 115-140. https://doi.org/10.1016/0277-3791(93)90012-B 
[117] Hjort, C., Mangerud, J., Andrielsson, L., et al. (1996) Radiocarbon Dated Common Mussel Mytilus edulis from Eastern Svalbard and the Holocene Marine Climatic Optimum. Polar Research, 14, 239-243. https://doi.org/10.3402/polar.v14i2.6665

[118] Wohlfarth, B., Lemdahl, G., Olsson, S., et al. (1995) Early Holocene Environment on Bjørnøya (Svalbard) Inferred from Multidisciplinary Lake Sediment Studies. Polar Research, 14, 253-275. https://doi.org/10.3402/polar.v14i2.6667

[119] Svendsen, J.I. and Mangerud, J. (1997) Holocene Glacial and Climatic Variations on Spitsbergen, Svalbard. The Holocene, 7, 45-57. https://doi.org/10.1177/095968369700700105

[120] Lubinski, D.J., Forman, S.L. and Miller, G.H. (1999) Holocene Glacier and Climate Fluctuations on Franz Josef Land, Arctic Russia, $80{ }^{\circ} \mathrm{N}$. Quaternary Science Reviews, 18, 85-108. https://doi.org/10.1016/S0277-3791(97)00105-4

[121] Snyder, J.A., Werner, A. and Miller, G.H. (2000) Holocene Cirque Glacier Activity in Western Spitsbergen, Svalbard: Sediment Records from Proglacial Linnévatnet. The Holocene, 10, 555-563. https://doi.org/10.1191/095968300667351697

[122] Røthe, T.O., Bakke, J., Vasskog, K., et al. (2015) Arctic Holocene Glacier Fluctuations Reconstructed from Lake Sediments at Mitrahalvøya, Spitsbergen. Quaternary Science Reviews, 109, 111-125. https://doi.org/10.1016/j.quascirev.2014.11.017

[123] Røthe, T.O., Bakke, J., Støren, E.W.N. and Bradley, R.S. (2018) Reconstructing Holocene Glacier and Climate Fluctuations from Lake Sediments in Vårfluesjøen, Northern Spitsbergen. Frontiers in Earth Science, 6, 91. https://doi.org/10.3389/feart.2018.00091

[124] Van der Bilt, W.G.M., Bakke, J., Vasskog, K., et al. (2015) Reconstruction of Glacier Variability from Lake Sediments Reveals Dynamic Holocene Climate in Svalbard. Quaternary Science Reviews, 126, 201-218. https://doi.org/10.1016/j.quascirev.2015.09.003

[125] Van der Bilt, W.G.M., D’Andrea, W.J., Bakke, J., et al. (2018) Alkenone-Based Reconstruction Reveal Four-Phase Holocene Temperature Evolution for High Arctic Svalbard. Quaternary Science Reviews, 183, 204-213. https://doi.org/10.1016/j.quascirev.2016.10.006

[126] Mangerud, J. and Svendsen, J.I. (2018) The Holocene Thermal Maximum around Svalbard, Arctic North Atlantic; Molluscs Show Early and Exceptional Warmth. The Holocene, 28, 65-83. https://doi.org/10.1177/0959683617715701

[127] de Wet, G., Balascio, N.L., D’Andrea, W.J., et al. (2018) Holocene Glacier Activity Constructed from Proglacial Lake Gjøavatnet on Amsterdamøya, NW Svalbard. Quaternary Science Reviews, 183, 188-203. https://doi.org/10.1016/j.quascirev.2017.03.018

[128] Bakke, J., Balascio, N., van der Bilt, W.G., et al. (2018) The Island of Ameterdamøya: A Key Site for Studying Past Climate in the Arctic Archipelago of Svalbard. Quaternary Science Reviews, 183, 157-163. https://doi.org/10.1016/j.quascirev.2017.11.005

[129] Werner, K., Müller, J., Husum, K., et al. (2016) Holocene Sea Surface and Surface Water Masses in the Fram Strait-Comparisons of Temperature and Se-Ice Reconstructions. Quaternary Science Review, 147, 194-209. https://doi.org/10.1016/j.quascirev.2015.09.007

[130] Humlum, O. (2000) Grønland i Nordatlanten. In: Atlas over Grønland, Royal Danish Geographical Society, Copenhagen, 8-9.

[131] Velichko, A.A., Andreev, A.A. and Klimanov, V.A. (1997) The Dynamics of Climate and Vegetation in the Tundra and Forest Zone during the Late Glacial and Holocene. 
Quaternary International, 41/42, 71-96. https://doi.org/10.1016/S1040-6182(96)00039-0

[132] Lamb, H.H. (1977) Climate: Present, Past and Future. Methuen, London, 835 p.

[133] Lamb, H.H. (1979) Climate Variations and Changes in the Wind and Ocean Circulation: The Little Ice Age in the Northeast Atlantic. Quaternary Research, 11, 1-20. https://doi.org/10.1016/0033-5894(79)90067-X

[134] Lamb, H.H. (1982) Climate History and Modern World. Methuen, London, 387 p.

[135] Lamb, H.H. (1984) Some Studies of Little Ice Ages of Recent Centuries and Its Great Storms. In: Mörner, N.-A. and Karlén, W., Eds., Climate Change on a Yearly to Millennial Basis, Reidel Publ. Co., Dordrecht, 309-329. https://doi.org/10.1007/978-94-015-7692-5_34

[136] Solheim, J.-E., Humlum, O., Falk-Petersen, S. and Mörner, N.-A. (2020) Changes in Barents Sea Ice Edge Positions during the Last 440 Years: Sun, Moon or Planets.

[137] Lamb, H.H. (1995) Climate, History and the Modern World. Routledge, London, $433 \mathrm{p}$.

[138] Mutal, A., Spielhagen, R.F., Kazarina, G., et al. (2018) Warm-Water Events in the Eastern Fram Strait during the Last 2000 Years as Revealed by Different Microfossil Groups. Polar Research, 37, Article ID: 1540243. https://doi.org/10.1080/17518369.2018.1540243

[139] Nordli, Ø. and Kohler, J. (2003) The Early 20th Warming. Daily Observations at Green Harbour, Grønnefjorden, Spitsbergen. Norwegian Meteorological Institute, Report No. 12/03, 20 p.

[140] Hanssen-Bauer, I. and Førland, E.J. (1998) Long-Term Trends in Precipitation and Temperature in the Norwegian Arctic: Can They Be Explained by Changes in Atmospheric Circulation Patterns? Climate Research, 19, 143-153. https://doi.org/10.3354/cr010143

[141] Khrol, V.P. (1992) Atlas of the Energy Budget of the Northern Polar Region. L. Gidrometeoizdat, $52 \mathrm{p}$.

[142] Khrol, V.P. (1999) New Climatic Data on Water and Energy Balance of the Northern Polar Region. Russian Meteorology and Hydrology, 5, 42-48.

[143] Vilhjálmsson, H. and Jakobsson, J. (1998) Relation between Environmental Fluctuations and Fisheries Management. North Atlantic Climate Impacts. International Workshop on Environmental and Climate Variations and Their Impact in the North Atlantic Region, Reykjavik, 23-26 September 1998, 28.

[144] Taracouzio, T.A. (1938) Soviets in the Arctic. An Historical, Economical and Political Study of the Soviet Advance into the Arctic. The Macmillian Company, New York, $563 \mathrm{p}$.

[145] Huan, C. (1958) Le raid du croiseur "Sheer" au nord de la Sibérie. Revue Maritime, 141, 156-178.

[146] Barr, W. (1975) Operation "Wunderland": Admiral Scheer in the Kara Sea, August 1942. Polar Record, 17, 461-472. https://doi.org/10.1017/S0032247400032447

[147] Eyssen, R. (2002) HSK Komet. Kaperfahrt auf allen Meeren. Koehlers Verlagsgesellschaft $\mathrm{mbH}$, Hamburg, $264 \mathrm{p}$.

[148] Ahlmann, H.W. (1953) Glacier Variations and Climatic Fluctuations. American Geographical Society, New York, Bowman Memorial Lectures, 51 p.

[149] Houghton, J.T., Ding, Y., Griggs, D.J., Noguer, M., et al. (2001) Climate Change 2001: The Scientific Basis. Contribution of Working Group I to the Third Assess- 
ment Report of the Intergovernmental Panel on Climate Change. Cambridge University Press, Cambridge, $881 \mathrm{p}$.

[150] Førland, E.J., Hanssen-Bauer, I. and Nordli, P.Ø. (1997) Climate Statistics \& Long-Term Series of Temperature and Precipitation at Svalbard and Jan Mayen. Det Norske Meteorologiske Institutt, Report No. 21/97 klima, 72 p. https://doi.org/10.2166/nh.1997.0002

[151] Nordli, Ø., Przybylak, R., Ogilvie, A. and Isaksen, K. (2014) Long-Term Temperature Trends and Variability on Spitsbergen: The Extended Svalbard Airport Temperature Series, 1898-2012. Polar Research, 33, Article No. 21349. https://doi.org/10.3402/polar.v33.21349

[152] Pavlov, A.K., Tverberg, V., Ivanov, B.V., et al. (2013) Warming of Atlantic Water in Two West Spitsbergen Fjords over the Last Century (1912-2009). Polar Research, 32, Article No. 11206. https://doi.org/10.3402/polar.v32i0.11206

[153] Polyakov, I.V., Proshutinsky, A.Y. and Johnson, M.A. (1999) Seasonal Cycles in Two Regimes of Arctic Climate. Journal of Geophysical Research, 104, 25761-25788. https://doi.org/10.1029/1999JC900208

[154] Benestad, R.E., Hanssen-Bauer, I., Skaugen, T.E. and Førland, E.J. (2002) Associations between Sea-Ice and the Local Climate on Svalbard. Norwegian Meteorological Institute Report No. 07/02, 1-7.

[155] Shapiro, I., Colony, R. and Vinje, T. (2003) April Sea Ice Extent in the Barents Sea, 1850-2001. Polar Research, 22, 5-10. https://doi.org/10.3402/polar.v22i1.6437

[156] Mette, M.J., Wanamaker, A.D., Caroll, M.L., Ambrose Jr., W.G. and Retelle, M.J. (2015) Linking Large-Scale Climate Variability with Arctica islandica Shell Growth and Geochemistry in Northern Norway. Limnology and Oceanography, 61, 748-764. https://doi.org/10.1002/lno.10252

[157] Hulme, M., Barrow, E.M., Arnell, E.M., Harrison, P.A., Downing, T.E. and Johns, T.C. (1999) Relative Impacts of Human-Induced Climate Change and Natural Variability. Nature, 397, 688-691. https://doi.org/10.1038/17789

[158] Chambers, F.M. and Brain, S.A. (2002) Paradigm Shifts in Late-Holocene Climatology? The Holocene, 12, 239-249. https://doi.org/10.1191/0959683602hl540fa

[159] McCusker, K.E., Frey, J.C. and Sigmond, M. (2016) Twenty-Five Winters of Unexpected Eurasian Cooling Unlikely Due to Arctic Sea-Ice Loss. Nature Geoscience, 9 , 838-842. https://doi.org/10.1038/ngeo2820

[160] Onarheim, I.H. and Årthun, M. (2017) Toward an Ice-Free Barents Sea. Geophysical Research Letters, 44, 8387-8395. https://doi.org/10.1002/2017GL074304

[161] McLaren, A., Walsh, J.E., Bourke, R.H., Weaver, R.L. and Wrttmann, W. (1992) Variability in Sea-Ice Thickness over the North Pole from 1977 to 1990. Nature, 358, 224-226. https://doi.org/10.1038/358224a0

[162] Rothrock, D., Yanling, Y. and Maykut, G. (1999) Thinning of the Arctic Sea-Ice Cover. Geophysical Research Letters, 26, 3469-3472. https://doi.org/10.1029/1999GL010863

[163] Winsor, P. (2001) Arctic Sea Ice Thickness Remained Constant during the 1990s. Geophysical Research Letters, 24, 1039-1041. https://doi.org/10.1029/2000GL012308

[164] Polyakov, I.V., Pnyushkov, A.V., Alkire, M.B., et al. (2017) Greater Role for Atlantic Inflows on Sea-Ice Loss in the Eurasian Basin of the Arctic Ocean. Science, 356, 285-291. https://doi.org/10.1126/science.aai8204 
[165] Klyashtorin, L.B., Borisov, V. and Lyubshin, A. (2009) Cyclic Changes of Climate and Major Commercial Stocks of the Barents Sea. Marine Biology Research, 5, 4-17. https://doi.org/10.1080/17451000802512283

[166] Weydmann, A., Walczowski, W., Carstensen, J. and Kwasniewski, S. (2018) Warming of Subarctic Waters Accelerates Development of a Key Marine Zooplankton Calanus finmarchius. Global Change Biology, 24, 172-183. https://doi.org/10.1111/gcb.13864

[167] Cohen, J.H., Berge, J., Moline, M.A., et al. (2015) Is Ambient Light during the High Arctic Polar Night Sufficient to Act as a Visual Cue for Zooplankton? PLoS ONE, 10, e0126247. https://doi.org/10.1371/journal.pone.0126247

[168] Falk-Petersen, S., Hop, H., Budgell, W.P., et al. (2000) Physical and Ecological Processes in the Marginal Ice Zone of the Northern Barents Sea during the Summer Melt Periods. Journal of Marine Systems, 27, 131-159.

https://doi.org/10.1016/S0924-7963(00)00064-6

[169] Falk-Petersen, S., Timofeev, S., Pavlov, V. and Sargent, J.R. (2007) Climate Variability and Possible Effects on Arctic Food Chains: The Role of Calanus. In: Ørbæk, J.B., Tombre, T., Kallenborn, R., Hegseth, E., Falk-Petersen, S. and Hoel, A.H., Eds., Arctic Alpine Ecosystems and People in a Changing Environment, Springer Verlag, Berlin, 147-166. https://doi.org/10.1007/978-3-540-48514-8_9

[170] Arrigo, K.R., van Dijken, G. and Pabi, S. (2008) Impact of a Shrinking Arctic Ice Cover on Marine Primary Production. Geophysical Research Letters, 35, L19603. https://doi.org/10.1029/2008GL035028

[171] Søreide, J.E., Leu, E., Berge, J., Graeve, M. and Falk-Petersen, S. (2010) Timing of Blooms, Algal Food Quality and Calanus glacialis Reproduction and Growth in a Changing Arctic. Global Change Biology, 16, 3154-3163. https://doi.org/10.1111/j.1365-2486.2010.02175.x

[172] Leu, E., Søreide, J.E., Hessen, D.O., Falk-Petersen, S. and Berge, J. (2011) Consequences of Changing Sea-Ice Cover for Primary and Secondary Producers in the European Arctic Shelf Seas: Timing, Quantity, and Quality. Progress in Oceanography, 90, 18-32. https://doi.org/10.1016/j.pocean.2011.02.004

[173] Daase, M., Falk-Petersen, S., Varpe, Ø., et al. (2013) Timing of Reproductive Events in the Marine Copepod Calanus glacialis: A Pan-Arctic Perspective. Canadian Journal of Fisheries and Aquatic Sciences, 70, 871-884. https://doi.org/10.1139/cjfas-2012-0401

[174] Renaud, P.E., Daase, M., Banas, N., et al. (2018) Pelagic Food-Webs in a Changing Arctic: A Trait-Based Perspective Suggests a Mode of Resilience. ICES Journal of Marine Science, 75, 1871-1881. https://doi.org/10.1093/icesjms/fsy063

[175] Bogstad, B., Gjøsæter, H., Haug, T. and Lindstrøm, U. (2015) A Review of the Battle for Food in the Barents Sea: Cod vs Marine Mammals. Frontiers in Ecology and Evolution, 3, 591-615. https://doi.org/10.3389/fevo.2015.00029

[176] Haug, T., Bogstad, B., Chierici, M., et al. (2017) Future Harvest of Living Resources in the Arctic Ocean North of the Nordic and Barents Seas: A Review of Possibilities and Constraints. Fisheries Research, 188, 38-57. https://doi.org/10.1016/j.fishres.2016.12.002

[177] Divine, D., Isaksson, E., Martma, T., et al. (2011) Thousand Years of Winter Surface Air Temperature Variations in Svalbard and Northern Norway Reconstructed from Ice-Core Data. Polar Research, 30, 7379. https://doi.org/10.3402/polar.v30i0.7379

[178] Falk-Petersen, S., Pavlov, V., Cottier, F., et al. (2015) At the Rainbow's End-Productivity Hotspots Due to Upwelling along Arctic Shelves. Polar Biology, 38, 5-11. https://doi.org/10.1007/s00300-014-1482-1 
[179] Jonsson, J. (1994) Fisheries off Iceland, 1600-1900. ICES Marine Science Symposia, 198, 3-16.

[180] Vinje, T. (1999) Barents Sea Ice Edge Variation over the Past 400 Years. Workshop on Sea-Ice Charts of the Arctic, Seattle, WMO/TD No. 949, 4-6.

[181] Sverdrup, H.U. and Soule, M. (1933) Scientific Results of the "Nautilus" Expedition, 1931. Papers in Physical Oceanography and Meteorology. Massachusetts Institute of Technology and Woodshole Oceanographic Institutions II (I).

[182] Falk-Petersen, S., Mayzaud, P. and Kattner, G. (2009) Lipids, Life Strategy and Trophic Relationships of Calanus hyperboreus, C. glacialis and C. finmarchicus in the Arctic. Marine Biology Research, 5, 18-39. https://doi.org/10.1080/17451000802512267

[183] Allen, R.C. and Keay, I. (2006) Bowhead Whales in the Eastern Arctic, 1611-1911: Population Reconstruction with Historical Whaling Records. Environmental History, 12, 89-113. https://doi.org/10.3197/096734006776026791

[184] Weslawski, J.M., Hacquebord, L., Stempniewicz, L. and Malinga, M. (2000) Greenland Whales and Walruses in the Svalbard Food Web before and after Exploitation. Oceanologia, 42, 7-56.

[185] Vacquié-Garcia, J., Lydersen, C., Marques, T.A., et al. (2017) Late Summer Distribution and Abundance of Ice-Associated Whales in the Norwegian High Arctic. Endangered Species Research, 32, 59-70. https://doi.org/10.3354/esr00791

[186] Lowry, L.L. and Frost, K.J. (1984) Food and Feeding of Bowhead Whales in Western and Northern Alaska. Scientific Reports of the Whales Research Institute, Tokyo, Vol. 35, 1-10.

[187] Walkusz, W., Williams, W.J., Harwood, L.A., et al. (2012) Composition, Biomass and Energetic Content of Biota in the Vicinity of Feeding Bowhead Whales (Balaena mysticetus) in the Cape Bathurst Upwelling Region (South Eastern Beaufort Sea). Deep Sea Research Part I: Oceanographic Research Papers, 69, 25-35. https://doi.org/10.1016/j.dsr.2012.05.016

[188] Henrat, P. (1984) French Naval Operations in Spitsbergen during Louis XIV's Reign. Arctic, 37, 544-551. https://doi.org/10.14430/arctic2237

[189] Iversen, T. (1923) Torskefiske i gamle dager ved Spitsbergen. Torskeperioder. Norsk Fiskeritidene, 115-129.

[190] Nakken, O. (1998) Past, Present and Future Exploitation and Management of Marine Resources in the Barents Sea and Adjacent Areas. Fisheries Research, 37, 23-35. https://doi.org/10.1016/S0165-7836(98)00124-6

[191] Iversen, T. (1934) Some Observations on Cod in Northern Waters. Fiskeridirektorates skrifter, 4, 1-35.

[192] Hamre, J. (1988) Some Aspects of the Interrelation between the Herring in the Norwegian Sea and the Stock of Capelin and Cod in the Barents Sea. ICES CM Documents, 1988/H:42.

[193] Årthun, M., Eldevik, T., Viste, E., et al. (2017) Skilful Prediction of Northern Climate Provided by the Ocean. Nature Communications, 8, Article No. 15875. https://doi.org/10.1038/ncomms15875

[194] Drinkwater, K.F. (2005) The Response of Atlantic Cod (Gadus morhua) to Future Climate Change. ICES Journal of Marine Science, 62, 1327-1337. https://doi.org/10.1016/j.icesjms.2005.05.015

[195] Jensen, A.S. and Hansen, P.M. (1931) Investigations on the Greenland Cod (Gadus callarias) with an Introduction on the History of the Greenland Cod Fishery. ICES Rapports et Proces-Verbanx des Reunions, 72, 1-41. 
[196] Hansen, P.M. (1949) Studies on the Biology of the Cod in Greenland Waters. Conseil Permanent International Pour l'exploration de la mer. Andr. Fred. Høst \& Files, Copenhagen.

[197] Buch, E., Pedersen, S.A. and Ribergaard, M.H. (2004) Ecosystem Variability in West Greenland Waters. Journal of Northwest Atlantic Fishery Science, 34, 13-28. https://doi.org/10.2960/J.v34.m479

[198] Aune, M., Aniceto, A.S., Biuw, M., et al. (2018) Seasonal Ecology in Ice-Covered Arctic Seas Considerations for Spill Response Decision Making. Marine Environmental Research, 141, 275-288. https://doi.org/10.1016/j.marenvres.2018.09.004

[199] Geoffroy, M., Daase, M., Cusa, M., et al. (2019) Seasonality in Mesopelagic Sound Scattering Layers of the High Arctic: Variations in Biomass, Species Assemblage, and Trophic Relationships. Frontiers in Marine Science, 6, 1-18.

https://doi.org/10.3389/fmars.2019.00364

[200] José, P.D. (1965) Sun's Motion and Sunspots. Astronomical Journal, 70, 193-200. https://doi.org/10.1086/109714

[201] Wilson, I.R.G. (2011) Are Changes in the Earth's Rotation Rate Externally Driven and Do They Affect Climate? The General Science Journal, 3812, 1-31.

http://www.gsjournal.net/Science-Journals/Research\%20Papers-Astrophysics/Down $\underline{\text { load } / 3811}$

[202] Wyatt, M.G. and Curry, J.A. (2014) Role of Eurasian Arctic Shelf Sea Ice on a Secularly Varying Hemispheric Climate Signal during the 20th Century. Climate Dynamics, 42, 2763-2782. https://doi.org/10.1007/s00382-013-1950-2

[203] Easterbrook, D.J. and Kovanen, D.J. (2000) Cyclic Variations of Mt. Baker Glaciers in Response to Climate Changes and Their Correlation with Periodic Oceanographic Changes in Northeast Pacific Ocean. Geol. Soc. America, Abstracts with Program 32,17 .

[204] D’Aleo, J.S. and Easterbrook, D.J. (2016) Relationship of Multidecadal Global Temperatures to Multidecadal Ocean Oscillations. In: Easterbrook, D.J., Ed., Evidence-Based Climate Change, Second Edition, Elsevier, Amsterdam, 191-214. https://doi.org/10.1016/B978-0-12-804588-6.00011-2

[205] Polyakova, E.I, Journel, A.G., Polyakov, I.V. and Ghatt, U.S. (2006) Changing Relationship between the North Atlantic Oscillation and Key North Atlantic Climate Parameters. Geophysical Research Letters, 33, L03711. https://doi.org/10.1029/2005GL024573

[206] Lansner, F. and Pedersen, J.O.P. (2018) Temperature Trends with Reduced Impact of Ocean Air Temperature. Energy \& Environment, 29, 613-632. https://doi.org/10.1177/0958305X18756670

[207] Enfield, D.B., Mestas-Nunez, A.M. and Trimble, P.J. (2001) The Atlantic Multidecadal Oscillation and Its Relationship to Rainfall and River Flows in the Continental U.S. Geophysical Research Letters, 28, 2077-2080. https://doi.org/10.1029/2000GL012745

[208] Schlesinger, M.E. and Ramankutty, N. (1994) An Oscillation in the Global Climate System of Period 65-70 Years. Nature, 367, 723-726.

https://doi.org/10.1038/367723a0

[209] Alheit, J., Licandro, P., Coombs, S., et al. (2014) Reprint of "Atlantic Multidecadal Oscillation (AMO) Modulates Dynamics of Small Pelagic Fishes and Ecosystem Regime Shifts in the Eastern North and Central Atlantic". Journal of Marine Systems, 133, 88-102. https://doi.org/10.1016/j.jmarsys.2014.02.005 
[210] Klyashtorin, L.B. and Lyubushin, A.A. (2007) Cyclic Climate Change and Fish Productivity. VNIRO Publishing, Moscow, 223 p.

[211] Nikolaev, Y.V. and Alexeev, G.V. (1989) Structures and Variability of Large-Scale Oceanologic Processes and Fields in the Norwegian Energetically Active Zone. Gidrometteoizdat Publ. Ltd., Moscow, 128 p. (In Russian)

[212] Connolly, R., Connolly, M. and Soon, W. (2017) Re-Calibration of Arctic Sea Ice Extent Datasets Using Arctic Surface Air Temperature Records. Hydrological Sciences Journal, 62, 1317-1340. https://doi.org/10.1080/02626667.2017.1324974

[213] Onarheim, I.H., Smedsrud, L.H., Ingvaldsen, R.B. and Nilsen, F. (2014) Loss of Sea Ice during Winther North of Svalbard. Tellus A: Dynamic Meteorology and Oceanography, 66, 23933. https://doi.org/10.3402/tellusa.v66.23933

[214] Soon, W., Connolly, R. and Connolly, M. (2015) Re-Evaluating the Role of Solar Variability on Northern Hemisphere Temperature Trends since the 19th Century. Earth-Science Reviews, 150, 409-452. https://doi.org/10.1016/j.earscirev.2015.08.010

[215] Hoyt, D.V. and Schatten, K.H. (1998) Group Sunspot Numbers: A New Solar Activity Reconstruction. Solar Physics, 181, 481-491.

https://doi.org/10.1023/A:1005056326158

[216] Scafetta, N. and Willson, R.C. (2014) ACRIM Total Solar Irradiance Satellite Composite Validation versus TSI Proxy Models. Astrophysics and Space Science, 350, 421-442. https://doi.org/10.1007/s10509-013-1775-9

[217] Soon, W.-H. (2009) Solar Arctic-Mediated Climate Variation on Multidecadal to Centennial Timescales: Empirical Evidence, Mechanistic Explanation, and Testable Consequences. Physical Geography, 30, 144-184. https://doi.org/10.2747/0272-3646.30.2.144

[218] Zhang, R. and Delworth, T.L. (2007) Impact of the Atlantic Multidecadal Oscillation on North Pacific Climate Variability. Geophysical Research Letters, 34, L23708. https://doi.org/10.1029/2007GL031601

[219] Soon, W. and Legates, D.R. (2013) Solar Irradiance Modulation of Equator-to-Pole (Arctic) Temperature Gradients: Empirical Evidence for Climate Variation on MultiDecadal Timescales. Journal of Atmospheric and Solar-Terrestrial Physics, 93, 45-56. https://doi.org/10.1016/j.jastp.2012.11.015

[220] Gleisner, H., Theijll, P., Christiansen, B. and Nielsen, J.K. (2017) Recent Warming Hiatus Dominated by Low-Latitude Temperature Trends in Surface and Troposphere Data. Geophysical Research Letters, 42, 510-517. https://doi.org/10.1002/2014GL062596

[221] Milankovitch, M. (1930) Mathematische Klimalehre und Astronomische Theorie der Klimaschwankungen. In: Handbuch der Klimalogie, Borntrager, Berlin, 1-A.

[222] Milankovitch, M. (1941) Kanon der Erdbestrahlungen und seine Anwendung auf das Eiszeitenproblem. Königlich Serbische Akademie, Belgrade, 633 p.

[223] Komitov, B., Sello, S., Duchlev, P., et al. (2015) Sub- and Quasi-Centurial Cycles in Solar and Geomagnetic Activity Data Series. Bulgarian Astronomical Journal, 25, 78.

[224] Cliver, E.M., Boriakoff, V. and Feynman, J. (1998) Solar Variability and Climate Change: Geomagnetic and aa Index and Global Surface Temperature. Geophysical Research Letters, 25, 1035-1038. https://doi.org/10.1029/98GL00499

[225] Babcock, H.W. (1961) The Topology of the Sun's Field and the Twenty-Two Years Cycle. The Astrophysical Journal, 139, 572-587. https://doi.org/10.1086/147060

[226] Duhau, S. and Chen, Ch.Y. (2002) The Sudden Increase of Solar and Geomagnetic Activity after 1923 as a Manifestation of a Non-Linear Solar Dynamo. Geophysical Research Letters, 29, 1628. https://doi.org/10.1029/2001GL013953 
[227] Lawrence, J.H. and Ruzmaikin, A.A. (1998) Transient Solar Influence on Terrestrial Temperature Fluctuations. Geophysical Research Letters, 25, 159-162. https://doi.org/10.1029/97GL03568

[228] Blanter, E.M., Le Mouël, M.-L., Shnirman, M.G. and Courtillot, V. (2014) Loss of Synchronization in the 27-Day Spectral Component of Geomagnetic Indices and Its Relationship with Solar Activity. Journal of Atmospheric and Solar-Terrestrial Physics, 117, 71-80. https://doi.org/10.1016/j.jastp.2014.04.002

[229] Hoyt, D.V. and Schatten, K.H. (1993) A Discussion of Plausible Solar Irradiance Variations 1700-1992. Journal of Geophysical Research, 98, 18895-18906. https://doi.org/10.1029/93JA01944

[230] Kuznetsova, T.V. (2020) Long-Term Spectral Components of Global North and South Hemisphere Temperatures over the Last Millennium and Solar-Lunar Forcing. https://www.researchgate.net/publication/339054668

[231] Le Mouël, J.-L., Lopes, F. and Courtillot, V. (2017) Identification of Gleissberg Cycles and a Rising Trend in a 315-Year-Long Series of Sunspot Numbers. Solar Physics, 292, 43. https://doi.org/10.1007/s11207-017-1067-6

[232] Lockwood, M., Rouillard, A.P. and Finch, I.D. (2009) The Rise and Fall of Open Solar Flux during the Current Grand Solar Maximum. Astrophysical Journal, 700, 937-944. https://doi.org/10.1088/0004-637X/700/2/937

[233] Alley, R.B. (2000) The Younger Dryas Cold Interval as Viewed from Central Greenland. Quaternary Science Reviews, 19, 213-226. https://doi.org/10.1016/S0277-3791(99)00062-1

[234] Alley, R.B. (2004) GISP2 Ice Core Temperature and Accumulation Data. IGBP PAGES/World Data Center for Paleoclimatology Data Contribution Series \#2004-013, NOAA/NGDC Paleoclimatology Program, Boulder.

[235] Humlum, O., Solheim, J.-E. and Stordahl, K. (2011) Identifying Natural Contributions to Late Holocene Climate Change. Global and Planetary Change, 79, 145-156. https://doi.org/10.1016/j.gloplacha.2011.09.005

[236] Lüdecke, H.J. and Weiss, C.-O. (2017) Harmonic Analysis of Worldwide Temperature Proxies for 2000 Years. The Open Atmospheric Science Journal, 11, 44-53. https://doi.org/10.2174/1874282301711010044

[237] Richards, M.T., Rogers, M.L. and Richards, D.St.P. (2009) Long-Term Variability in the Length of the Solar Cycle. Publications of the Astronomical Society of the Pacific, 121, 797-809. https://doi.org/10.1086/604667

[238] Solheim, J.-E. (2013) The Sunspot Cycle Length-Modulated by Planets? Pattern Recognition in Physics, 1, 159-164. https://doi.org/10.5194/prp-1-159-2013

[239] Solheim, J.-E. (2013) Signals from the Planets, via the Sun to the Earth. Pattern Recognition in Physics, 1, 177-184. https://doi.org/10.5194/prp-1-177-2013

[240] Maksimov, I.V. and Smirnov, N.P. (1965) A Contribution to the Study of Causes of Long-Period Variations in the Activity of the Gulf Stream. Oceanology, 5, 15-24.

[241] Maksimov, I.V. and Smirnov, N.P. (1967) A Long-Term Circumpolar Tide and Its Significance for the Circulation of Ocean and Atmosphere. Oceanology, 7, 173-178. (English Edition)

[242] Ogurtsov, M.G., Jungner, H., Kocharov, G.E., et al. (2003) On the Link between Northern Fennoscandan Climate and Length of the Quasi-Eleven-Years Cycle in Galactic Cosmic Ray Flux. Solar Physics, 218, 345-357. https://doi.org/10.1023/B:SOLA.0000013038.90223.09 
[243] Kasathkina, E.A., Shumilov, O.I., Timonen, M. and Kanatjev, A.G. (2018) Impact of Powerful Volcanic Eruptions and Solar Activity on the Climate above the Arctic Circle. Geophysica International, 57, 317-333. https://doi.org/10.22201/igeof.00167169p.2018.57.1.1823

[244] Scafetta, N. (2010) Empirical Evidence for a Celestial Origin of the Climate Oscillations and Its Implications. Journal of Atmospheric and Solar-Terrestrial Physics, 72, 951-970. https://doi.org/10.1016/j.jastp.2010.04.015

[245] Scafetta, N. (2016) High Resolution Coherence Analysis between Planetary and Climate Oscillations. Advances in Space Research, 57, 2121-2135. https://doi.org/10.1016/j.asr.2016.02.029

[246] Cionco, R.G., Valentini, J.E., Quaranta, N.V. and Soon, W.W.-H. (2018) Lunar Fingerprints in the Modulated Incoming Solar Radiation: In Situ Insolation and Latitudinal Insolation Gradients as Two Important Interpretative Metrics for Paleoclimatic Data Records and Theoretical Climate Modeling. New Astronomy, 58, 96-106. https://doi.org/10.1016/j.newast.2017.08.003

[247] Davis, B.A.S. and Brewer, S. (2009) Orbital Forcing and the Role of the Latitudinal Temperature/Isolation Gradient. Climate Dynamics, 32, 143-165. https://doi.org/10.1007/s00382-008-0480-9

[248] Hansen, J.M. (2015) Sea-Level Effects on NAO and AMO: Synchronization and Amplitude Locking by the Lunar Nodal Oscillation in the North Sea and Baltic Embayment. In: Mörner, N.-A., Ed., Planetary Influence on the Sun and the Earth, and a Modern Book-Burning, Nova Sci. Publ., New York, 51-70.

[249] Hansen, J.M., Aagaard, T. and Kuipers, A. (2015) Sea-Level Forcing by Synchronization of 56- and 74-Year Oscillations with Moon's Nodal Tide on the Northwest European Shelf (Eastern North Sea to Central Baltic Sea). Journal of Coastal Research, 31, 1041-1056. https://doi.org/10.2112/JCOASTRES-D-14-00204.1

[250] Yndestad, H. (2008) The Influence of Long Tides on Ecosystem Dynamics in the Barents Sea. Deep-Sea Research II, 56, 2108-2116. https://doi.org/10.1016/j.dsr2.2008.11.022

[251] Manley, G. (1974) Central England Temperatures: Monthly Means 1659 to 1973. Quarterly Journal of the Royal Meteorological Society, 100, 389-400. https://doi.org/10.1002/qj.49710042511

[252] Dawson, A.G., Lome, E., Mayewski, P.L., et al. (2003) Late-Holocene North Atlantic Climate "Seesaws" Storminess Changes and Greenland Ice Sheet (GISP2) Palaeoclimates. The Holocene, 13, 381-392. https://doi.org/10.1191/0959683603hl631rp

[253] Dawson, A., Elliott, L., Noone, S., et al. (2004) Historical Storminess and Climate "See-Saws" in the North Atlantic Region. Marine Geology, 210, 247-259. https://doi.org/10.1016/j.margeo.2004.05.011

[254] Svensmark, H., Enghoff, M. and Pepke Pedersen, J.O. (2013) Response of Cloud Condensation Nuclei $(>50 \mathrm{~nm})$ to Changes in Ion-Nucleation. Physics Letters $A$, 377, 2343-2347. https://doi.org/10.1016/j.physleta.2013.07.004

[255] Mörner, N.-A. (1984) Planetary, Solar, Atmospheric, Hydrospheric and Endogene Processes as Origin of Climatic Changes on the Earth. In: Mörner, N.-A. and Karlén, W., Eds., Climate Change on a Yearly to Millennial Basis, Wiley \& Sons, Christchurch, 483-507. https://doi.org/10.1007/978-94-015-7692-5_48

[256] Wanner, H., Brönnimann, S., Casty, C., et al. (2001) North Atlantic Oscillation-Concept and Studies. Surveys in Geophysics, 22, 321-382.

https://doi.org/10.1023/A:1014217317898 
[257] Pinto, J.G. and Raible, C.C. (2012) Past and Recent Changes in the North Atlantic Oscillation. WIREs Climate Change, 3, 79-90. https://doi.org/10.1002/wcc.150

[258] Boström, P. (2012) NAO Index: An Extreme Pressure Approach. Thesis No. 283, Department of Earth Sciences, Uppsala University, Uppsala.

[259] Yndestad, H. (2004) The Lunar Nodal Cycle Influence on the Barents Sea. PhD Thesis, Fakultet for samfunnsvitenskap og teknologiledelse Institutt for industriell økonomi og teknologiledelse, Norges teknisk-naturvitenskapelige universitet, NTNU Trondheim.

[260] Yndestad, H. (2004) The Lunar Nodal Cycle Influence on the Barents Sea. The Response of the Ecosystems of the Nordic Sea to Climate Change. PhD Thesis, Department of Industrial Ecology and Technology Management, Norwegian University of Science and Technology, Trondheim.

[261] Wyatt, M.G. (2012) A Multidecadal Climate Signal Propagating across the Northern Hemisphere through Indices of a Synchronized Network. PhD Dissertation, University of Colorado, Boulder, $220 \mathrm{p}$.

[262] Mazzarella, A. (2007) The 60-Year Solar Modulation of Global Air Temperature: The Earth's Rotation and Atmospheric Circulation Connection. Theoretical and Applied Climatology, 88, 193-199. https://doi.org/10.1007/s00704-005-0219-z

[263] Luterbacher, J., Xoplaki, E., Dietrich, D., et al. (2002) Extending North Atlantic Oscillation Reconstructions Back to 1500. Atmospheric Science Letters, 2, 114-124. https://doi.org/10.1006/asle.2001.0044

[264] Scafetta, N. (2013) Solar and Planetary Oscillation Control on Climate Change: Hind-Cast, Forecast and a Comparison with CMIP5 GCMS. Energy \& Environment, 24, 455-496. https://doi.org/10.1260/0958-305X.24.3-4.455

[265] Humlum, O. (2013) Kommentar til FNs klimapalels sammendrag. Report to Klimarealistene. http://www.klimarealistene.com

[266] Mazzarella, A. (2008) Solar Forcing of Changes in Atmospheric Circulation, Earth's Rate of Rotation and Climate. The Open Atmospheric Science Journal, 2, 181-184. https://doi.org/10.2174/1874282300802010181

[267] Braginskiy, S.I. (1982) Analytical Description of the Secular Variations of the Geomagnetic Field and the Rate of Rotation of the Earth. Geomagnetism Aeronomy, 22, 88-94.

[268] Roberts, P.H., Yu, Z.J. and Russell, C.T. (2007) On the 60-Year Signal from the Core. Geophysical \& Astrophysical Fluid Dynamics, 101, 11-35. https://doi.org/10.1080/03091920601083820

[269] Bucha, V. (1983) Direct Relations between Solar Activity and Atmospheric Circulation, Its Effects on Weather and Climate. Studia Geophysica et Geodetica, 27, 19-45. https://doi.org/10.1007/BF01630744

[270] Corbyn, P. (2019) Climate Change Emergency Truth Class-Talk and PowerPoint. http://www.WeatherAction.com

[271] Chambers, D.P., Merrifield, M.A. and Nerem, R.S. (2002) Is There a 60-Year Oscillation in Global Mean Sea Level. Geophysical Research Letters, 39, L18607. https://doi.org/10.1029/2012GL052885

[272] Parker, A. (2013) Natural Oscillations and Trends in Long-Term Tide Gauge Records from the Pacific. Pattern Recognition in Physics, 1, 11-23. https://doi.org/10.5194/prp-1-11-2013

[273] Parker, A. (2013) Minimum 60 Years of Recording Are Needed to Compute the Sea Level Rate of Rise in the Western South Pacific. Nonlinear Engineering, 3, 1-10. https://doi.org/10.1515/nleng-2013-0011 
[274] Mörner, N.-A. (2013) Planetary Beat and Solar-Terrestrial Responses. Pattern Recognition in Physics, 1, 107-116. https://doi.org/10.5194/prp-1-107-2013

[275] Abdussamatov, H. (2016) The New Little Ice Age Has Started. In: Easterbrook, D.J., Ed., Evidence-Based Climate Change, Second Edition, Elsevier, Amsterdam, 307-328. https://doi.org/10.1016/B978-0-12-804588-6.00017-3

[276] Shepherd, S.I., Zharkov, S.I. and Zharkova, V.V. (2014) Prediction of Solar Activity from Solar Background Magnetic Field Variations in Cycles 21-23. Astrophysics Journal, 795, 46. https://doi.org/10.1088/0004-637X/795/1/46 


\section{Appendix 1 (by Nils-Axel Mörner)}

\section{The "stadium wave wheel" mechanism in need of external forcing}

Wyatt [1] and Wyatt and Curry [2] have presented a quite remarkable "Stadium-wave" mechanism of a special and temporal wave of 4 segments propagating across the Northern Hemisphere activating a network of synchronized climate variables. They identified four temporal groups (I - IV) changing between negative and positive phases. It offers means of synchronization and feedback coupling between ocean, ice and wind factors, but it lacks driving input energy forces. Therefore, I analysed the system in view of our paper on the changes in Arctic sea ice edge positions during the last 440 years with respect to planetary-solar modulation and Gulf Stream beat.

Wyatt [1] proposed that the variables of the Northern Hemisphere surface temperature (NHT), the Atlantic Multidecadal Oscillation (AMO), the North Atlantic Oscillation (NAO), the El Nino-Southern Oscillation index (NINO3.4), the North Pacific Oscillation (NPO), the Pacific Decadal Oscillation (PDO), the Aleutian Low Pressure Index (ALPI), and the index of Atmospheric-Mass-Transfer anomalies (AT) could be combined into a logical system of a wave propagating around the Northern Hemisphere in a manner resembling a stadium wave of applauding athletes at sport events. This initiated the "Stadium Wave" Wheel theory of Wyatt and Curry [2]. Wyatt [1] "did not assign an exact period to the signal; rather, the signal is described as secularly varying, with an apparent 64 -year period during the $20^{\text {th }}$ century" (quot. [2]). Therefore, I think, we are allowed to elaborate with the timing of their four (I-IV) "temporal groups" as done in Figure 23 and Figure 24.

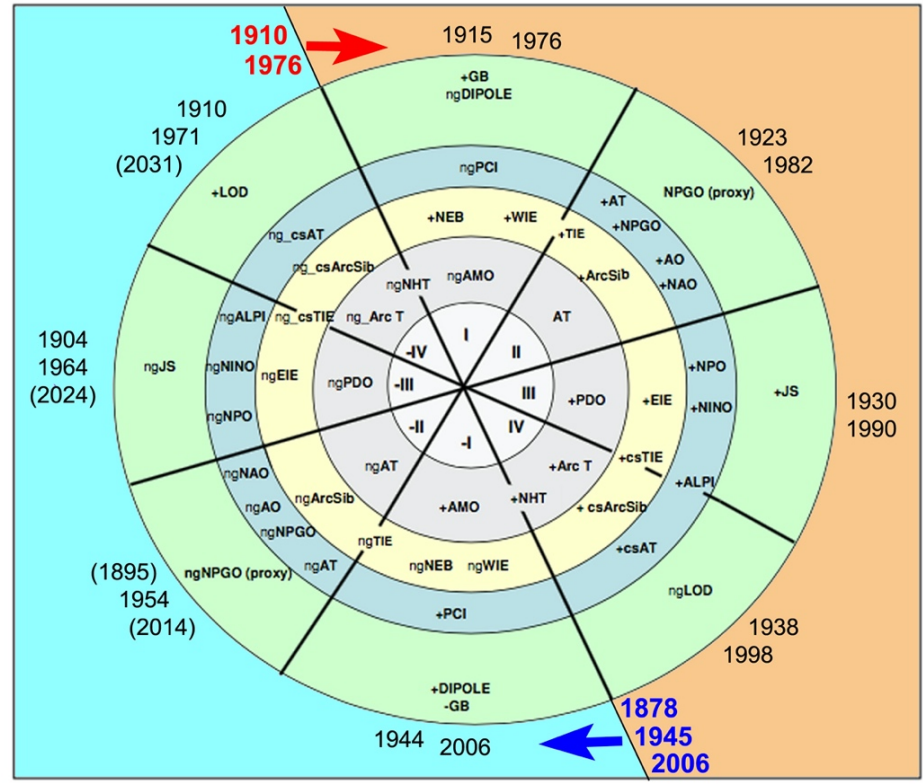

Figure 23. The "stadium wave wheel" [2] here divided into two halves; a warm half beginning 1910 and 1976 and a cold half beginning 1878, 1945 and 2006 (for explanations of acronyms [2]). 


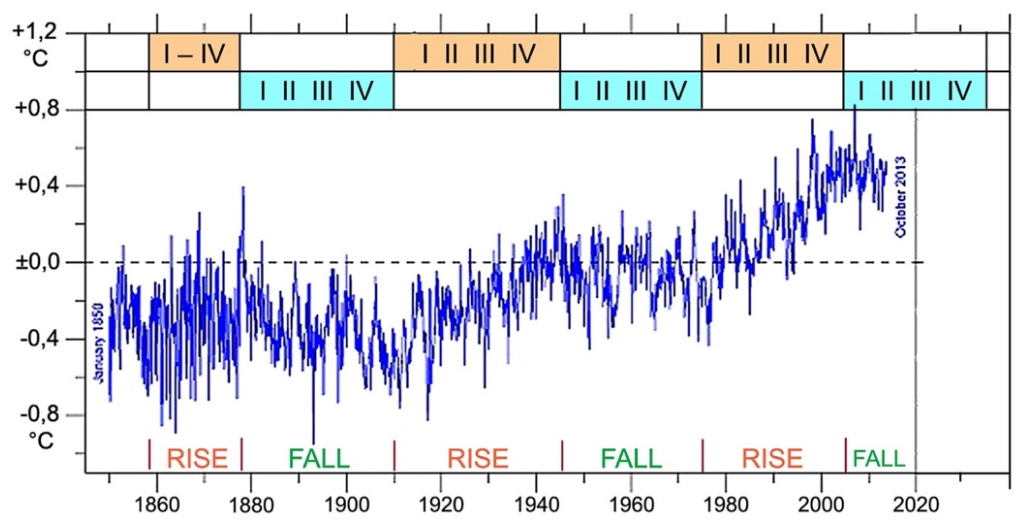

Figure 24. The warm segments I-IV (orange) and cold segments I-IV (blue) in the "stadium wave wheel" [2] compared to their probable positions with respect to the global temperature curve [3] [4] and its division in periods of 30 years rises and falls indicating a 60 -yrs external driving force [5].

In Figure 23, I have simply divided the "stadium wave wheel" of Wyatt and Curry [2] into two halves; a warm half beginning 1910 and 1976 and a cold half beginning 1878, 1945 and 2006 as given the main global temperature curve in Figure 24.

In Figure 24, we compare the temporal zonation given by Wyatt and Curry [2] and the main global temperature record of the last 150 years [3] [4] [5]. The similarity is clear. There is an alternation between warm and cold periods of a duration of about 30 years; i.e. a full cycle of 60 years. It predicts a cooling from 2006 to 2036. The dominant 60-yr cycle is indicative of an external force of planetary-solar origin.

I therefore propose that the stadium wave mechanism by Wyatt and Curry [2] of a number of inter-connected internal factors of coupling and feedback, in fact, is ultimately driven by external forces going back to a planetary beat (Figure 9 in the main paper). There are strong arguments for seeking a primary forcing of $\mathrm{AO}$ in geomagnetic changes [6], and of AMO, NAO and PDO in external rotation [7] [8] [9].

\section{References}

[1] Wyatt, M.G. (2012) A Multidecadal Climate Signal Propagating across the Northern Hemisphere through Indices of a Synchronized Network. PhD Dissertation, University of Colorado, Boulder, $220 \mathrm{p}$.

[2] Wyatt, M.G. and Curry, J.A. (2014) Role of Eurasian Arctic Shelf Sea Ice on a Secularly Varying Hemispheric Climate Signal during the 20th Century. Climate Dynamics, 42, 2763-2782. https://doi.org/10.1007/s00382-013-1950-2

[3] Humlum, O. (2013) Kommentar til FNs klimapanels sammendrag. Report to Klimarealistene. http://www.klimarealistene.com

[4] Humlum, O. (2018) State of the Climate 2017. GWPF, 30, 1-56.

[5] Mörner, N.-A. (2018) Anthropogenic Global Warming (AGW) or Natural Global Warming (NGW). Voice of the Publisher, 4, 51-59. https://doi.org/10.4236/vp.2018.44005 
[6] Bucha, V. (1984) Mechanism for Linking Solar Activity to Weather-Scale Effects, Climate Changes and Glaciations in the Northern Hemisphere. In Mörner, N. A. and Karlén, W. Eds., Climate Changes on a Yearly to Millennial Basis, Springer, Dordrecht, 415-448. https://doi.org/10.1007/978-94-015-7692-5_45

[7] Mörner, N.-A. (1996) Global Change and Interaction of Earth Rotation, Ocean Circulation and Paleoclimate. The Anais da Academia Brasileira de Ciências, 68, 77-94.

[8] Mörner, N.-A. (2010) Solar Minima, Earth's Rotation and Little Ice Ages in the Past and in the Future: The North Atlantic-European Case. Global and Planetary Change, 72, 282-293. https://doi.org/10.1016/j.gloplacha.2010.01.004

[9] Wilson, I.R.G. (2011) Are Changes in the Earth's Rotation Rate Externally Driven and Do They Affect Climate? The General Science Journal, 3812, 1-31. 


\section{Appendix 2 (by Nils-Axel Mörner)}

\section{The Gulf Stream Beat Theory: Origin and Perspectives}

The close correlation observed among the changes in Gulf Stream beat [1] [2], the changes in a combined curve of the Gleissberg and de Vries cycles (Fig. 5 in [2]) and the observed changes in atmospheric ${ }^{14} \mathrm{C}$ production ([3] [4]; Figure 4), which is a measure of the strength of the Earth's geomagnetic shielding capacity, provide a chain of facts indicating that solar variability driven by planetary beat controls the Earth's geomagnetic field strength driving the latitudinal beat of the Gulf Stream. Additional data [5] indicate that there is a close correlation between Gulf Stream beat and Earth's rate of rotation. The Solar Wind changes observed (Figure 21; [6]) are indicative of the solar-terrestrial interaction [7] [8].

This implies that we see the following linkage between solar variability as seen in the alternation between Grand Solar Maxima and Minima), Earth's rotation and the beat of the distribution of water masses by the Gulf Stream (Figure 25).

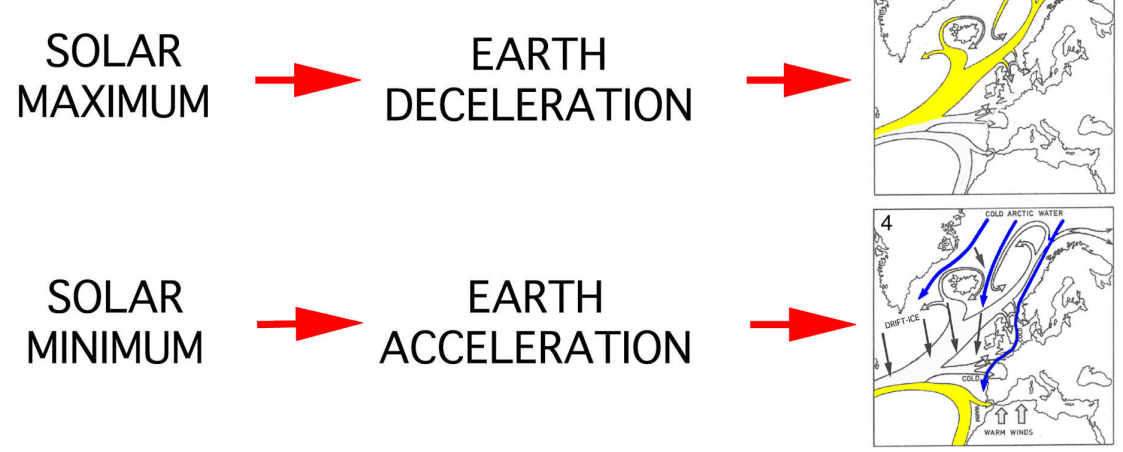

Figure 25. Relations among solar cycles, Earth's rate of rotation and the observed changes in the ocean circulation in the North Atlantic [1] [2].

Over the last 800 years the Gulf Stream has switch between circulation patterns of type-a (at Grand Solar Maxima) and type-c (at Grand Solar Minima) in Figure 3 , in the following way (Figure 26 from [7]):

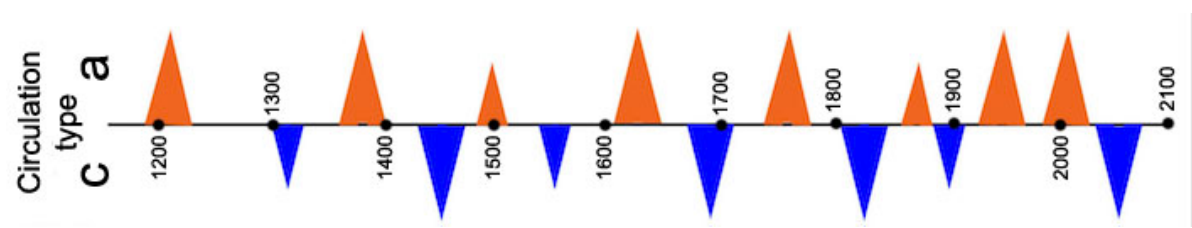

Figure 26. Changes main Gulf Stream circulation patterns during the last 800 years between type-a (orange wedges upwards) and type-c (blue wedges downwards) (from [8]).

The changes in Gulf Stream circulation pattern (Figure 26) fit very well with a curve combining the Gleissberg 84 yrs cycle and the De Vries 240 yrs cycle (from [2]) indicating correlation between solar variability and Gulf Stream beat (Figure 27). 


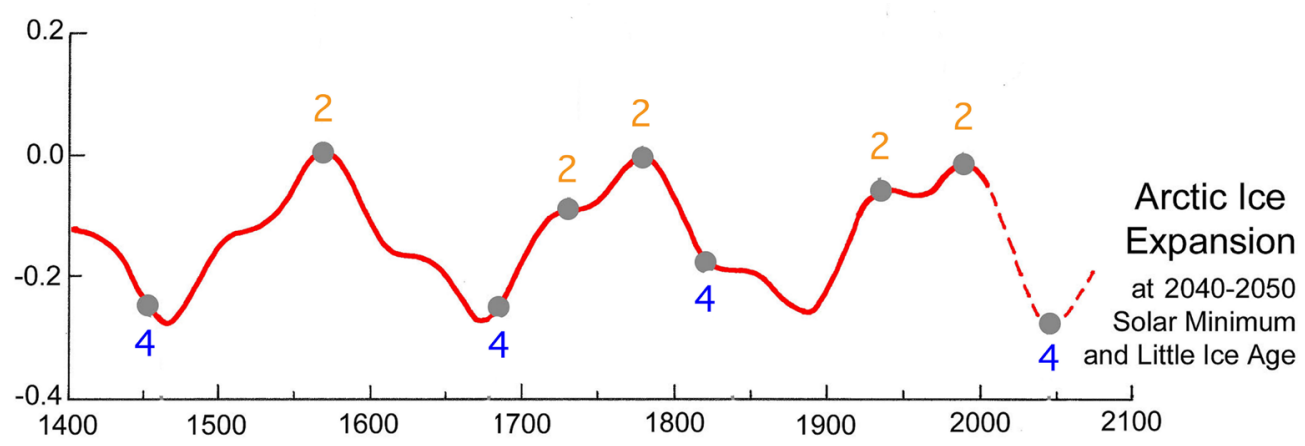

Figure 27. Cyclic phasing of the combined "Gleisberg" and De Vries Cycles over the last 600 years giving a new Solar Minimum at about 2040-2050 (from [2]). Observed periods of type-a and type-c Gulf Stream circulation patterns are marked with dots and label 2 (type-a) and 4 (type-c) according to Mörner [1]. Vertical scale gives temperature in centigrade.

The changes in Gulf Stream beat (Figure 26) also correlates well with recorded changes in ${ }^{14} \mathrm{C}$ production, indicating a correlation between changes in the Earth's shielding strength and the ocean circulation changes (Figure 28).
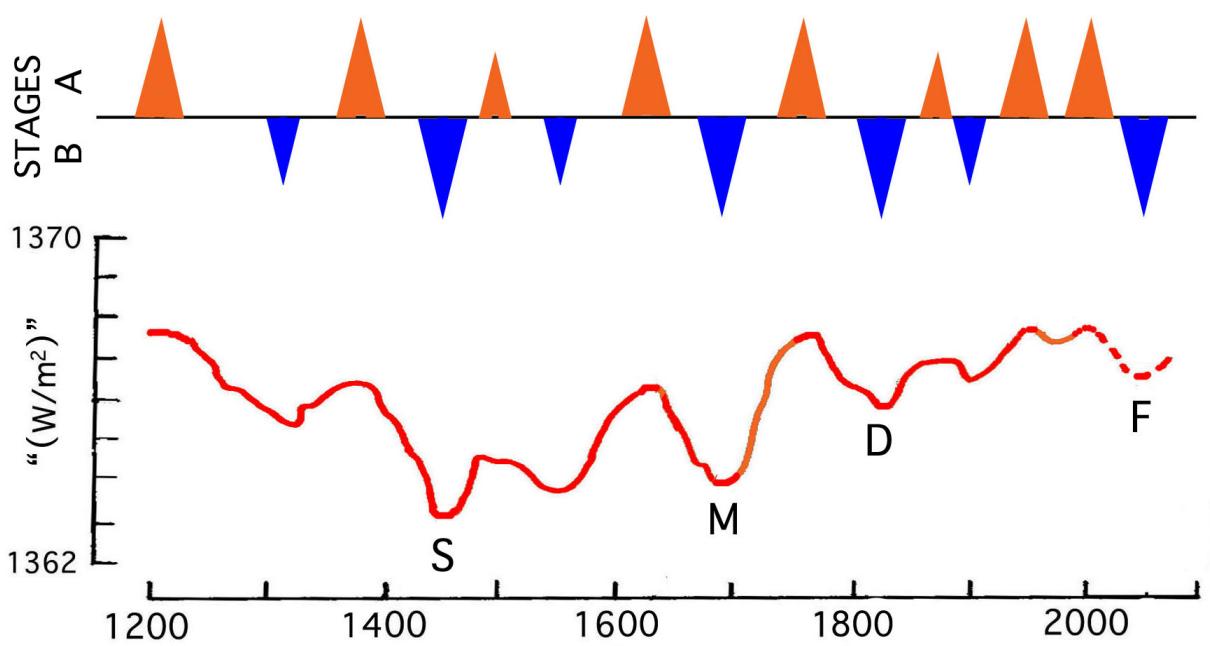

Figure 28. Comparison between Gulf Stream circulation patterns according to Figure 27 (above) and a curve of ${ }^{14} \mathrm{C}$ production (below) by Bard et al. [9] termed "solar irradiance" though it, in fact, is a curve of geomagnetic shielding primarily controlled by the Solar Wind effects [1] [2] [7] [8]. S, M, D and F stands for Spörer, Maunder, Dalton and Future Grand Solar Minima. The corresponding alternation between type-a (orange wedges) and type-c (blue wedges) North Atlantic circulation is given in the top graph (cf. Figure 26). Figure 30 gives an update version of the geomagnetic shielding during the last 450 years and Figure 4 covers the last 1000 years.

In 1996, I suddenly realised that the Earth's rate of rotation (Figure 29) was strongly controlled by external changes in the Earth's geomagnetic shielding strength due to interaction with the Solar Wind [5]. The external forcing has later been confirmed by Mazzarella [10], and Mazzarella and Scafetta [11]. Figure 29 record resemble the Solar Wind record (Figure 21) in showing long cycles during the $17^{\text {th }}$ and $18^{\text {th }}$ centuries and a dominance of a 60 yrs cycle for the last 200 years. 


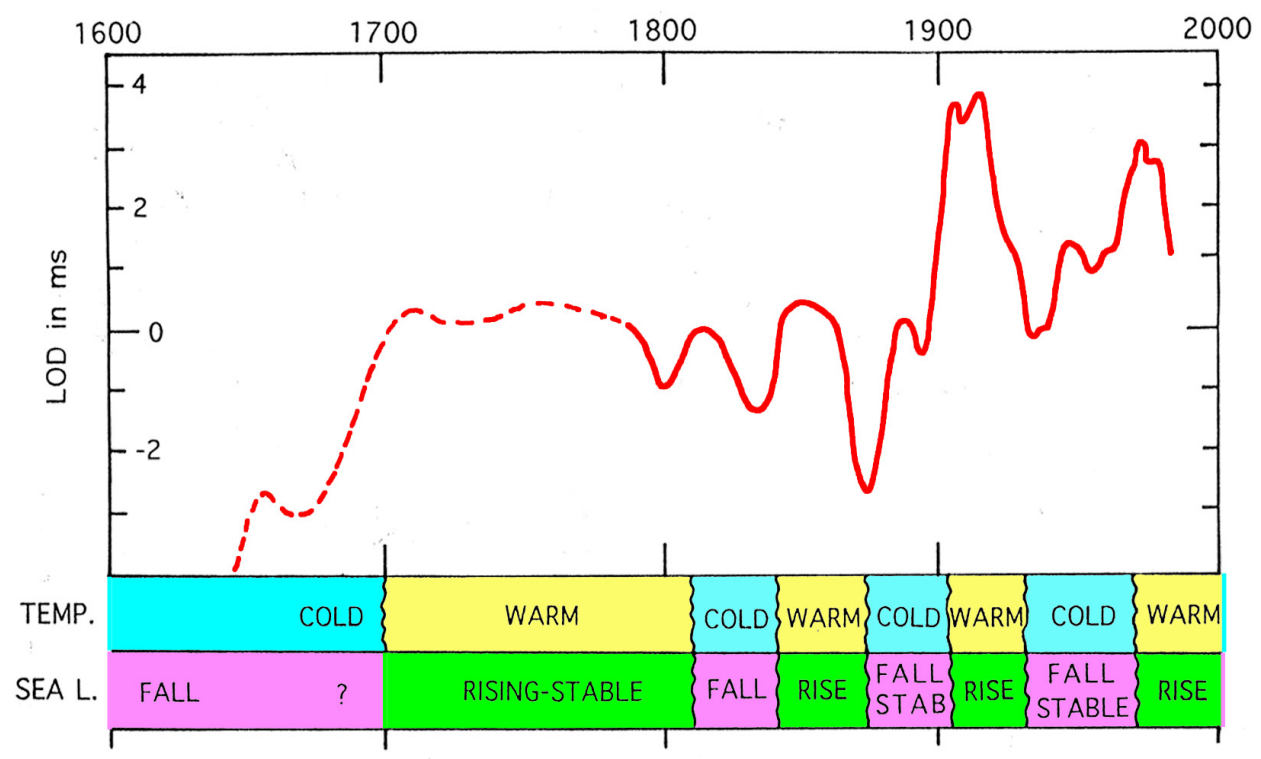

Figure 29. The changes in LOD (down implies acceleration and up deceleration) and corresponding changes in temperature and sea level in the Northwest European region (from [5]). The correlations seem good and lend support to the rotational/circulation theory proposed [12] [13]. The changes in LOD as well as in temperature and sea level follow a cyclic pattern: centennial for the first 200 years and of an about 60 yrs cyclicity for the last 200 years. The PDO cycle shows a similar pattern with a cyclicity of about $\sim 56$ yr (1921-1977 and 1942-1998).

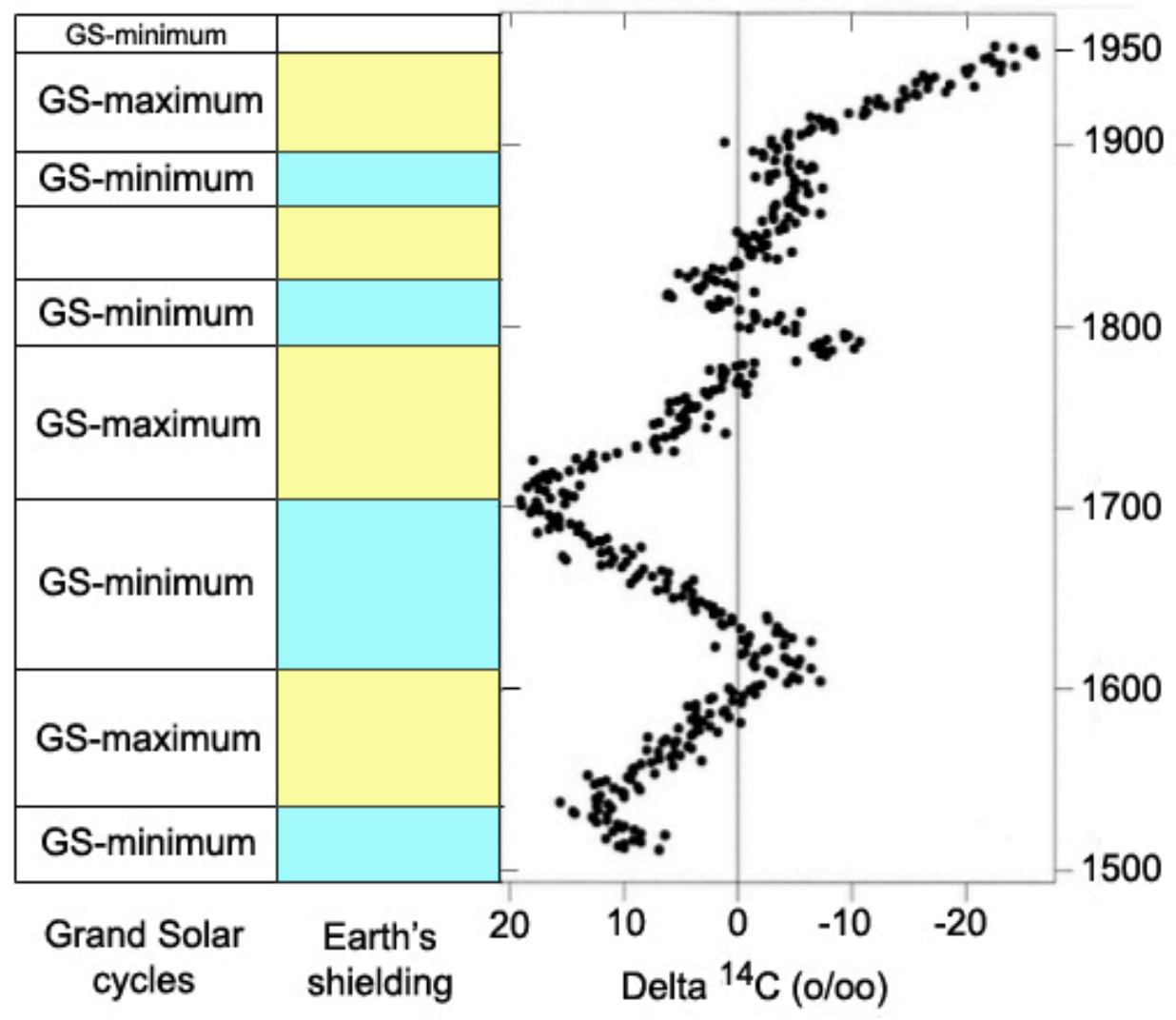

Figure 30. Delta ${ }^{14} \mathrm{C}$ variations [3], with interpretations in terms of Grand Solar Maxima/Minima and terrestrial warm/cold phases (also type-a/type-c Atlantic circulation). 
Figure 30 (from [3]) provides a very sharp and clear picture of the changes in atmospheric ${ }^{14} \mathrm{C}$ production since $\mathrm{AD} 1500$ (a longer record is given Figure 4). Whilst the cycles from 1450 up to 1790 are in the order of 80 - 90 years, the cycles after 1790 are in the order of 60 years. This is in agreement with the LOD record (Figure 29) and the Solar Wind record (Figure 21). It also agrees with the Gulf Stream changes between type-a and type-c circulation patterns.

In conclusion, this means that we see the following chain of cause-and-effect behind the observed cyclic pattern in changes of North Atlantic circulation and its stepwise origin in causal changes in rotation, shielding, solar wind intensity, solar variability and planetary beat as shown in Figure 31 (cf. Figure 9):

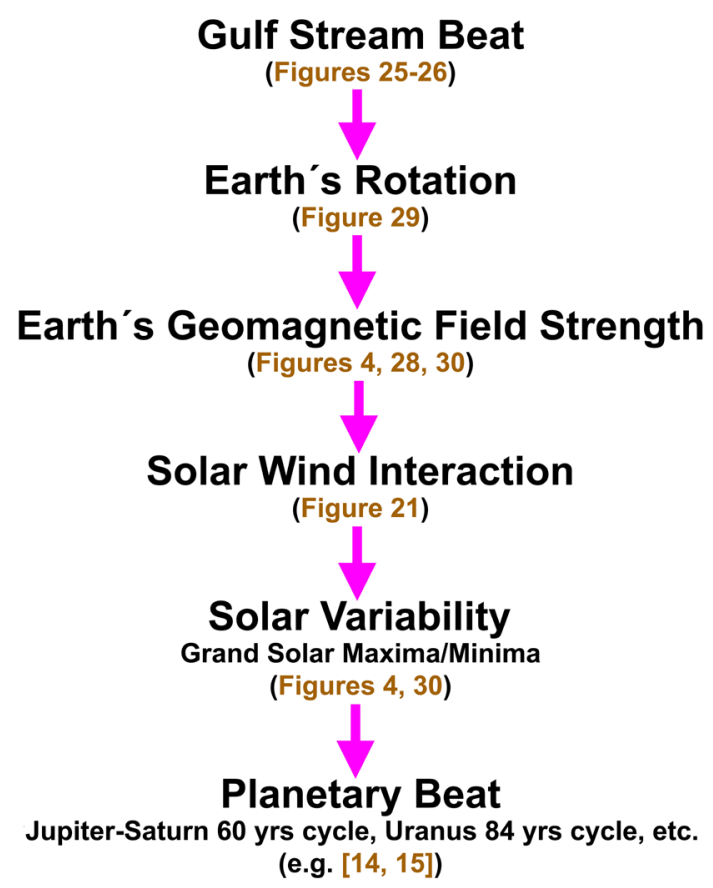

Figure 31. Chain of cause-and-effects from Gulf Stream Beat back to its ultimate origin in Planetary Beat (cf. Figure 9) [14] [15].

\section{References}

[1] Mörner, N.-A. (2010) Solar Minima, Earth's Rotation and Little Ice Ages in the Past and in the Future: The North Atlantic-European Case. Global and Planetary Change, 72, 282-293. https://doi.org/10.1016/j.gloplacha.2010.01.004

[2] Mörner, N.-A. (2011) Arctic Environment by the Middle of This Century. Earth \& Environment, 22, 207-218. https://doi.org/10.1260/0958-305X.22.3.207

[3] Sekonya, K.G. (2017) Development of a 6 Mv Tandem Accelerator Mass Spectrometry Facility and Its Applications. PhD Thesis at the Faculty of Science, University of the Witwatersrand, Johannesburg, $197 \mathrm{p}$.

[4] Dergachev, V.A. and Vasiliev, S.S. (2019) Long-Term Changes in the Concentration of Radiocarbon and the Nature of the Hallstatt Cycle. Journal of Atmospheric and Solar-Terrestrial Physics, 182, 10-24. https://doi.org/10.1016/j.jastp.2018.10.005

[5] Mörner, N.-A. (1996) Global Change and Interaction of Earth Rotation, Ocean Circulation and Paleoclimate. The Anais da Academia Brasileira de Ciências, 68, 77-94. 
[6] Owens, M.J., Lockwood, M. and Riley, P. (2017) Global Solar Wind Variations over the Last Four Centuries. Scientific Reports, 7, Article No. 41548. https://doi.org/10.1038/srep41548

[7] Mörner, N.-A. (2012) Planetary Beat, Solar Wind and Terrestrial Climate. In: Escaropa, C.D. and Berós Cruz, A.F., Eds., Solar Wind: Emission, Technologies and Impacts, Nova Sci. Publ., New York, 47-66.

[8] Mörner, N.-A. (2013) Solar Wind, Earth's Rotation and Changes in Terrestrial Climate. Physical Review \& Research International, 3, 117-136.

[9] Bard, E., Raisbeck, G., Yiou, F. and Jouzel, J. (2000) Solar Irradiance during the Last 1200 Years Based on Cosmogenic Nuclides. Tellus, 52B, 985-992. https://doi.org/10.3402/tellusb.v52i3.17080

[10] Mazzarella, A. (2008) Solar Forcing of Changes in Atmospheric Circulation, Earth's Rate of Rotation and Climate. The Open Atmospheric Science Journal, 2, 181-184. https://doi.org/10.2174/1874282300802010181

[11] Mazzarella, A. and Scafetta, N. (2018) The Little Ice Age Was 1-0-1.5 ${ }^{\circ} \mathrm{C}$ Cooler That Current Warm Period According to LOD and NAO. Climate Dynamics. https://doi.org/10.1007/s00382-018-4122-6

[12] Mörner, N.-A. (1988) Terrestrial Variations within Given Energy, Mass and Momentum Budgets; Paleoclimate, Sea Level, Paleomagnetism, Differential Rotation and Geodynamics. In: Stephenson, F.R. and Wolfendale, A.W., Eds., Secular Solar and Geomagnetic Variations in the Last 10,000 Years, Kluwer Academic Publishers, Dordrecht, 455-478.

https://doi.org/10.1007/978-94-009-3011-7_29

[13] Mörner, N.-A. (1989) Changes in the Earth's Rate of Rotation on an El Niño to Century Basis. In: Lowes, F.J., et al., Eds., Geomagnetism and Paleomanetism, Kluwer Academic Publishers, Dordrecht, 45-53. https://doi.org/10.1007/978-94-009-0905-2_4

[14] Scafetta, N. (2010) Empirical Evidence for a Celestial Origin of the Climate Oscillations and Its Implications. Journal of Atmospheric and Solar-Terrestrial Physics, 72 , 951-970. https://doi.org/10.1016/j.jastp.2010.04.015

[15] Yndestad, H. and Solheim, J.-E. (2017) The Influence of Solar System Oscillation on the Variability of the Total Solar Irradiance. New Astronomy, 51, 135-152. https://doi.org/10.1016/j.newast.2016.08.020 